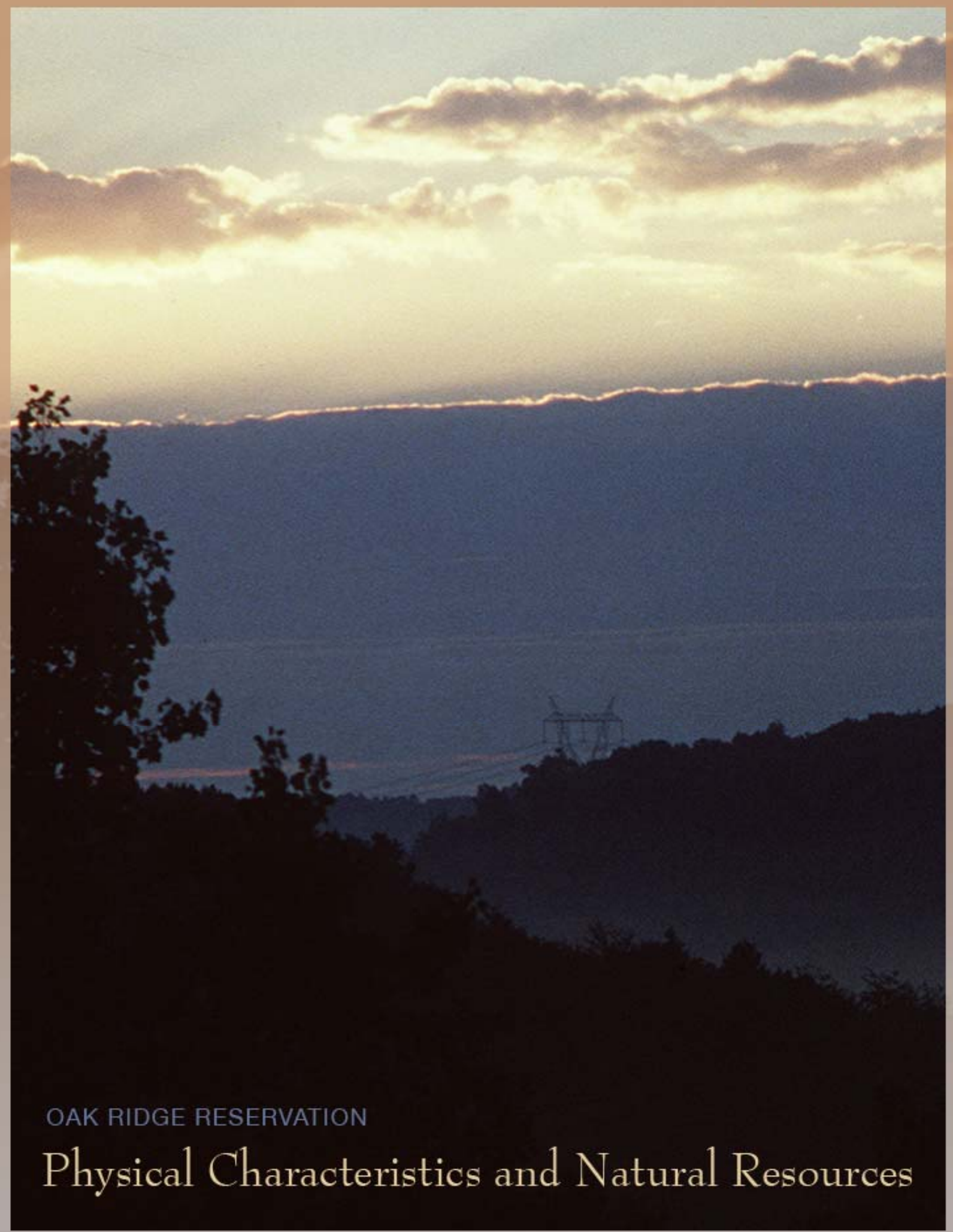

September 2006

PATRICIA DREYER PARR and JOAN F. HUGHES

Oak Ridge National Laboratory 


\section{DOCUMENT AVAILABILITY}

Reports produced after January 1, 1996, are generally available free via the U.S. Department of Energy (DOE) Information Bridge.

Web site http://www.osti.gov/bridge

Reports produced before January 1, 1996, may be purchased by members of the public from the following source.

National Technical Information Service

5285 Port Royal Road

Springfield, VA 22161

Telephone 703-605-6000 (1-800-553-6847)

TDD 703-487-4639

Fax 703-605-6900

E-mail info@ntis.gov

Web site http://www.ntis.gov/support/ordernowabout.htm

Reports are available to DOE employees, DOE contractors, Energy Technology Data Exchange (ETDE) representatives, and International Nuclear Information System (INIS) representatives from the following source.

Office of Scientific and Technical Information

P.O. Box 62

Oak Ridge, TN 37831

Telephone 865-576-8401

Fax 865-576-5728

E-mail reports@osti.gov

Web site http://www.osti.gov/contact.html

This report was prepared as an account of work sponsored by an agency of the United States Government. Neither the United States Government nor any agency thereof, nor any of their employees, makes any warranty, express or implied, or assumes any legal liability or responsibility for the accuracy, completeness, or usefulness of any information, apparatus, product, or process disclosed, or represents that its use would not infringe privately owned rights. Reference herein to any specific commercial product, process, or service by trade name, trademark, manufacturer, or otherwise, does not necessarily constitute or imply its endorsement, recommendation, or favoring by the United States Government or any agency thereof. The views and opinions of authors expressed herein do not necessarily state or reflect those of the United States Government or any agency thereof. 


\title{
OAK RIDGE RESERVATION PHYSICAL CHARACTERISTICS AND NATURAL RESOURCES
}

\author{
Patricia Dreyer Parr \\ Facilities and Operations Directorate \\ Joan F. Hughes \\ Environmental Protection and Waste Services Division
}

September 2006

\author{
Prepared by \\ OAK RIDGE NATIONAL LABORATORY \\ P.O. Box 2008 \\ Oak Ridge, Tennessee 37831-6283 \\ managed by \\ UT-BATTELLE, LLC \\ for the \\ U.S. DEPARTMENT OF ENERGY \\ under contract DE-AC05-00OR22725
}





\section{CONTENTS}

Page

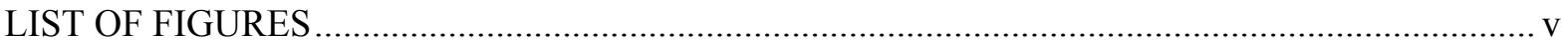

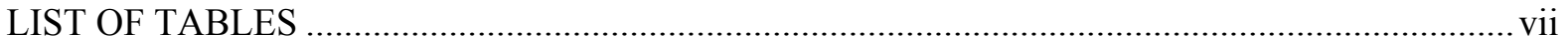

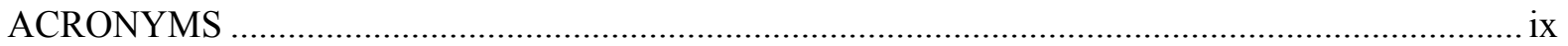

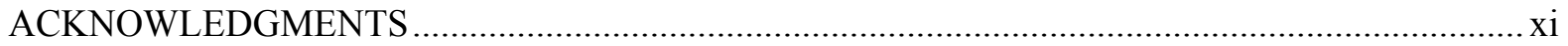

1. OAK RIDGE RESERVATION PHYSICAL CHARACTERISTICS AND NATURAL

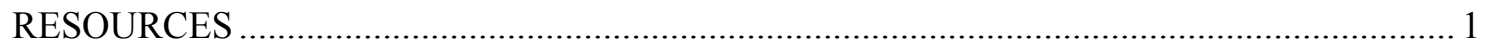

2. CLIMATE …

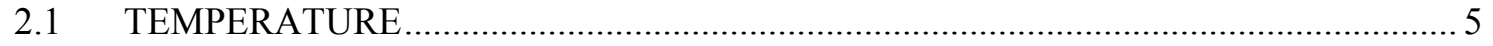

2.2 WINDS .

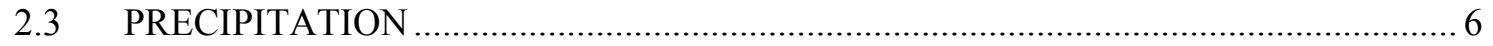

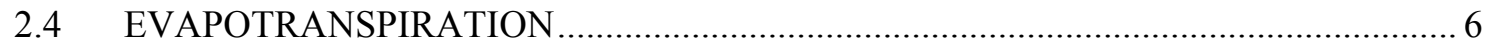

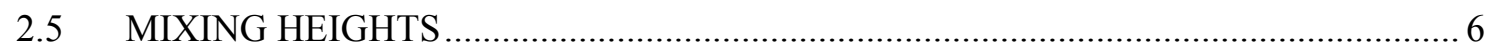

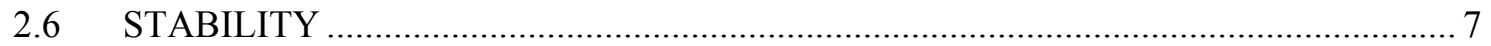

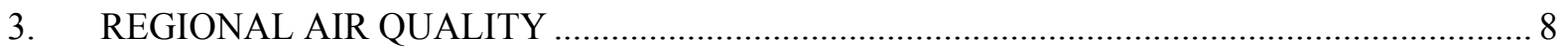

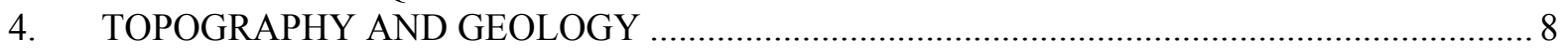

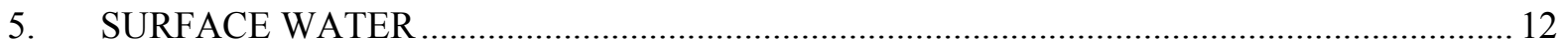

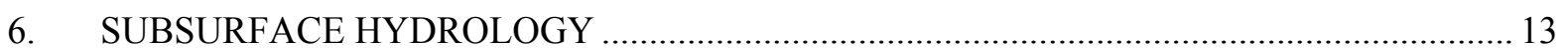

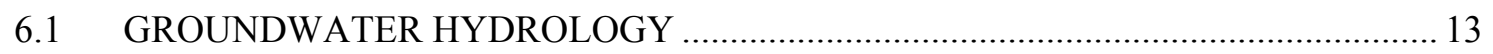

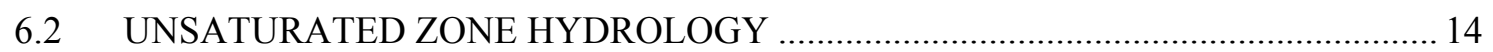

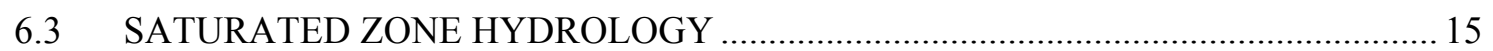

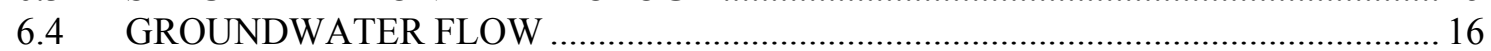

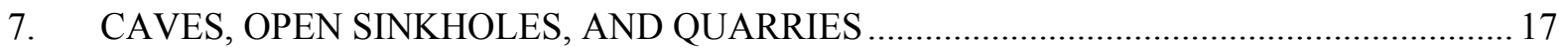

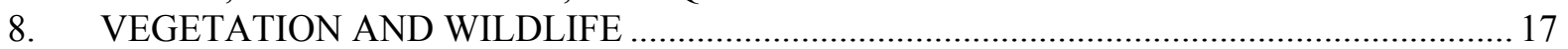

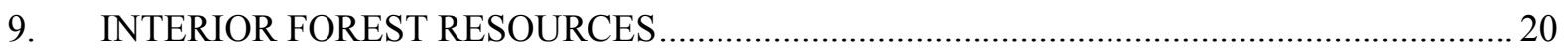

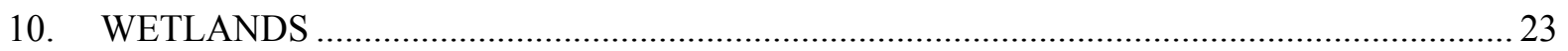

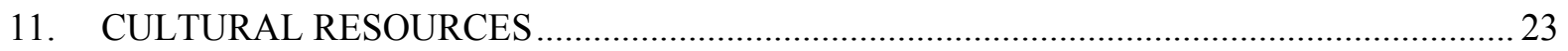

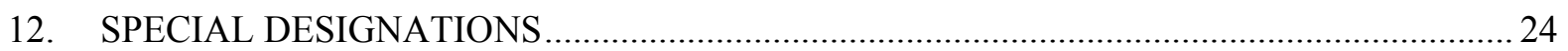

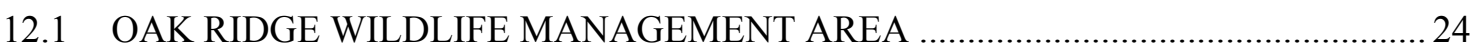

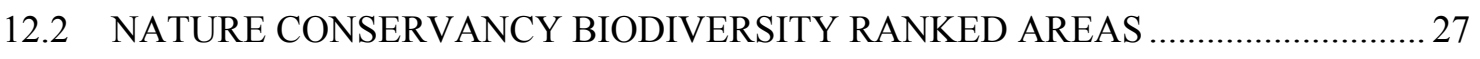

12.3 NATURE CONSERVANCY LANDSCAPE COMPLEXES ...................................... 27

12.4 RESEARCH PARK ENDANGERED SPECIES HABITATS (NATURAL

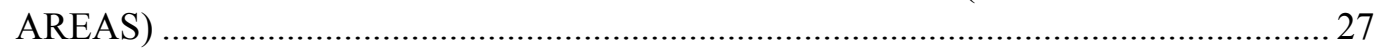

12.5 RESEARCH PARK ENDANGERED SPECIES POTENTIAL HABITATS

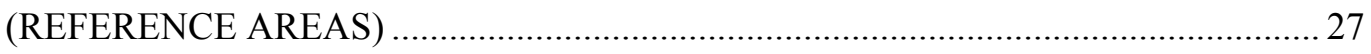

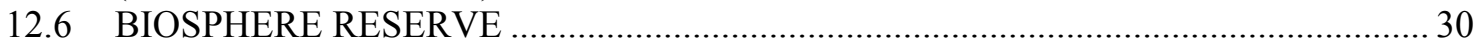

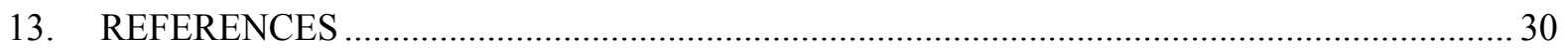

\section{APPENDIXES}

A PLANTS FOUND ON THE OAK RIDGE RESERVATION …............................................ A-1

B ANIMALS FOUND ON THE OAK RIDGE RESERVATION ……................................... B-1 



\section{LIST OF FIGURES}

Figure

Page

1

2

3

4

5

6

7

8

9

10

11

12

13

ORR biologically significant areas, sinks, and springs

ORR's position within the physiographic provinces of Tennessee

Regional land-cover map prepared from a July 3, 2006, Landsat Thematic Mapper

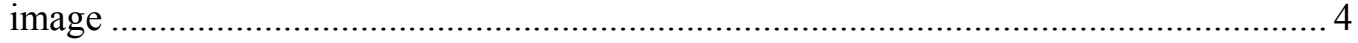

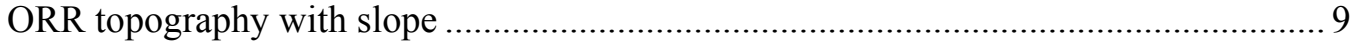

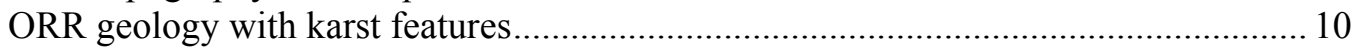

Water, wetlands, floodplains, and watersheds on the ORR ....................................... 11

Relationship between stormflow zone, water table, and unsaturated and saturated

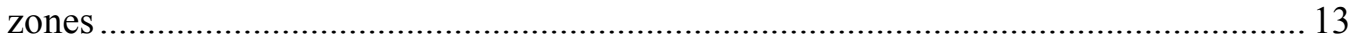

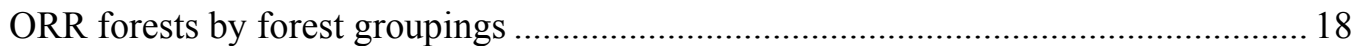

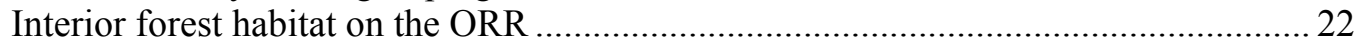

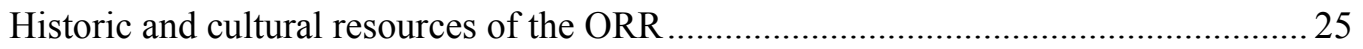

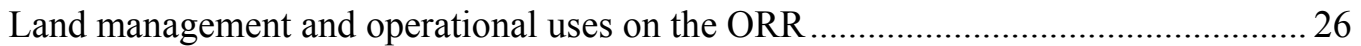

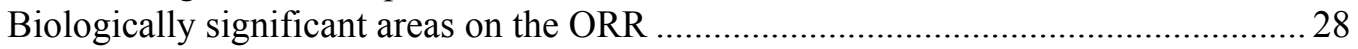

Confirmed and potential habitats for rare plants and wildlife on the ORR ..................29 



\section{LIST OF TABLES}

Table

Page

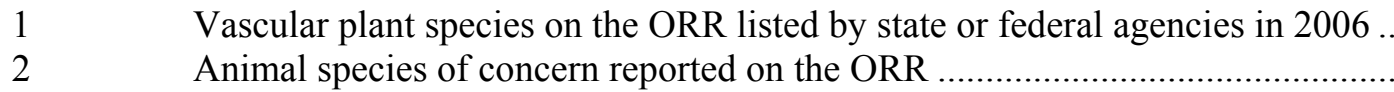

19 



\section{ACRONYMS}

BSR

DOE

EPA

ETTP

MAB

MSL

NAAQS

ORNL

ORR

ppm

TDEC

TVA

TWRA biological significance ranking

Department of Energy

Environmental Protection Agency

East Tennessee Technology Park

Man and the Biosphere (Program)

mean sea level

National Ambient Air Quality Standards

Oak Ridge National Laboratory

Oak Ridge Reservation

parts per million

Tennessee Department of Environment and Conservation

Tennessee Valley Authority

Tennessee Wildlife Resources Agency 



\section{ACKNOWLEDGMENTS}

This reference document pulls together basic information about physical characteristics and natural resources of the Oak Ridge Reservation (ORR) from many individuals and sources. Although it is not possible to mention everyone who has played a role in characterization of the ORR natural resources over the past 60 years, we thank and gratefully acknowledge those who have directly contributed to the preparation of this document.
Latha Baskaran
Kevin Birdwell
Terry Bonine
Sherri Cotter
Jim Evans
Neil Giffen
James Hall
LeJean Hardin
Priscilla Henson
Mark Peterson
Larry Pounds
Harry Quarles
Michael Ryon
Marti Salk
Don Sharp
Brenda Smith
Chuck Spoons
Katatra Vasquez
David Watson 



\section{OAK RIDGE RESERVATION PHYSICAL CHARACTERISTICS AND NATURAL RESOURCES}

The topography, geology, hydrology, vegetation, and wildlife of the Oak Ridge Reservation (ORR) provide a complex and intricate array of resources that directly impact land stewardship and use decisions (Fig. 1). The purpose of this document is to consolidate general information regarding the natural resources and physical characteristics of the ORR.

The ORR, encompassing 33,114 acres $(13,401 \mathrm{ha})$ of federally owned land and three Department of Energy (DOE) installations, is located in Roane and Anderson Counties in east Tennessee, mostly within the corporate limits of the city of Oak Ridge and southwest of the population center of Oak Ridge.

The ORR is bordered on the north and east by the population center of the city of Oak Ridge and on the south and west by the Clinch River/Melton Hill Lake impoundment.

All areas of the ORR are relatively pristine when compared with the surrounding region, especially in the Valley and Ridge Physiographic Province (Fig. 2). From the air, the ORR is clearly a large and nearly continuous island of forest within a landscape that is fragmented by urban development and agriculture. Satellite imagery from 2006 was used to develop a land-use/land-cover cover map of the ORR and surrounding lands (Fig. 3).

Following the acquisition of the land comprising the ORR in the early 1940s, much of the Reservation served as a buffer for the three primary facilities: the X-10 nuclear research facility (now known as the Oak Ridge National Laboratory [ORNL]), the first uranium enrichment facility or Y-12 (now known as the Y-12 National Security Complex [Y-12 Complex]), and a gaseous diffusion enrichment facility (now known as the East Tennessee Technology Park [ETTP]). Over the past 60 years, this relatively undisturbed area has evolved into a rich and diverse eastern deciduous forest ecosystem of streams and reservoirs, hardwood forests, and extensive upland mixed forests.

The combination of a large land area with complex physical characteristics and diverse natural resources has provided a critical foundation for supporting DOE's environmental research mission, as well as the area in which to build leading-edge facilities.

\section{CLIMATE}

The climate of the Oak Ridge region may be broadly classified as humid subtropical. The term humid indicates that the region receives a surplus of precipitation compared to the level of evapotranspiration that is normally experienced throughout the year. The subtropical nature of the local climate indicates that the region experiences warm to hot summers and cool to cold winters. Such areas typically experience significant changes in temperatures between summer and winter.

Local winters are characterized by synoptic weather systems that often produce significant precipitation events every 3 to 5 days. Although infrequent, these wet periods may be followed by arctic air outbreaks. While snow and ice are not usually associated with these systems, there is occasional snowfall each winter. Winter cloud cover tends to be enhanced by the region's terrain.

Severe thunderstorms are most frequent during spring, although the Cumberland Mountains and the Cumberland Plateau (Fig. 3) usually inhibit the intensity of severe systems that traverse the region. Summers are characterized by warm, humid conditions. Occasional frontal systems can produce organized lines of thunderstorms (and rare damaging tornados). More frequently, however, summer precipitation is due to air-mass thundershowers that result from daytime heating and rising humid air. Although ample precipitation usually occurs during the fall, October tends to be the driest month of the year. The occurrence of precipitation during the fall tends to be less cyclic than during other seasons, although it is occasionally enhanced by decaying tropical systems moving north from the Gulf of Mexico. During November, winter-type cyclones again begin to dominate the weather. The terrain often exhibits a significant influence on local climate. Primarily, these effects result in 


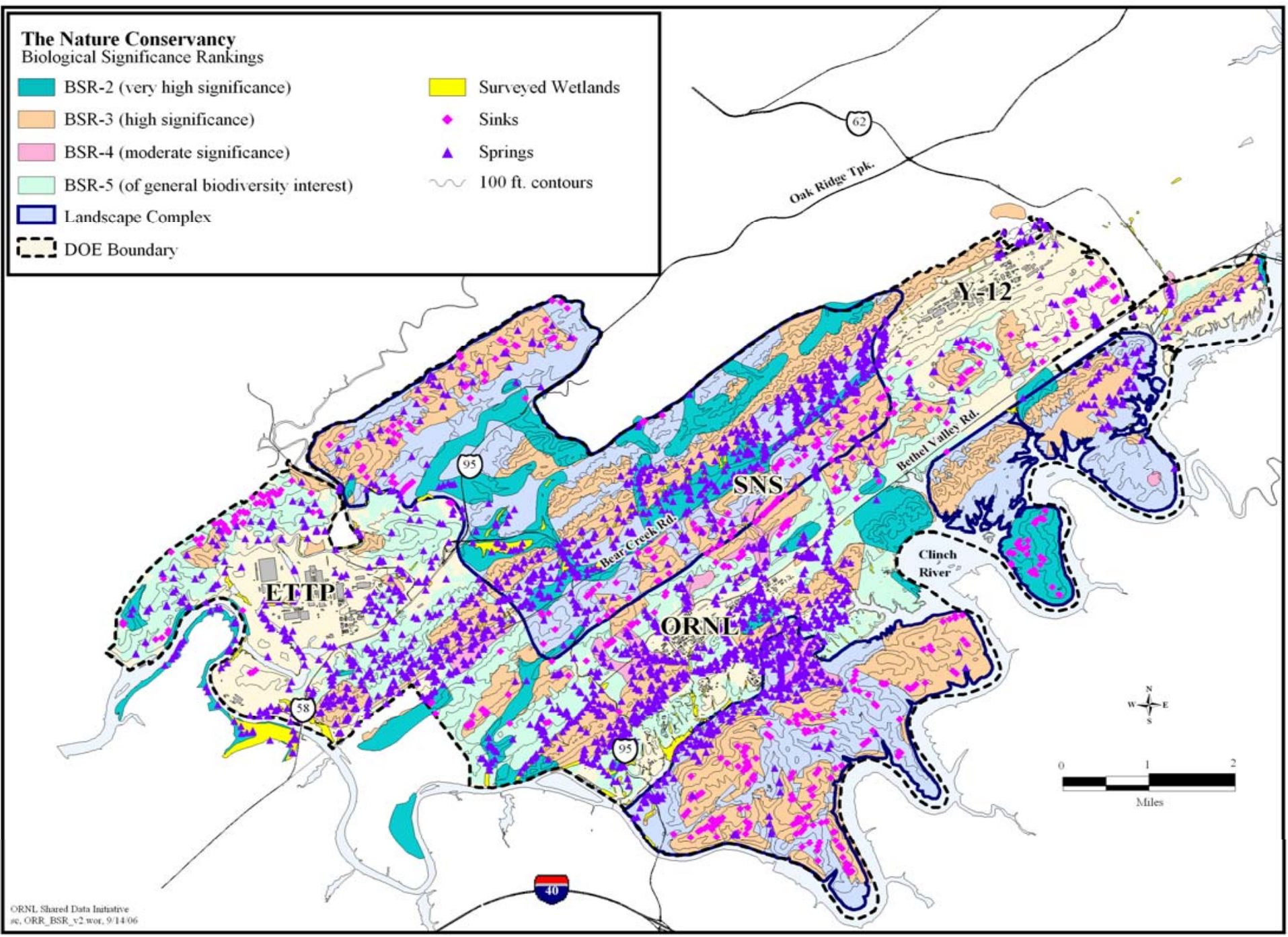

Fig. 1. ORR biologically significant areas, sinks, and springs. 


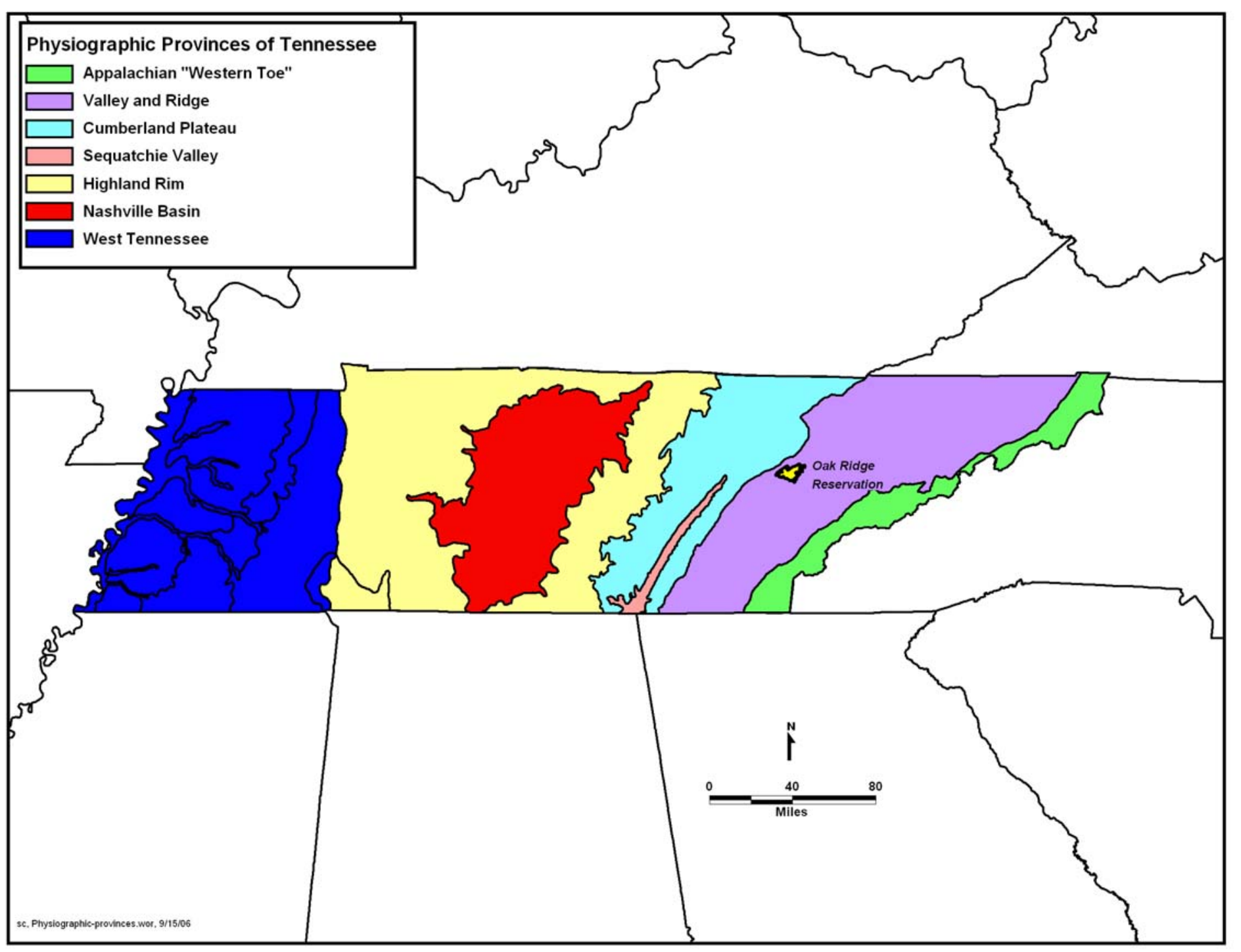

Fig. 2. ORR's position within the physiographic provinces of Tennessee. 


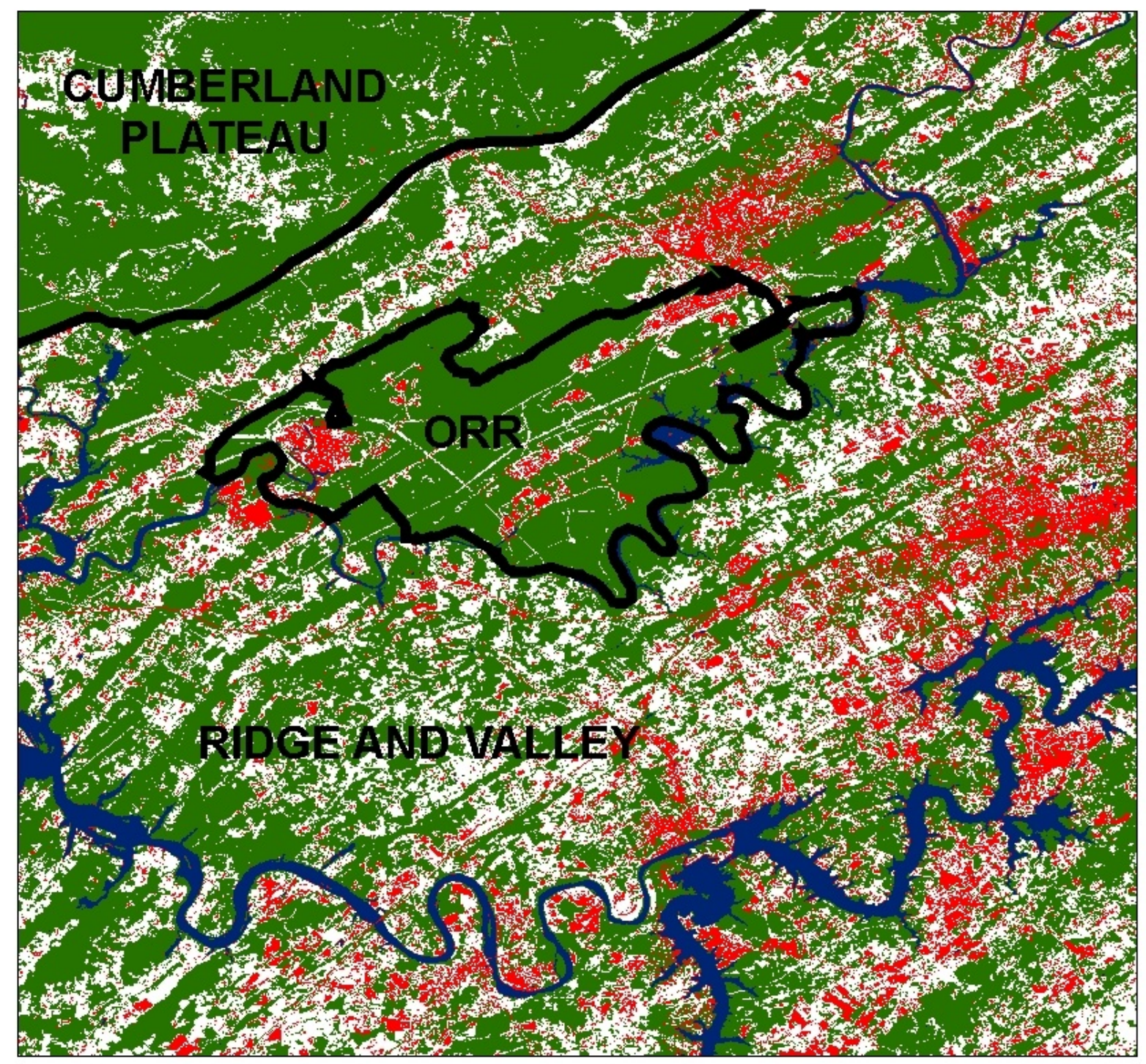

Class Names

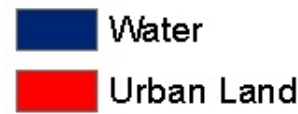

Agricultural Land

Forest Land
Scale

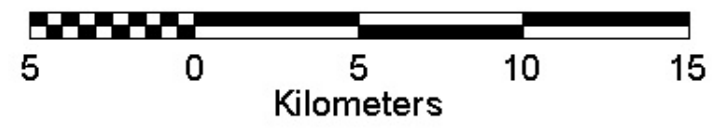

Fig. 3. Regional land-cover map prepared from a July 3, 2006, Landsat Thematic Mapper image. 
seasonal changes to cloud cover, precipitation, air mass, and wind-flow regimes.

\subsection{TEMPERATURE}

The mean 30-year annual temperature (1976-2005) for the Oak Ridge area was $58^{\circ} \mathrm{F}\left(14.4^{\circ} \mathrm{C}\right)$. The coldest month is typically January, with temperatures averaging about $36^{\circ} \mathrm{F}\left(2.3^{\circ} \mathrm{C}\right)$. However, in 1985 the minimum temperature dipped to $-24^{\circ} \mathrm{F}\left(-31^{\circ} \mathrm{C}\right)$. July tends to be the warmest month of the year, with temperatures averaging $78^{\circ} \mathrm{F}\left(25.3^{\circ} \mathrm{C}\right)$ and on rare occasions peaking as high as $99^{\circ} \mathrm{F}$ $\left(37^{\circ} \mathrm{C}\right)$.

Although average daily temperatures across the ORR are not significantly affected by the local terrain, noticeable differences do occur with respect to maximum and minimum temperatures. Such differences can result in significant temperature variations with changes in elevation as small as 33 to $67 \mathrm{ft}(10$ to $20 \mathrm{~m})$. This type of phenomenon occurs most frequently during nighttime hours (especially near sunrise) but can also occur during the approach of large-scale low-pressure areas as warm air advection interacts with the local ridge-and-valley terrain.

\subsection{WINDS}

The complex terrain significantly affects wind patterns in the Oak Ridge area. These factors primarily result from the presence of the Cumberland Plateau, the Cumberland Mountains, the Great Smoky Mountains, the orientation axis of the Great Valley (which includes most of the Valley and Ridge Physiographic Province), and the local ridge-and-valley terrain structure. Although surface winds tend to follow the axes of the valleys, winds above the ridge-and-valley terrain (altitudes of $328 \mathrm{ft}[100 \mathrm{~m}]$ or more) often blow from significantly different directions than the surface winds as a result of several wind-forcing mechanisms created by regional terrain. The presence of the ridge-andvalley terrain reduces average wind speeds at local valley-bottoms sites, resulting in frequent periods of near calm conditions (particularly during clear, early-morning hours).

Five major terrain-related wind regimes regularly affect the Great Valley of eastern Tennessee: (1) pressure-driven channeling, (2) downward-momentum transport or vertically coupled flow, (3) forced channeling, (4) along-valley thermal circulations, and (5) mountain-valley circulations. Pressure-driven channeling and vertically coupled flow (unstably stratified conditions) affect wind flow on scales comparable to that of the Great Valley (i.e., hundreds of miles). Forced channeling occurs on similar scales but is also quite important at smaller spatial scales, such as that of the local ridge-and-valley terrain (Birdwell 1996). Along-valley and mountain-valley circulations are thermally-driven and occur within a large range of spatial scales. Thermal flows are more prevalent under conditions of clear skies and low humidity. Pressure-driven channeling, in its simplest form, is the redirection of synoptically induced wind flow through a valley channel. The direction of wind flow through the valley is determined by the pressure gradient superimposed on the valley's axis (Whiteman 2000). The process is affected by Coriolis forces, a leftward deflection of winds (in the Northern Hemisphere). Eckman (1998) suggested that pressure-driven channeling plays a significant role in the Great Valley. Winds driven purely by such a process shift from up-valley to down-valley flow or conversely as weather-induced flow shifts across the axis of the Great Valley. Because the processes involved in pressure-driven flow primarily affect the horizontal motion of air, the presence of a temperature inversion significantly enhances flow. Weak vertical air motion and momentum associated with such inversions allow different layers of air to slide over each other (Monti et al. 2002). Forced channeling is the direct deflection of wind by terrain. This form of channeling necessitates some degree of vertical-motion transfer, implying that the mechanism is less pronounced during temperature-inversion conditions. Although forced channeling can result from interactions between large valleys and mountain ranges (such as the Great Valley and the surrounding mountains), the mechanism is especially important in small, narrow valleys such as those on the ORR (Kossman and Sturman 2002). Large-scale forced channeling regularly occurs within the Great Valley when 
northwest to north winds (i.e., perpendicular to the axis of the central Great Valley) coincide with vertically coupled flow. The phenomenon sometimes results in a split flow pattern (i.e., winds to the southwest of Knoxville moving down-valley and those to the east of Knoxville moving up-valley). The causes of such a flow pattern could include the shape characteristics of the Great Valley (Kossman and Sturman 2002) but also might be related to the specific location of the Cumberland and Great Smoky Mountains relative to upper-level wind flow (Eckman 1998). The convex shape of the Great Valley with respect to a northwest wind flow can lead to a divergent wind-flow pattern in the Knoxville area, resulting in downward air motion. Additionally, horizontal flow is reduced by the windward mountain range (the Cumberland Mountains), which increases buoyancy and Coriolis effects (Froude and Rossby ratios in the meteorological field). Consequently, the leeward mountain range (the Great Smoky Mountains) becomes more effective at blocking or redirecting the winds.

Vertically coupled winds occur when the atmosphere is unstable, a state characterized by cooler temperatures aloft. When a strong horizontal wind component is also present (as in conditions behind a winter cold front), winds ignore the terrain, flowing over it in roughly in the same direction as the winds aloft. This phenomenon is a consequence of the horizontal transport and momentum aloft being transferred to the surface. However, Coriolis effects can turn the winds by up to $25^{\circ}$ to the left (Birdwell 1996).

Thermally driven winds are common in areas of significantly complex terrain. These winds occur as a result of pressure and temperature differences caused by varied surface-air energy exchange at similar altitudes along a valley's axis, sidewalls, and/or slopes. Thermal flows operate most effectively when synoptic winds are light and thermal differences are exacerbated by clear skies and low humidity (Whiteman 2000). The ridge-and-valley terrain can be responsible for enhancing or inhibiting such airflow, depending on the ambient weather conditions. Eckman (1998) suggested that the presence of daytime up-valley winds and nighttime down-valley (drainage) flows between the ridge-and-valley terrain of the Oak Ridge area tended to reverse at about 9:00 to 11:00 a.m. and at about 5:00 to 7:00 p.m. local time. The terrain-following nature of drainage winds suggests that they would be more directly impacted by the presence of the ridge-and-valley terrain than daytime flows, which tend to be accompanied by significant vertical motions.

\subsection{PRECIPITATION}

The 30-year annual average precipitation for 1976-2005 was 54 in. (137 cm), including about 11 in. $(27.4 \mathrm{~cm})$ of snowfall (NOAA 2006).

\subsection{EVAPOTRANSPIRATION}

Evapotranspiration is defined as the total amount of water that is transferred from the earth's surface to the atmosphere from surface water and ice by evapotranspiration and from the transpiration of plants. (Transpiration refers to the process through which water vapor is released by plants to the atmosphere.) Regionally, annual evapotranspiration has been estimated to range from 32 to 35 in. (81 to $89 \mathrm{~cm}$ ), or 60 to $65 \%$ of rainfall (Farnsworth, Thompson, and Peck 1982). More specifically, evapotranspiration in the Oak Ridge area has been estimated at 29 to $30 \mathrm{in}$. (74 to $76 \mathrm{~cm}$ ), or 55 to $56 \%$ of annual precipitation (TVA 1972; Moore 1988; and Hatcher et al. 1989).

Evapotranspiration is greatest during the growing season, which in the vicinity of the ORR encompasses about 220 days, from late March through mid-October. During the growing season, evapotranspiration can exceed the rate of precipitation, resulting in soil-moisture deficits.

\subsection{MIXING HEIGHTS}

The mixing height (i.e., the atmospheric layer nearest the earth's surface where active diffusion and mixing occur) varies significantly with respect to time of day, synoptic weather, season, and 
proximity to terrain. The depth of the surface mixing layer is usually correlated to atmospheric stability, which is the tendency of the atmosphere to mix vertically. The local ridge-and-valley terrain primarily affects stability through the reduction of surface winds, which tends to allow for the development of very stable surface layers (i.e., strong temperature inversions) at night, particularly under clear skies and light background winds.

\subsection{STABILITY}

Stability describes the tendency of the atmosphere to mix or overturn. Consequently, dispersion parameters are influenced by the stability characteristics of the atmosphere. Stability classes range from "A" (very unstable) to "G" (very stable). The "D" stability class represents a neutral state. The local ridge-and-valley terrain plays a role in the development of stable surface air under certain conditions and influences the dynamics of airflow.

The suppression of vertical motions during stable conditions increases the frequency with which air motion is impacted by the local terrain. Conversely, stable conditions isolate wind flows within the ridge-and- valley terrain from the effects of more distant terrain features and from winds aloft. These effects are particularly true with respect to mountain waves. Deep stable layers of air tend to reduce the vertical space available for oscillating vertical air motions caused by local mountain ranges (Smith et al. 2002). This effect on mountain-wave formation could be important with regard the impact that the nearby Cumberland Mountains might have on local airflow.

A second factor that could decouple large-scale wind-flow effects from local ones (and thereby produce stable surface layers) occurs with overcast-sky conditions. Clouds overlying the Great Valley can warm as a result of direct insulation on the cloud tops. Warming can also occur within the clouds as latent energy is released because of the condensation of moisture. Surface air underlying the clouds can remain relatively cool (because it is cut off from direct exposure to the sun). Consequently, the vertical temperature gradient associated with the air mass can become more stable (Lewellen and Lewellen 2002). Long wave cooling of a fog deck has also been observed to help modify stability in the surface layer (Whiteman et al. 2001). Stable boundary layers typically form as a result of radiational cooling processes near the ground (Van de Weil et al. 2002); however, they are also influenced by the mechanical energy supplied by horizontal wind motion (which is in turn influenced by the large-scale weather-related pressure gradient). The ridge-and-valley terrain can have a significant ability to block such winds and their associated mechanical energy (Carlson and Stull 1986). Consequently, enhanced radiational cooling at the surface results because less wind energy is available to remove chilled air.

Stable boundary layers also exhibit intermittent turbulence that has been associated with a number of the above factors. The process results from give-and-take between the effects of friction and radiational cooling. As a stable surface layer intensifies through a radiation cooling process, it tends to decouple from air aloft, thereby reducing the effects of surface friction. The upper air layer responds with an acceleration in wind speed. Increased wind speed aloft results in an increase in mechanical turbulence and wind shear at the boundary with the stable surface layer. Eventually, the turbulence works into the surface layer and weakens it. As the inversion weakens, friction again increases, reducing winds aloft. The reduced wind speeds aloft allow enhanced radiation cooling at the surface, which re-intensifies the inversion and allows the process to start again. Van de Weil et al. (2002) have shown that cyclical temperature oscillations up to $39^{\circ} \mathrm{F}$ can result from these processes. Because these intermittent processes are primarily driven by large-scale horizontal wind flow and radiational cooling of the surface, the ridge-and-valley terrain significantly affects these oscillations. 


\section{REGIONAL AIR QUALITY}

The Environmental Protection Agency (EPA) Office of Air Quality Planning and Standards has set National Ambient Air Quality Standards (NAAQS) for key principal pollutants, which are called criteria pollutants. These pollutants are sulfur dioxide $\left(\mathrm{SO}_{2}\right)$, carbon monoxide $(\mathrm{CO})$, carbon dioxide $\left(\mathrm{CO}_{2}\right)$, nitrogen dioxide $\left(\mathrm{NO}_{2}\right)$, lead $(\mathrm{Pb})$, ozone $\left(\mathrm{O}_{3}\right)$, particulate matter with aerodynamic diameter less than or equal to $2.5 \mu \mathrm{m}\left(\mathrm{PM}_{2.5}\right)$, and particles with an aerodynamic diameter less than or equal to $10 \mu \mathrm{m}$ in diameter $\left(\mathrm{PM}_{10}\right)$. EPA evaluates NAAQS based on ambient (outdoor) levels of the criteria pollutants. Areas that satisfy NAAQS are classified as attainment areas, while areas that exceed NAAQS for a particular pollutant are classified as nonattainment areas for that pollutant.

The ORR is located in Anderson and Roane Counties in Air Quality Control Region 207 (East Tennessee-Southeastern Virginia). EPA has designated Anderson County as a basic nonattainment area for the 8-h $\mathrm{O}_{3}$ standard, as part of the larger Knoxville 8-h basic $\mathrm{O}_{3}$ nonattainment area that encompasses several counties, and for $\mathrm{PM}_{2.5}$. For all other criteria pollutants for which EPA has made attainment designations, existing air quality in the greater Knoxville and Oak Ridge area is in attainment as defined by NAAQS.

\section{TOPOGRAPHY AND GEOLOGY}

The ORR is located in the Valley and Ridge Physiographic Province, which is characterized by a series of parallel narrow, elongated ridges and valleys that follow a northeast-to-southwest trend (Hatcher et al. 1992). The Valley and Ridge Physiographic Province has developed on thick, folded beds of sedimentary rock deposited during the Paleozoic era. The long axes of the folded beds control the shapes and orientations of a series of long, narrow parallel ridges and intervening valleys. These axes of the ridge-and-valley terrain within the ORR lie approximately along an east-northeast-westsouthwest axis $\left(60-240^{\circ}\right)$. The differing degrees of resistance to erosion of the shales, sandstones, and carbonate rocks comprised in the lithology determine local relief.

The topography and slope of the ORR are shown in Fig. 4, bedrock geology is shown in Fig. 5, and watershed information is shown in Fig. 6. The elevation within the ORR ranges from a low of $750 \mathrm{ft}(229 \mathrm{~m})$ mean sea level (MSL) along the Clinch River to a high of $1260 \mathrm{ft}(384 \mathrm{~m})$ MSL along Pine Ridge. The topographic relief between valley floors and ridge crests is generally about 300 to $350 \mathrm{ft}(91.5$ to $107 \mathrm{~m})$. Weathering and erosion processes, coupled with the generally southerndipping attitude of bedrock underlying the area, result in rather steep (commonly steeper than $45^{\circ}$ ) northwest-facing slopes, while southeast-facing slopes are commonly gentler (Fig. 4). Terrain at the ORR is hilly, with slopes that average about $7.5 \%$ and that range from less than $3 \%$ to more than $50 \%$.

The bedrock on the ORR ranges in age from 350 to 550 million years old (Fig. 5). The valleys are typically underlain by bedrock formations predominated by siltstones and limestones, including the Conasauga Group and the Chickamauga Group. The Conasauga Group consists primarily of shale interbedded with shaley to silty limestone. The Chickamauga Group consists primarily of limestone, with layers of siltstone. Ridges are underlain by two different types of erosion-resistant bedrock: (1) formations predominated by sandstones, siliceous shales, and siltstones (Rome Formation and Post-Chickamauga rocks) and (2) siliceous dolostones of the Knox Group (Hatcher et al. 1992) The Rome Formation and Post-Chickamauga rocks are typified by steep slopes and shallow depths to bedrock. The Knox Group consists of silica-rich carbonate rocks that can deeply weather to form a thick mantle of silty clay soils rich in chert.

The Rome Formation and the Conasauga, Chickamauga, and Post-Chickamauga Groups generally have limited capacity to transmit or store groundwater (aquitards). The Knox Group and the adjacent Maynardville Limestone in the Conasauga Group are the principal groundwater-bearing rock units (aquifers) on the ORR. A combination of fractures and solution conduits in this aquifer control 


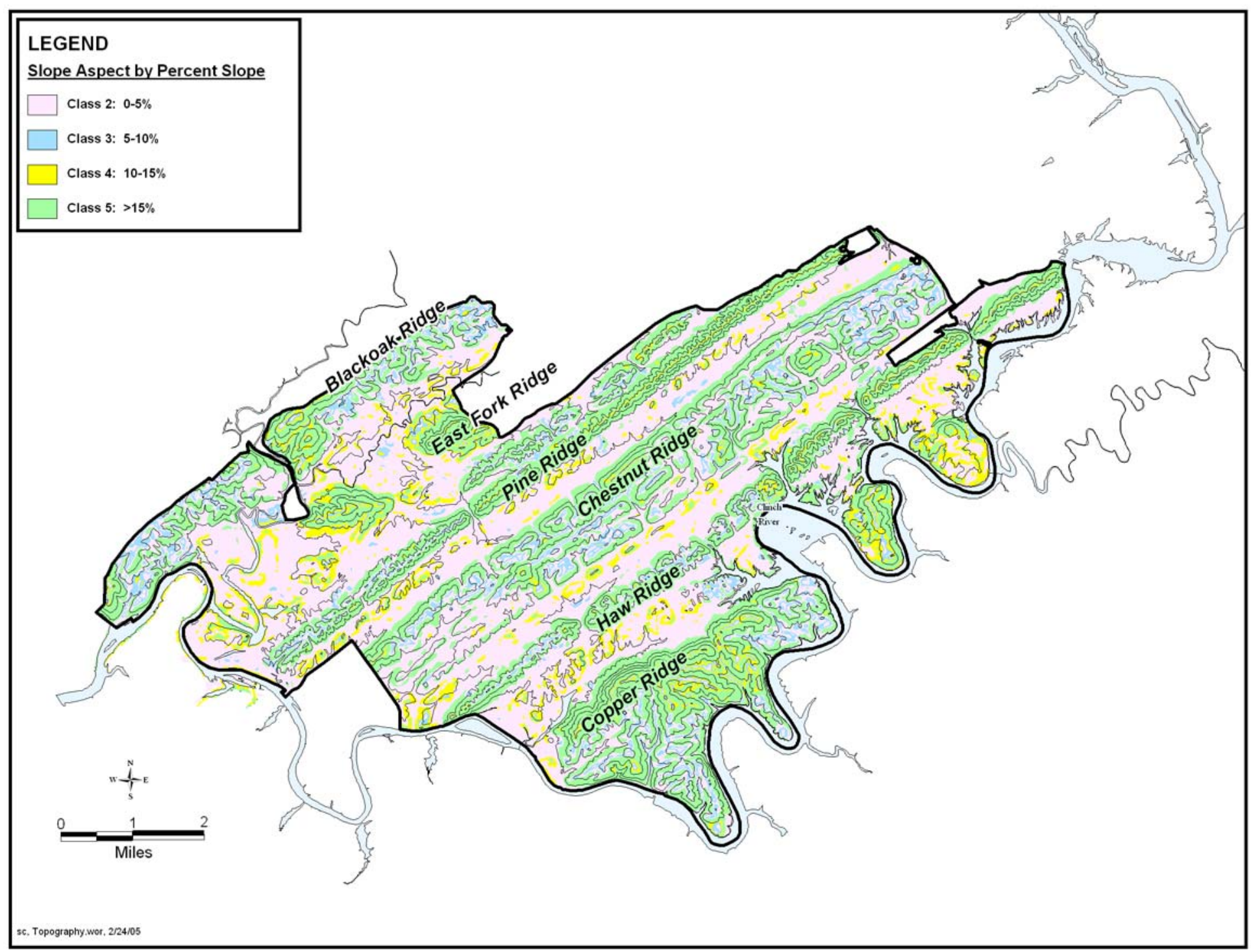

Fig. 4. ORR topography with slope. 


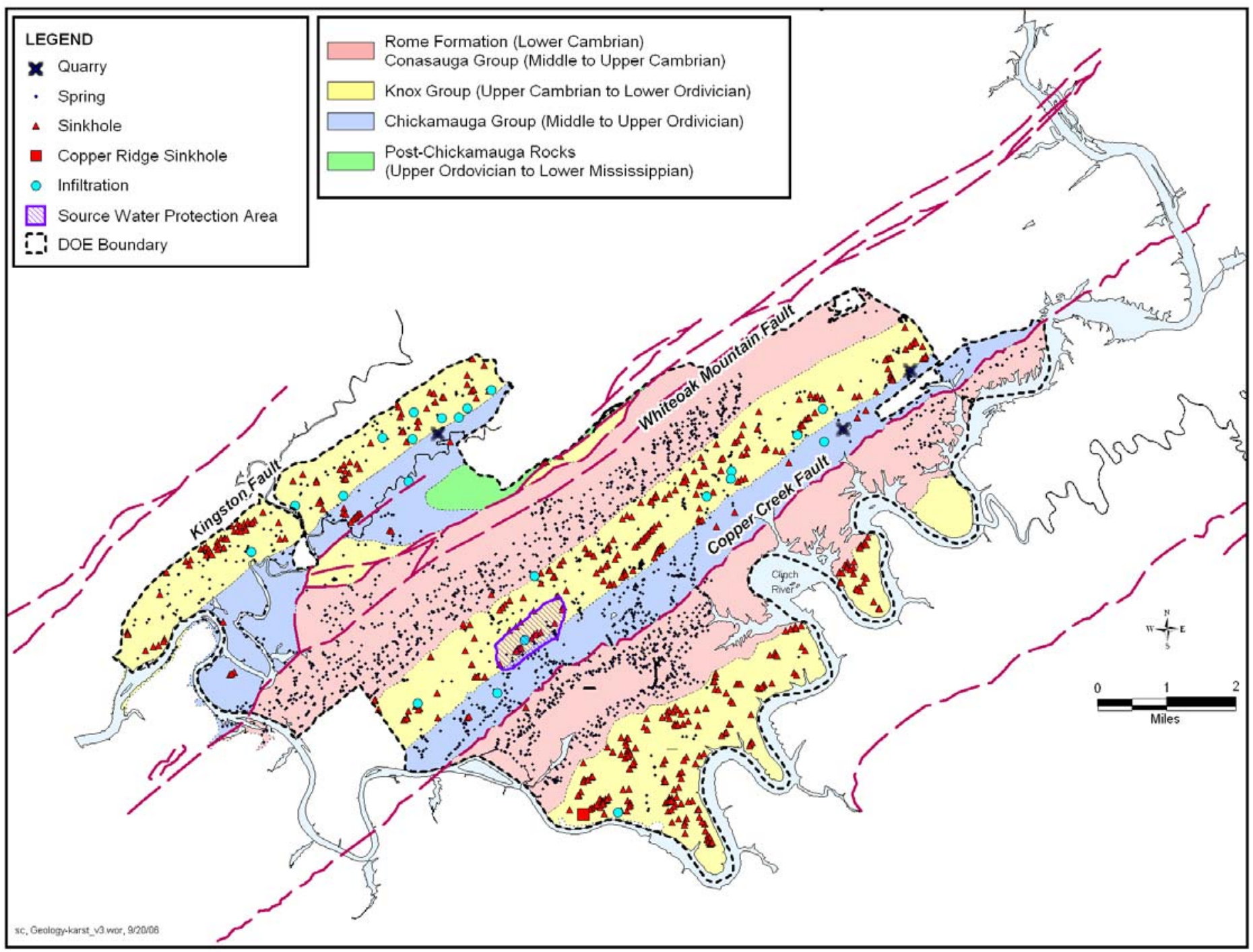

Fig. 5. ORR geology with karst features. 


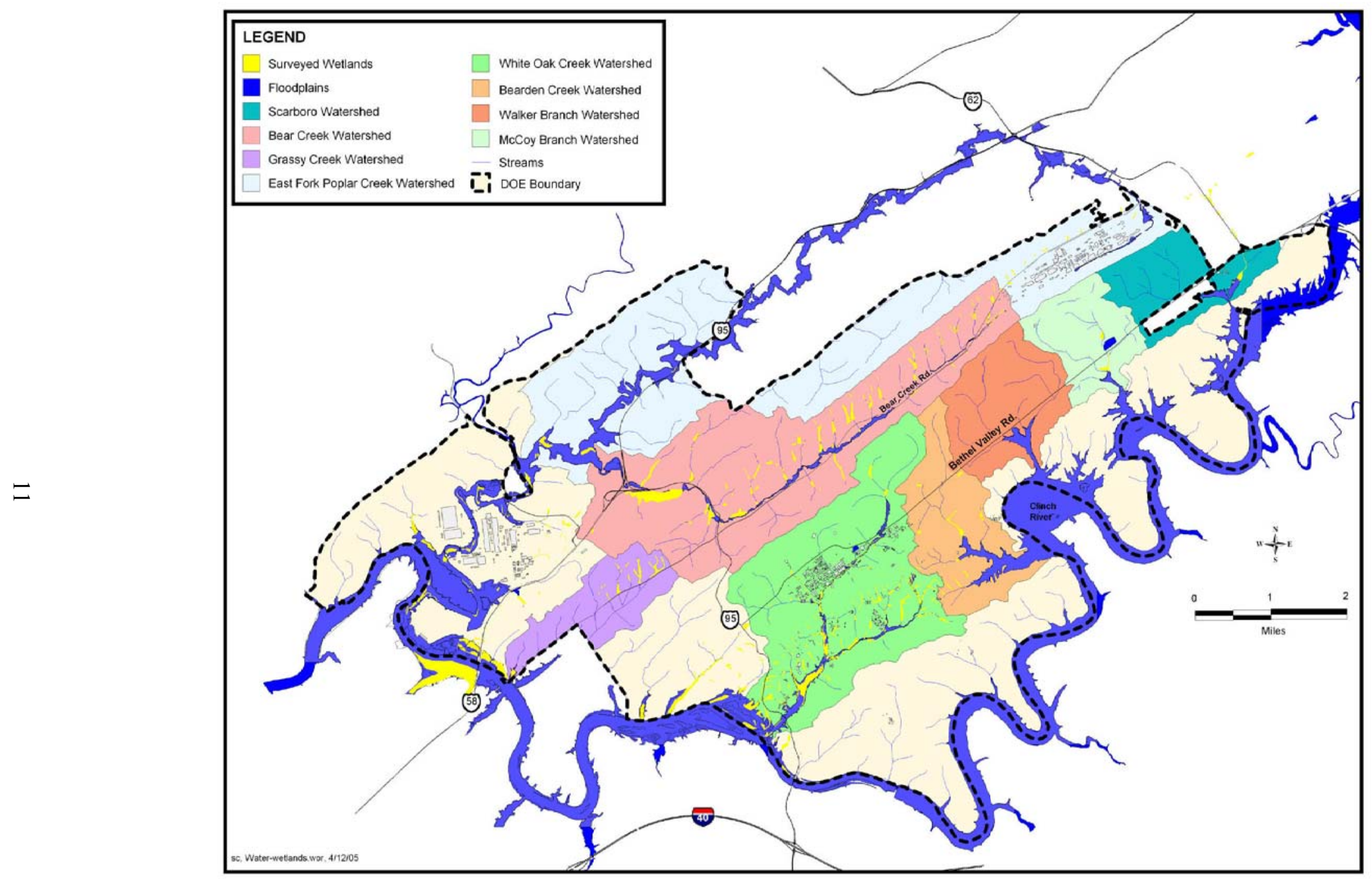

Fig. 6. Water, wetlands, floodplains, and watersheds on the ORR. 
flow over substantial areas, and large quantities of water can move long distances. Active groundwater flow can occur at substantial depths in the Knox Aquifer (300 to $400 \mathrm{ft}$ [91.5 to $122 \mathrm{~m}$ ] deep). The Knox Aquifer is the primary source of groundwater to many streams (i.e., base flow), and most large springs on the ORR receive discharge from the Knox Aquifer.

The remaining geologic units on the ORR (the Rome Formation, the Conasauga Group [below the Maynardville Limestone], and the Chickamauga Group) constitute the ORR Aquitards, which consist mainly of siltstone, shale, sandstone, and thinly bedded limestone of low to very low permeability. Nearly all groundwater flow in the ORR Aquitards occurs through fractures. The typical yield of a well in the ORR Aquitards is less than $1 \mathrm{gal} / \mathrm{min}(3.8 \mathrm{~L} / \mathrm{min})$, and the base flows of streams draining areas underlain by the ORR Aquitards are poorly sustained because of such low flow rates.

While topography and underlying geology typically control surface water and groundwater flow, widespread fracturing and faulting can also impact flow. In addition, carbonate rock units display dissolutional features and landforms, collectively referred to as karst. Karst features observed on the ORR range from minor solutional enlargement of fractures, to larger conduit flow paths, to enterable caves (Fig. 5). All three ORR facilities are situated on carbonate bedrock to some extent, so groundwater flow and contaminant transport are at least partially controlled by solution conduits.

Karst appears to be most developed in association with the Knox Group and adjacent Maynardville Limestone carbonate units. The highest density of sinkholes occurs in the Knox Group, and drilling data suggest that the largest solution cavities are associated with these formations. Large karst-related springs typically occur along the base of the ridges underlain by the Knox Group and Maynardville Limestone. Property damage in recent years to residential homes on neighboring properties as a result of settlement has highlighted the potential for collapse in areas underlain by cavernous limestone. Because karst features are best developed in the Knox Group carbonates, the potential for collapse is greatest in areas underlain by this formation.

\section{SURFACE WATER}

Waters drained from the ORR eventually reach the Tennessee River via the Clinch River, which forms the southern and western boundaries of the ORR. The ORR lies within the Valley and Ridge Physiographic Province, which is composed of a series of drainage basins or troughs containing many small streams feeding the Clinch River. Surface-water hydrology on the ORR is characterized by a network of small streams that are tributaries of the Clinch River (Fig. 6). Surface water at each of the major facilities of the ORR drains into a tributary or series of tributaries, streams, or creeks within different watersheds. Each of these watersheds drains into the Clinch River, affecting different subbasins (Fig. 6). The largest of the drainage basins is that of Poplar Creek, which receives drainage from a 136 mile $^{2}\left(352-\mathrm{km}^{2}\right)$ area, including the northwestern sector of the ORR. It flows from northeast to southwest, approximately through the center of ETTP, and discharges directly into the Clinch River.

East Fork Poplar Creek, which discharges into Poplar Creek east of ETTP, originates within the Y-12 Complex near the former S-3 Ponds and flows northeast along the south side of the Y-12 Complex. Various Y-12 Complex wastewater discharges to the upper reaches of East Fork Poplar Creek from the late 1940s to the early 1980s left a legacy of contamination (e.g., mercury, polychlorinated biphenyls, uranium) that has been the subject of water-quality improvement initiatives over the past 12 to 15 years. Bear Creek also originates within the Y-12 Complex, with its headwaters near the former S-3 Ponds where the creek flows southwest. Bear Creek is mostly affected by stormwater runoff, groundwater infiltration, and tributaries that drain former waste disposal sites in the Bear Creek Valley Burial Grounds Waste Management Area and the current Environmental Management Waste Management Facility.

Both the Bethel Valley and Melton Valley portions of ORNL are in the White Oak Creek drainage basin, which has an area of 6.4 mile $^{2}\left(16.5 \mathrm{~km}^{2}\right)$. White Oak Creek headwaters originate on 
Chestnut Ridge, north of ORNL, near the Spallation Neutron Source site. At the ORNL site, the creek flows east along the southern boundary of the developed area and then southwesterly through a gap in Haw Ridge to the western portion of Melton Valley, where it forms a confluence with Melton Branch. The waters of White Oak Creek enter White Oak Lake, which is an impoundment formed by White Oak Dam. Water flowing over White Oak Dam enters the Clinch River after passing through the White Oak Creek embayment area.

Water levels in the Clinch River are regulated by the Tennessee Valley Authority (TVA), and fluctuations in the river can have an effect on streams draining the ORR. Most of the ORR is located above the probable maximum flood elevation along the Clinch River.

\section{SUBSURFACE HYDROLOGY}

\subsection{GROUNDWATER HYDROLOGY}

A portion of the rainwater that falls on the land surface accumulates as groundwater by infiltrating into the subsurface. The accumulation of groundwater in pore spaces of sediments and bedrock creates sources of usable water; the water flows in response to external forces. Groundwater eventually reappears at the surface in springs, swamps, stream and river beds, and pumped wells. Thus, groundwater is a reservoir for which the primary input is recharge from infiltrating rainwater, and the output is discharged to springs, swamps, rivers, streams, and wells.

Groundwater on the ORR occurs both in the unsaturated zone as transient, shallow subsurface storm flow and within the deeper saturated zone. An unsaturated zone of variable thickness separates the storm-flow zone and water table. Adjacent to surface water features or in valley floors, the water table is found at shallow depths, and the unsaturated zone is thin. Along the ridge tops or near other high topographic areas, the unsaturated zone is thick, and the water table often lies at considerable depth (49 to $164 \mathrm{ft}$ [15 to $50 \mathrm{~m}$ ] deep). In low-lying areas in which the water table occurs near the surface, the storm-flow and saturated zones are indistinguishable. Figure 7 is a generalized schematic showing the relationship between the streamflow zone, water table, and unsaturated (vadose) and saturated (phreatic) zones.

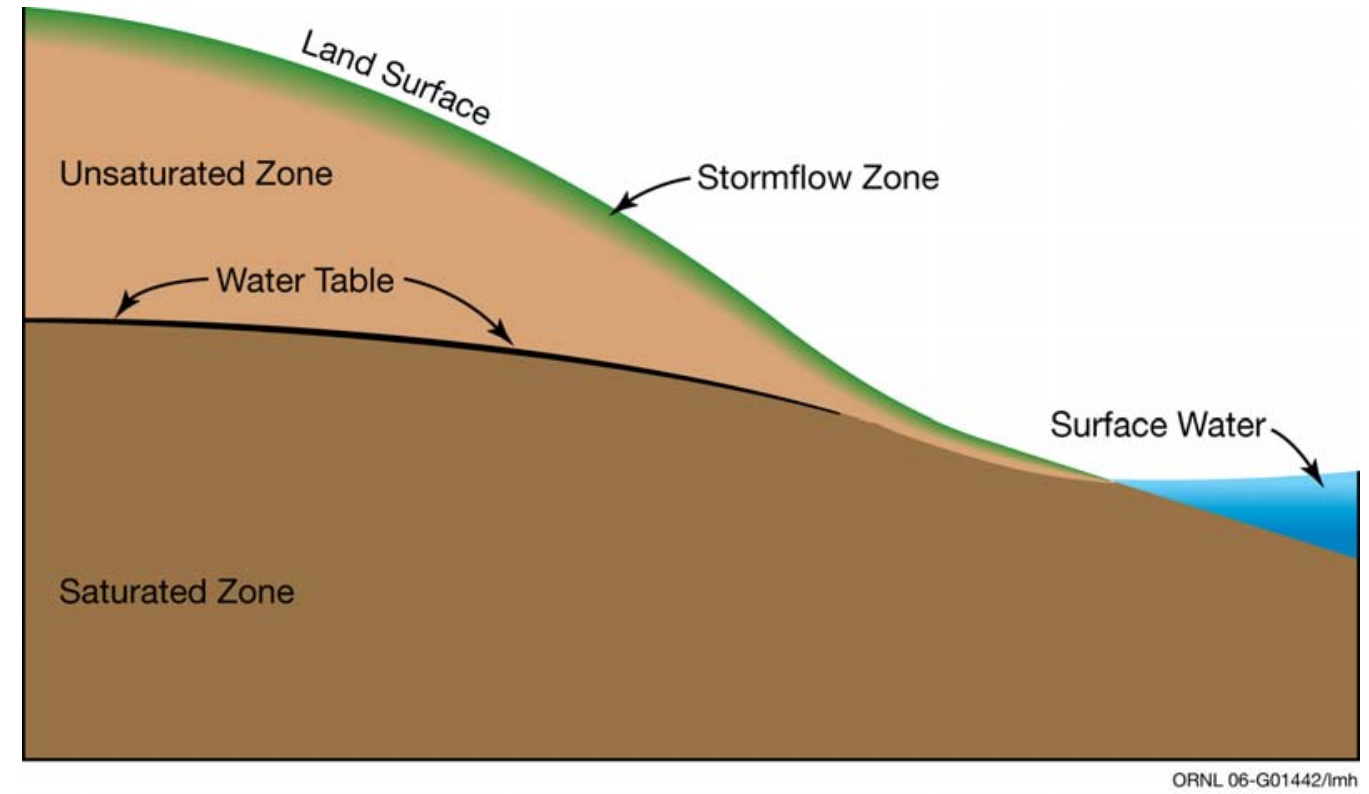

Fig. 7. Relationship between stormflow zone, water table, and unsaturated and saturated zones. 
Two broad hydrologic units have been identified on the ORR: (1) the Knox Aquifer, which includes the Maynardville Limestone and is highly permeable, and (2) the ORR Aquitards, which consist of less permeable geologic units. The geologic regime referred to as the ORR Aquitards comprises bedrock and residuum of the Cambrian-age Rome Formation and Conasauga Group (excluding the Maynardville Limestone) and the Chickamauga Group. Bedrock included in these formations is predominantly clastic sediment (shales, siltstones, well-cemented sandstones, and clayey to silty limestones). The ORR Aquitards include local zones in which groundwater occurs in quantities sufficient to provide a potential resource of limited use. These zones typically occur within karstic carbonate members of the clastic bedrock formations. Although marginal localized groundwater resources occur within the ORR Aquitards, these formations are far less important to regional water resources - including being a source of potable water for private and public water supply and a source of baseflow to regional surface water bodies - than is the Knox Aquifer.

Portions of the ORR underlain by carbonate bedrock commonly exhibit karst geomorphic features. About $60 \%$ of the ORR is underlain by carbonate-dominated bedrock. Karst geomorphic features form in carbonate-rich bedrock and are evident as sinkholes, solution caverns, and sinking creeks. In addition to creation of subsurface voids in bedrock, the weathering process leaves behind the insoluble mineral components of the rock that combine with organic residues of decaying plant materials to form a soil mantle over most of the ORR. The soil mantle forms a physical and geochemical filter that reduces the direct infiltration of rainfall and contaminants into the groundwater system. Geochemical retardation of contaminants in the soil mantle reduces the mobility of many types of contaminants. Groundwater flow in most of the carbonates is quite different from flow in porous media, in which advective flow conditions largely govern flow and solute transport. Groundwater flow in karst terranes manifests itself in multiple scales of porosity, such as diffusion in intergranular pores of weathered or inherently porous bedrock, flow by seepage in rock fractures with water and rock matrix interaction on fracture surfaces, or flow in conduits in which rapid velocities limit the interaction between the water and bedrock. Groundwater discharge from springs and seeps is abundant on the ORR and accounts for the normal baseflow of natural stream systems in the area. Most recharge to the groundwater system occurs through dispersed percolation of rainwater through the soil mantle and through capture in surface dolines (i.e., sinkholes) during the winter and early spring months, when evapotranspiration losses of soil moisture are negligible. Groundwater storage in thick soil profiles and in the weathered bedrock zone of the Knox Group outcrop areas such as Blackoak, Chestnut, and Copper Ridges provides most of the dry-season baseflow and feeds the area's largest springs. Most groundwater flow in the carbonate bedrock groundwater basins on the ORR originates as intergranular or fracture seepage through the soil mantle, and flow progresses through coalescing networks of conduits that culminate at spring discharges. Baseflow springs often occur near major geologic outcrop boundaries, where semiconfining bedrock lithologies tend to limit the orientation of conduit development and promote upward flow of groundwater to discharge at the land surface. In portions of the ORR underlain by shale-rich bedrock, such as the Conasauga Group bedrock of Bear Creek Valley and Melton Valley, groundwater seepage is typically through fractures in weathered bedrock with discharge to nearby streams. Discrete baseflow springs are not common in the shale-dominated outcrop areas; however, small seeps are abundant.

\subsection{UNSATURATED ZONE HYDROLOGY}

Because ORR landforms consist almost entirely of sloping land surfaces, the concepts of hillslope hydrology may be used to describe the active hydrologic process. Based on soil percolation capacity and soil structure, as well as direct measurement of water transmission in soil test areas, it is estimated that in undisturbed, naturally vegetated areas on the ORR, about $90 \%$ of the infiltrating precipitation does not reach the water table but travels through the 3- to $6.5-\mathrm{ft}$ (1- to 2-m) storm-flow zone, which approximately corresponds to the root zone. This condition exists because of the permeability contrast between the shallow storm-flow zone and the underlying unsaturated zone. 
Recharge of the groundwater system is strongly seasonal at the ORR, and percolation processes in the shallow soil are moderated by the amount of soil moisture present. During the active growing season (April through October) evapotranspiration by plants removes moisture from the soil within the root zone. When soil moisture levels are low, any percolating rainwater is absorbed in the root zone to replenish the soil moisture deficit. During that phase little or no water reaches the water table.

When rainfall amounts exceed any existing soil moisture deficits and saturation of the shallow soils begins to occur, seepage of water begins. When saturation of the shallow soils occurs on sloping land, the downslope gradient allows lateral drainage of water through macropores (e.g., holes left by decay of dead plant roots, animal burrows) as well as vertical seepage to the water table through pervious zones. During the nongrowing season (November through March), there is little evapotranspiration to remove water from the root zone, and saturation of the shallow soils occurs more rapidly than during the summer months. Typical evapotranspiration losses from the root zone range from a low of about $0.01 \mathrm{in} . / \mathrm{d}(0.025 \mathrm{~cm} / \mathrm{d})$ rainfall equivalent during January and February to a high of about $0.16 \mathrm{in} . / \mathrm{d}(0.41 \mathrm{~cm} / \mathrm{d})$ rainfall equivalent during July. Thus, development of a 1-in. $(2.5-\mathrm{cm})$ water deficit would require only 1 week without rainfall during July but more than 2 months without rainfall during the winter.

The amount of water that actually recharges the groundwater zone is highly variable across the ORR, depending on the shallow soil characteristics, permeability and degree of fracturing of regolith (rocky, weathered in place) beneath the surface soils, presence of dolines that capture storm flow and focus recharge in small areas, and presence of paved or covered areas in which little or no rainfall infiltration occurs. Higher recharge is expected in areas of karst hydrogeology such as the Knox Aquifer because of internal drainage through dolines than in areas underlain by the clastic bedrock formations.

\subsection{SATURATED ZONE HYDROLOGY}

The saturated zone on the ORR can be conceptually divided into four flow zones in a vertical cross section: (1) an uppermost water-table interval, (2) an intermediate interval, (3) a deep interval, and (4) an aquiclude (i.e., a zone of extremely low permeability). The presence and thickness of any zone can vary across the ORR. Available evidence indicates that most water in the saturated zone (i.e., the water table to the intermediate interface) in the ORR Aquitards is transmitted through a 3- to $20-\mathrm{ft}$ (1- to 6-m) layer of closely spaced, well-connected fractures. The water table is a surface that defines the upper limit of saturation.

As in the storm-flow zone, the bulk of groundwater in the saturated zone resides within the pore spaces of the rock matrix. The rock matrix typically forms blocks that are bounded by fractures. Contaminants migrating from sources by way of the fractures typically occur in higher concentrations than in the matrix; thus, the contaminants tend to move (diffuse) into the matrix. This process, termed diffusive exchange or matrix diffusion, between water in matrix pores and water in adjacent fractures reduces the overall contaminant migration rates relative to groundwater-flow velocities. For example, the leading edge of a geochemically nonreactive contaminant mass such as tritium might migrate along fractures at a typical rate of $3 \mathrm{ft} / \mathrm{d}(1 \mathrm{~m} / \mathrm{d})$; however, the center of mass of a contaminant plume typically migrates at a rate less than $2 \mathrm{ft} / \mathrm{d}(0.66 \mathrm{~m} / \mathrm{d})$.

In the ORR Aquitards, chemical characteristics of groundwater change from a mixed-cation$\mathrm{HCO}_{3}$ water type at shallow depth to an $\mathrm{Na}-\mathrm{HCO}_{3}$ water type at deeper levels $(100 \mathrm{ft}[30.5 \mathrm{~m}])$. This transition, not marked by a distinct change in rock properties, serves as a useful marker and can be used to distinguish the more active water table and intermediate groundwater intervals from the sluggish flow of the deep interval. There is no evidence of similar change with depth in the chemical characteristics of water in the Knox Aquifer; virtually all wells are within the monitoring regime of $\mathrm{Ca}-\mathrm{Mg}-\mathrm{HCO}_{3}$-type water. Although the mechanism responsible for this change in water types is poorly understood, it most likely is related to the amount of time the water is in contact with a specific type of rock. 
Most groundwater flow in the saturated zone occurs within the water-table interval. Most flow is through weathered, permeable fractures and matrix rock and within solution conduits in the Knox Aquifer. The range of seasonal fluctuations of water-table depth and rates of groundwater flow vary significantly across the reservation. In areas underlain by the Knox Aquifer, seasonal fluctuations in water levels average $17 \mathrm{ft}(5.3 \mathrm{~m})$, and mean discharge from the active groundwater zone is typically $85 \mathrm{gal} / \mathrm{min}(322 \mathrm{~L} / \mathrm{min})$ per $1 \mathrm{mile}^{2}\left(2.6 \mathrm{~km}^{2}\right)$. In the ORR Aquitards of Bear Creek Valley, Melton Valley, East Fork Valley, and Bethel Valley, seasonal fluctuations in water levels average $5 \mathrm{ft}$ $(1.5 \mathrm{~m})$, and typical mean discharge is $26 \mathrm{gal} / \mathrm{min}(98 \mathrm{~L} / \mathrm{min})$ per $1 \mathrm{mile}^{2}\left(2.6 \mathrm{~km}^{2}\right)$.

In the intermediate interval, groundwater flow paths are products of fracture density and orientation. Groundwater movement primarily occurs in fractures that are poorly connected. In the Knox Aquifer, a few cavity systems and fractures control groundwater movement in this zone, but in the ORR Aquitards, the bulk of flow is through fractures, along which permeability can be increased by weathering.

The deep interval of the saturated zone is delineated by a change to an $\mathrm{Na}-\mathrm{Cl}$ water type. Hydrologically active fractures in the deep interval are significantly fewer and shorter than in the other intervals, and the spacing is greater. Wells in the deep interval of the ORR Aquitards typically yield less than $0.3 \mathrm{gal} / \mathrm{min}(1.1 \mathrm{~L} / \mathrm{min}$.) and thus are barely adequate for water supply.

In the ORR Aquitards, saline water characterized by total dissolved solids ranging up to 275,000 parts per million $(275,000 \mathrm{mg} / \mathrm{L})$ and chlorides generally in excess of 50,000 ppm $(50,000 \mathrm{mg} / \mathrm{L})($ ranging up to $163,000 \mathrm{ppm}[163,000 \mathrm{mg} / \mathrm{L}])$ lies beneath the deep interval of the groundwater zone, delineating an aquiclude. Chemically, this water resembles brines typical of major sedimentary basins, which originated from evaporating water bodies. The brines are thought to have been pushed westward and trapped by overthrusting rock during the formation of the Appalachian Mountains (about 250 million years ago). The chemistry suggests extremely long residence times (i.e., very low flow rates); however, some mixing with shallow groundwater has been observed (Nativ, Halleran, and Hunley 1997).

The aquiclude has been encountered at depths of 400 and $800 \mathrm{ft}$ (122 and $244 \mathrm{~m}$ ) in Melton and Bethel Valleys, respectively, (near ORNL), and it is believed to approach $1000 \mathrm{ft}$ (305 m) in portions of Bear Creek Valley (near the Y-12 Complex) underlain by aquitard formations. The depth to the aquiclude in areas of the Knox Aquifer is not known but is believed to be greater than $1200 \mathrm{ft}$ $(366 \mathrm{~m})$. The depth to the aquiclude has not been established in the vicinity of ETTP.

\subsection{GROUNDWATER FLOW}

Many factors influence groundwater flow on the ORR. Topography, surface cover, geologic structure, karst features, and rock type exhibit especially strong influences on the hydrogeology. Variations in these features result in variations in the total amount of groundwater moving through the system (flux). As an example, the overall decrease in open fracture density with depth results in a decreased groundwater flux with depth.

Topographic relief on the ORR is such that most active subsurface groundwater flow occurs at shallow depths. U.S. Geological Survey modeling (Tucci 1992) has suggested that $95 \%$ of all groundwater flow occurs in the upper 49 to $98 \mathrm{ft}(15$ to $30 \mathrm{~m})$ of the saturated zone in the ORR Aquitards. As a result, flow paths in the active-flow zones (particularly in the aquitards) are relatively short, and nearly all groundwater discharges to local surface water drainages on the ORR.

Conversely, in the Knox Aquifer it is believed that solution conduit flow paths could be considerably longer, perhaps as much as 1 mile $(1.6 \mathrm{~km})$ long in the along-strike direction. No evidence at this time substantiates the existence of any deep, regional flow off the ORR or between basins within the ORR in either the Knox Aquifer or the ORR Aquitards. Data collected in 1994 and 1995, however, have demonstrated that groundwater flow occurs off the ORR in the intermediate interval of the Knox Aquifer, near the east end of the Y-12 Complex. 


\section{CAVES, OPEN SINKHOLES, AND QUARRIES}

In addition to providing important habitat for some plants and animals, including sensitive species, the caves, sinkholes, and quarries on the ORR are often attractive to people, yet can be hazardous. The numerous caves on the reservation are not open to the public; access is restricted to research and monitoring uses. A large, open sinkhole is located near the Highway 95 entrance to the Tower Shielding Facility, in an area maintained by periodic mowing. The sinkhole is fenced, and access is restricted. The area is not open to the public. The three inactive quarries (Lambert, Kerr Hollow, and Rogers) are all in restricted areas and not open to the public.

\section{VEGETATION AND WILDLIFE}

Most of the ORR is relatively pristine when compared with the surrounding region, especially in the Valley and Ridge Physiographic Province (Mann et al. 1996). Viewed from the air, the ORR is clearly a large and nearly continuous island of forest within a landscape fragmented by urban development and agriculture. Many ecological communities (e.g., cedar barrens, river bluffs, and wetlands) with unique biota, often including rare species, are known to exist within the larger framework of mixed hardwood and pine forest on the ORR (Pounds, Parr, and Ryon 1993).

The ORR is mostly contiguous native eastern deciduous forest. Prior to their government acquisition as a security buffer for military activities, the approximately 1000 individual farmsteads in the area now included in the ORR consisted of forest, woodlots, open grazed woodlands, and fields. Results of remote-sensing analyses show that in 1994 about 70\% of the ORR was in forest cover and about $20 \%$ was transitional, consisting of old fields, agricultural areas, cutover forestlands, roadsides, and utility corridors (Washington-Allen et al. 1995). Forested areas (hardwood and pine, with many areas in blocks greater than 100 acres [ $40 \mathrm{ha}$ ]) are found throughout the reservation. Less than $2 \%$ of the reservation remains as open agricultural fields (Mann et al. 1996). Pine-beetle outbreaks during 1993 to 1994 and 1999 to 2000 impacted more than half the approximately 9500 acres (3840 ha) of planted and natural ORR pine stands. These areas have now naturally regenerated (only a few were replanted) as pine or hardwood stands. ORR forests are mostly oak-hickory, pine-hardwood, or pine. Minor areas of other hardwood-forest cover types are found throughout the ORR, including northern hardwoods, a few small natural stands of hemlock or white pine, and floodplain forests. Figure 8 shows ORR forests by forest groupings based on forestry compartment maps from the 1980s.

Over 1100 vascular plant species are found on the ORR (compared to the approximately 1650 species of the Great Smoky Mountains National Park, the most biologically diverse with respect to vascular plants of all the national parks in the contiguous United States). A list of vascular plants found on the ORR is found in Table A in Appendix A. This list, with additional detail, is also available at www.esd.ornl.gov/facilities/nerp. Twenty-one plants listed by the state as rare (endangered, threatened, or special concern) are found on the ORR (Awl et al. 1996; DOE 2005). The population of tall larkspur on the ORR is one of the largest populations known to occur anywhere in the world. The species is listed as globally rare by the Nature Conservancy and endangered by the state of Tennessee (Table 1).

This large, relatively unfragmented area of mature eastern deciduous hardwood forest provides habitat for numerous wildlife species. Such blocks of forested area are increasingly uncommon in the Valley and Ridge Physiographic Province and nationwide. In addition to the forested habitats and pine plantations, the ORR contains seminatural grasslands (e.g., hay) and forest edge (e.g., transmission line corridors through forest) that provide the diversity of habitats suitable for a great variety of wildlife. Other wildlife habitats on the ORR include old-field successional areas; unique or important vegetational communities such as cedar barrens and old-growth forests; seminatural 


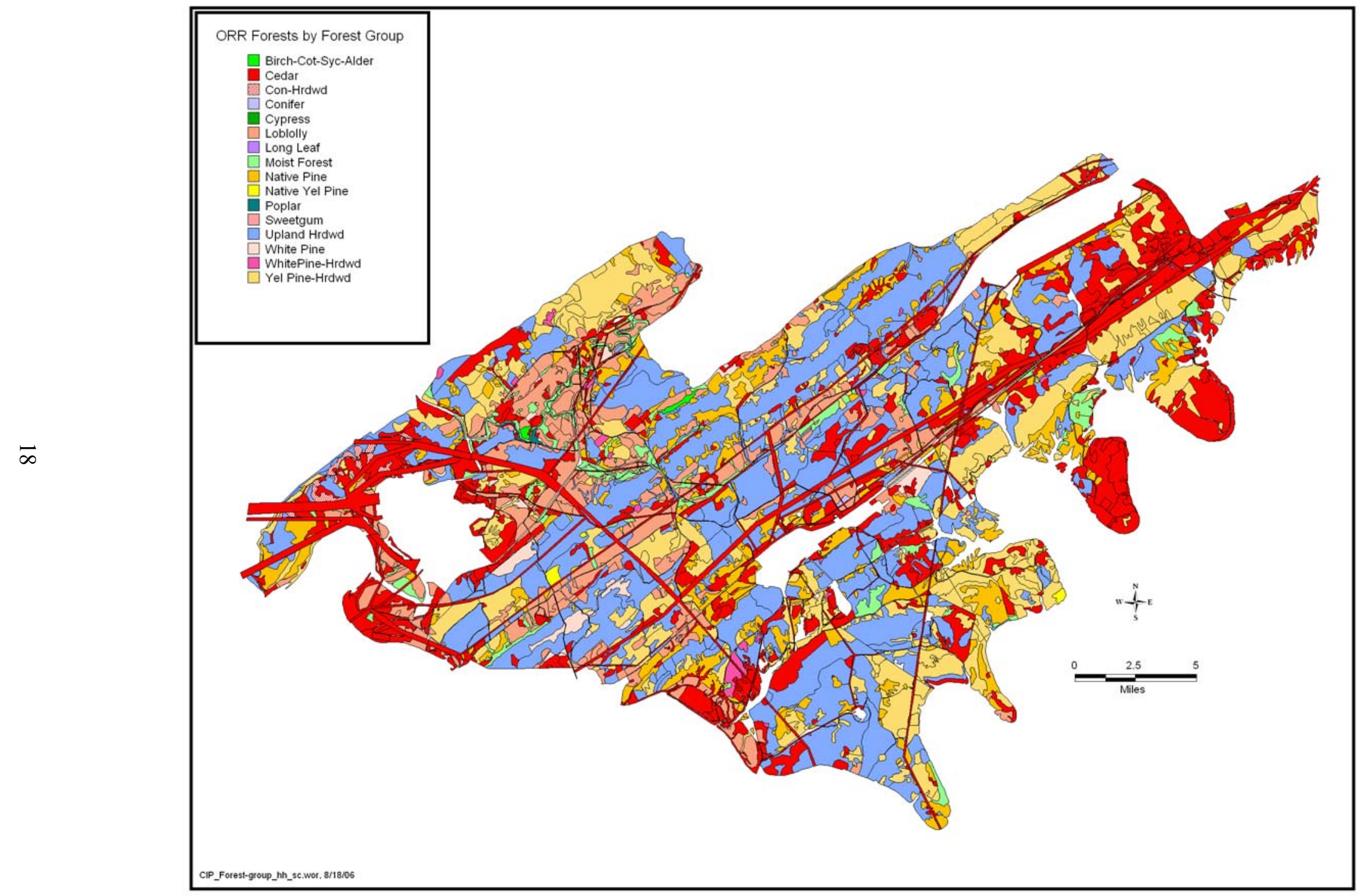

Fig. 8. ORR forests by forest groupings. 
Table 1. Vascular plant species on the ORR listed by state or federal agencies in 2006

\begin{tabular}{|c|c|c|c|}
\hline Species & Common name & Habitat on the ORR & $\begin{array}{l}\text { Status } \\
\text { code }^{a}\end{array}$ \\
\hline \multicolumn{4}{|c|}{ Currently known or previously reported from the ORR } \\
\hline Aureolaria patula & Spreading false-foxglove & River bluff & FSC, T \\
\hline Carex gravida & Heavy sedge & Varied & $\mathrm{S}$ \\
\hline Carex oxylepis var. pubescens ${ }^{b}$ & Hairy sharp-scaled sedge & Shaded wetlands & $\mathrm{S}$ \\
\hline Cimicifuga rubifolia & Appalachian bugbane & River slope & FSC, T \\
\hline Cypripedium acaule & Pink lady’s-slipper & Dry to rich woods & $\mathrm{E}, \mathrm{CE}$ \\
\hline Delphinium exaltatum & Tall larkspur & Barrens and woods & FSC, E \\
\hline Diervilla lonicera & Northern bush-honeysuckle & River bluff & $\mathrm{T}$ \\
\hline Draba ramosissima & Branching whitlow-grass & Limestone cliff & $\mathrm{S}$ \\
\hline Elodea nuttallii & Nuttall waterweed & Pond, embayment & $\mathrm{S}$ \\
\hline Fothergilla major & Mountain witch-alder & Woods & $\mathrm{T}$ \\
\hline Hydrastis canadensis & Golden seal & Rich woods & $\mathrm{S}, \mathrm{CE}$ \\
\hline Juglans cinerea & Butternut & Slope near stream & FSC, T \\
\hline Juncus brachycephalus & Small-head rush & Open wetland & $\mathrm{S}$ \\
\hline Lilium canadense & Canada lily & Moist woods & $\mathrm{T}$ \\
\hline Lilium michiganense $e^{c}$ & Michigan lily & Moist woods & $\mathrm{T}$ \\
\hline Liparis loeselii & Fen orchid & Forested wetland & $\mathrm{E}$ \\
\hline Panax quinquifolius & Ginseng & Rich woods & $\mathrm{S}, \mathrm{CE}$ \\
\hline Platanthera flava var. herbiola & Tuberculed rein-orchid & Forested wetland & $\mathrm{T}$ \\
\hline Populus grandidentata ${ }^{d}$ & Large-tooth aspen & Dry, woodlands & $\mathrm{S}$ \\
\hline Ruellia purshiana & Pursh's wild-petunia & Dry, open woods & $\mathrm{S}$ \\
\hline Scirpus fluviatilis & River bulrush & Wetland & $\mathrm{S}$ \\
\hline Spiranthes lucida & Shining ladies-tresses & Boggy wetland & $\mathrm{T}$ \\
\hline Thuja occidentalis & Northern white cedar & Rocky river bluffs & $\mathrm{S}$ \\
\hline Viola tripartita var. tripartita & Three-parted violet & Rocky woods & $\mathrm{S}$ \\
\hline \multicolumn{4}{|c|}{ Rare plants that occur near and could be present on the ORR } \\
\hline Agalinis auriculata & Earleaf false foxglove & Calcareous barren & FSC, E \\
\hline Allium burdickii or A. tricoccom ${ }^{e}$ & Ramps & Moist woods & $\mathrm{S}, \mathrm{CE}$ \\
\hline Berberis canadensis & American barberry & Rocky bluff, creek bank & $\mathrm{S}$ \\
\hline Gnaphalium helleri & Catfoot & Dry woodland edge & $\mathrm{S}$ \\
\hline Lathyrus palustris & A vetch & Moist meadows & $\mathrm{S}$ \\
\hline Liatris cylindracea & Slender blazing star & Calcareous barren & $\mathrm{E}$ \\
\hline Lonicera dioica & Mountain honeysuckle & Rocky river bluff & $\mathrm{S}$ \\
\hline Meehania cordata & Heartleaf meehania & Moist calcareous woods & $\mathrm{T}$ \\
\hline Pedicularis lanceolata & Swamp lousewort & Calcareous wet meadow & $\mathrm{T}$ \\
\hline Pycnanthemum torrei & Torrey's mountain-mint & Calcareous barren edge & $\mathrm{S}$ \\
\hline Solidago ptarmicoides & Prairie goldenrod & Calcareous barren & $\mathrm{E}$ \\
\hline \multicolumn{4}{|l|}{${ }^{a}$ Status codes: } \\
\hline \multicolumn{4}{|c|}{ Status due to commercial exploitation. } \\
\hline \multicolumn{4}{|c|}{ Endangered in Tennessee. } \\
\hline \multicolumn{4}{|c|}{ Federal special concern; formerly designated as C2. See Federal Register, February 28,1996. } \\
\hline \multicolumn{4}{|c|}{ Special concern in Tennessee. } \\
\hline \multicolumn{4}{|c|}{ Threatened in Tennessee. } \\
\hline \\
\hline \\
\hline \multicolumn{4}{|c|}{$\begin{array}{l}{ }^{c} \text { Lilium michiganense is believed to have been extirpated from the ORR by the impoundment at Melton Hill. } \\
{ }^{d} \text { Populus grandidentata was reported in two ORR locations in } 2003 \text {. One of the reports was confirmed, but the }\end{array}$} \\
\hline \multicolumn{4}{|c|}{ tree died during the year. In 2004 additional trees were found in the vicinity of the dead tree. } \\
\hline \multicolumn{4}{|c|}{${ }^{e}$ Ramps have been reported near the ORR, but there is not sufficient information to determine which of the two } \\
\hline
\end{tabular}


corridors; planted hardwoods and pines; bottomlands and wetlands, including an increasing number of beaver ponds; caves; and developed and semideveloped areas and roads.

The resulting diversity of wildlife species ranges from common species found in urban and suburban areas of eastern Tennessee to species with more restrictive requirements, such as interior forest bird species. The ORR hosts more than 70 species of fish; about 45 species of reptiles and amphibians; more than 200 species of migratory, transient, and resident birds; and more than 30 species of mammals, as well as innumerable invertebrate species. Tables B.1, B.2, and B.3 list the fish; reptiles, amphibians, and mammals; and birds found on the ORR. Among these, 17 species of federally or state-listed (endangered, threatened, or in need of management) vertebrate species have been confirmed in recent surveys (Mitchell et al. 1996). Furthermore, appropriate habitat for approximately 20 additional species has been identified. In addition, 13 of the recorded bird species are listed by Partners in Flight as species of concern. Monitoring by Partners in Flight has also determined that 11 of the 16 species that are of top conservation priority in the region are present on the reservation during the breeding season. Table 2 lists the animals of special concern on the ORR. Updated information on ORR wildlife is maintained online at the Research Park's Web site, www.esd.ornl.gov/facilities/nerp.

The Tennessee dace (listed by the state as in need of management) is found in numerous streams and tributaries on the reservation, in contrast to declining or absent populations in streams outside the ORR.

Listed rare species (plants and wildlife) occur across the ORR in more than 50 different locations, which are protected as Research Park Natural Areas. As a result of urbanization, many of these Research Park Natural Areas contain plants or animals now absent from or uncommon in areas surrounding the ORR.

\section{INTERIOR FOREST RESOURCES}

The ORR's extensive forest area, amounting to approximately 24,000 acres $(9,712 \mathrm{ha})$, is valuable not only for its size, but also because of its many batches of forest larger than 50 contiguous acres (20 ha) (Fig. 9). Contiguous forest provides habitat for several plant and animal species not associated with smaller patches of forest. This is especially true for certain increasingly rare bird species. Deep forest habitat is located away from large openings and typically has more than $70 \%$ canopy cover. A minimum of 50 contiguous acres ( $20 \mathrm{ha}$ ) of forest habitat can be used as a benchmark as the required acreage for the presence of many deep forest wildlife species.

As human populations continue to increase and expand, large tracts of contiguous forest are becoming smaller and are broken into a greater number of pieces. Forest area is lost to clearing of land for industry, agriculture, and residential development, and the remaining forest is further fragmented by associated roads and utility corridors. Fragmentation creates an "edge effect" that alters habitat conditions such as moisture regime, microclimate, and light penetration and can result in the introduction and spread of predators harmful to forest-dependent species. Nesting forest birds increasingly fall prey to predators associated with edge habitat such as feral cats, raccoons, and certain snake species. The creation of cleared areas throughout forests also opens the area to the brown-headed cowbird, a common nest parasite that uses edge habitat and parasitizes nests of forest birds. Cowbirds fly in from the edges to lay their eggs in the nests of forest birds, where the larger more aggressive cowbird young out-compete the fledglings of the forest-bird species. As more edges are created through the forest, cowbird penetration and associated nest predation on forest species such as wood thrush increase. 
Table 2. Animal species of concern reported on the $\mathrm{ORR}^{a, b}$

\begin{tabular}{|c|c|c|c|c|}
\hline \multirow{2}{*}{ Scientific name } & \multirow{2}{*}{ Common name } & \multicolumn{3}{|c|}{ Status $^{c}$} \\
\hline & & Federal & State & PIF $^{d}$ \\
\hline \multicolumn{5}{|c|}{ Fish } \\
\hline Phoxinus tennesseensis & Tennessee dace & & NM & \\
\hline \multicolumn{5}{|c|}{ Amphibians and reptiles } \\
\hline Hemidactylium scutatum & Four-toed salamander & & NM & \\
\hline \multicolumn{5}{|c|}{ Birds } \\
\hline Accipiter striatus & Sharp-shinned hawk & & NM & \\
\hline Anhinga anhinga & Anhinga & & NM & \\
\hline Caprimulgus carolinensis & Chuck-will's widow & & & $\mathrm{C}$ \\
\hline Ardea alba & Great egret & & NM & \\
\hline Circus cyaneus & Northern harrier & & NM & \\
\hline Contopus cooperi & Olive-sided flycatcher & & NM & \\
\hline Dendroica caerulescens & Black-throated blue warbler & & & $\mathrm{C}$ \\
\hline Dendroica cerulea & Cerulean warbler & & NM & $\mathrm{C}$ \\
\hline Dendroica discolor & Prairie warbler & & & $\mathrm{C}$ \\
\hline Egretta caerulea & Little blue heron & & $\mathrm{NM}$ & \\
\hline Egretta thula & Snowy egret & & NM & \\
\hline Falco peregrinus & Peregrine falcon & $e$ & $\mathrm{E}$ & \\
\hline Haliaeetus leucocephalus & Bald eagle & $\mathrm{T}^{f}$ & NM & \\
\hline Helmitheros vermivorus & Worm-eating warbler & & & $\mathrm{C}$ \\
\hline Hylocichla mustelina & Wood thrush & & & $\mathrm{C}$ \\
\hline Lanius ludovicianus & Loggerhead shrike & & NM & \\
\hline Oporornis formosus & Kentucky warbler & & & $\mathrm{C}$ \\
\hline Pooecetes gramineus & Vesper sparrow & & NM & \\
\hline Protonotaria citrea & Prothonotary warbler & & & $\mathrm{C}$ \\
\hline Seiurus motacilla & Louisiana waterthrush & & & $\mathrm{C}$ \\
\hline Sitta pusilla & Brown-headed nuthatch & & & $\mathrm{C}$ \\
\hline Sphyrapicus varius & Yellow-bellied sapsucker & & NM & \\
\hline Spizella pusilla & Field sparrow & & & $\mathrm{C}$ \\
\hline Tyto alba & Barn owl & & NM & \\
\hline Vermivora chrysoptera & Golden-winged warbler & & NM & $\mathrm{C}$ \\
\hline Vermivora pinus & Blue-winged warbler & & & $\mathrm{C}$ \\
\hline \multicolumn{5}{|c|}{ Mammals } \\
\hline Myotis grisescens & Gray bat & $\mathrm{E}$ & $\mathrm{E}$ & \\
\hline Sorex longirostris & Southeastern shrew & & NM & \\
\hline
\end{tabular}

${ }^{a}$ This list identifies sensitive wildlife species recently found on the ORR. Some of these (e.g., anhinga) have been seen only once or a few times; others (e.g., sharp-shinned hawk, southeastern shrew) are comparatively common and widespread on the reservation (updated December 2005).

${ }^{b}$ Land and surface waters of the ORR exclusive of the Clinch River, which borders the ORR.

${ }^{c} \mathrm{C}=$ birds of concern, $\mathrm{E}=$ endangered, $\mathrm{NM}=$ in need of management, $\mathrm{T}=$ threatened.

${ }^{d}$ Partners in Flight.

${ }^{e}$ The peregrine falcon was federally delisted on August 25, 1999.

${ }^{f}$ The bald eagle was proposed for federal delisting on July 6, 1999 . 


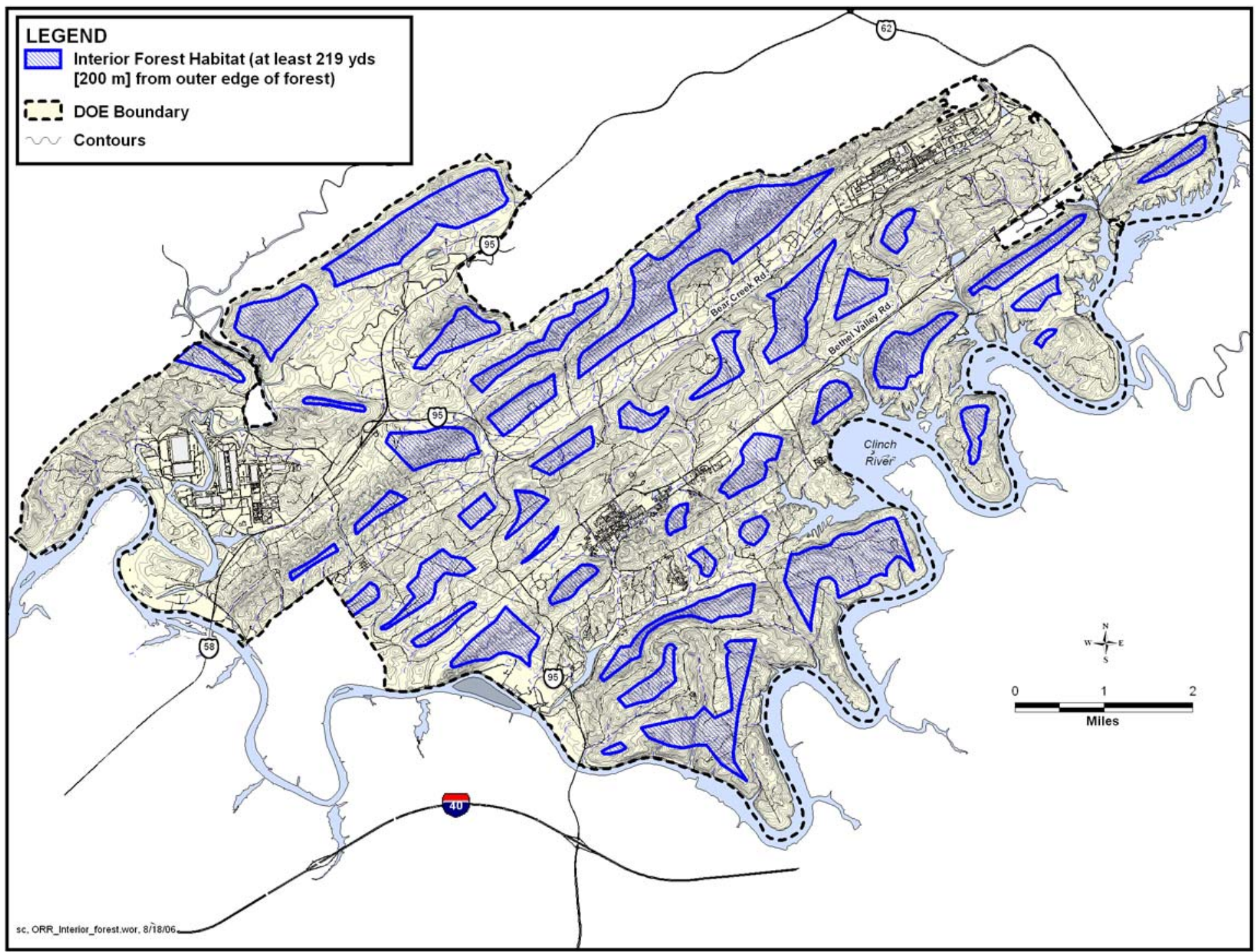

Fig. 9. Interior forest habitat on the ORR. 
Studies conducted by wildlife biologist Stanley Temple indicate that the edge effect extends into a forest as much as $219 \mathrm{yd}(200 \mathrm{~m})$ (Temple and Cary 1988). Thus, researchers have used this distance as a criterion for identifying "interior" forest areas that would remain unaffected by forest fragmentation. When the 219-yd (200-m) buffer area is taken into consideration, the true nonimpacted interior forest could be eliminated or reduced to very small and/or narrow areas when encroached upon by surrounding roads, power-line corridors, and other openings. The ORR currently supports about 4100 acres (1659 ha) of interior forest. This acreage will decrease in certain areas of the reservation with additional clearing for new buildings and new roads and as a result of further roadwidening projects.

An important barometer in the determination of forest habitat quality is the presence of certain neo-tropical migrant bird species. These species are impacted by decreases in acreage and the fragmentation of forest habitats. Fortunately, the ORR continues to support many such species, including the Acadian flycatcher, ovenbird, hooded warbler, northern parula, Kentucky warbler, and Louisiana water thrush.

Continued fragmentation of forest habitat on the ORR will result in the loss of species such as those noted above. Exercising care concerning road placement, minimizing road widenings, and allowing the forest canopy to close over existing roads will help mitigate impacts on interior forest resources.

\section{WETLANDS}

The ecological functioning of approximately 580 acres (235 ha) of wetlands known to date on the ORR provides water-quality benefits, stormwater control, wildlife habitat, rare-species habitat, and landscape and biological diversity (Fig. 6).

Wetlands occur across the ORR at low-elevation positions, primarily in the riparian zones of headwater streams and their receiving streams, as well as in Clinch River embayments. Most of the wetlands on the ORR are classified as palustrine forested, scrub-shrub, and emergent wetlands (Cowardin et al. 1979). Wetlands identified to date range in size from several square yards at small seeps and springs to approximately 25 acres (10 ha) at White Oak Lake. A high percentage of the wetlands on the ORR encompass less than 1 acre $(1 / 2 \mathrm{ha})$ and occur in headwater areas. Wetlands greater than 1 acre ( 0.4 ha) are typically associated with river embayments, other areas affected by the fluctuating water levels of the Clinch River reservoirs (e.g., Poplar Creek), areas in which water has been artificially impounded (e.g., White Oak Lake), and beaver ponds.

Activities that affect wetlands are regulated under federal law (Sect. 404 of the Clean Water Act, Federal Water Pollution Control Act, 33 USC 1251) and state law (Tennessee Water Quality Control Act, TN Code Annotated 70-324). Federal and state permits are required to conduct dredge-and-fill activities in a jurisdictional wetland (i.e., an area that meets the criteria established by the U.S. Army Corps of Engineers for a wetland). Impacts to wetlands are avoided whenever possible. If impacts are unavoidable, they are minimized through steps such as project design changes or the implementation of best management practices. Compensatory mitigation in the form of wetland restoration, creation, or enhancement is a required permit condition under certain circumstances.

\section{CULTURAL RESOURCES}

Cultural resources on the ORR include (1) surface and buried archaeological materials (artifacts) and sites dating to the prehistoric, historic, and ethnohistoric periods; (2) standing structures that are more than 50 years old or, if newer, are important because they represent a major historical theme or era; (3) cultural and natural places, selected natural resources, and objects with importance for Native Americans; and (4) American folklife traditions and arts. Six properties on the ORR are included in the National Register of Historic Places: (1) Oak Ridge Turnpike Checking Station, (2) Bear Creek 
Road Checking Station, (3) New Bethel Baptist Church, (4) George Jones Memorial Baptist Church (also known as Wheat Church), (5) Freels Cabin, and (6) the ORNL Graphite Reactor. Figure 10 shows the general locations of registered historic places, cemeteries, churches, a national historic landmark, and old home structures. Many other sites on the ORR, both historic and archaeological, have been determined to be eligible for listing in the National Register of Historic Places. The X-10 Graphite Reactor at ORNL was also designated as a national historic landmark on December 21, 1965 , based on the national and international significance of its contributions to science and technology.

\section{SPECIAL DESIGNATIONS}

The ORR has evolved into a biologically rich resource over the last 60 years (see Chap. 8).

The combination of long-term protection for the land area and the biological richness of the ORR with the available research capability and proximity of diverse scientific expertise has resulted in the following state, regional, national, and international designations:

- the DOE National Environmental Research Park,

- ParkNet (a network of seven DOE National Environmental Research Parks),

- the National Environmental Research Park Biosphere Reserve,

- a unit of the Southern Appalachian Biosphere (with the Great Smoky Mountains National Park, Coweeta Hydrologic Laboratory, and others),

- the Southern Appalachian Man and the Biosphere Cooperative (with the U.S. Department of Agriculture; TVA; the Economic Development Administration; EPA, Region IV; the U.S. Fish and Wildlife Service; the U.S. Geological Survey; the National Park Service; the U.S. Forest Service; and the states of Tennessee, North Carolina, and Georgia),

- Oak Ridge Wildlife Management Area, managed by the Tennessee Wildlife Resources Agency (TWRA),

- the Three Bend Scenic and Wildlife Management Refuge Area,

- the Black Oak Ridge Conservation Easement Area, and

- the DOE National Environmental Research Park User Facility.

Figure 11 shows land management and operational uses on the ORR, including special designations.

\subsection{OAK RIDGE WILDLIFE MANAGEMENT AREA}

The entire ORR is a Tennessee Wildlife Management Area (Fig. 11) through an agreement between DOE and TWRA. The agreement provides for protection of wildlife habitat and species (including several threatened and endangered species) and restoration of other wildlife habitat and species. Management of the ORR for wildlife is also a type of land use.

About 2920 acres (1182 ha) of the Oak Ridge Wildlife Management Area are specifically managed by TWRA under a separate agreement with DOE. This area is known as the Three Bend Scenic and Wildlife Management Refuge Area and includes most of Solway, Freels, and Gallaher Bends along the Clinch River on the southern boundary of the ORR (Fig. 11).

Approximately 3000 acres (1214 ha) in the northwestern part of the ORR were placed in a conservation easement in April 2005. TWRA manages the land in accordance with a plan developed jointly by the Tennessee Department of Environment and Conservation (TDEC) and TWRA with 


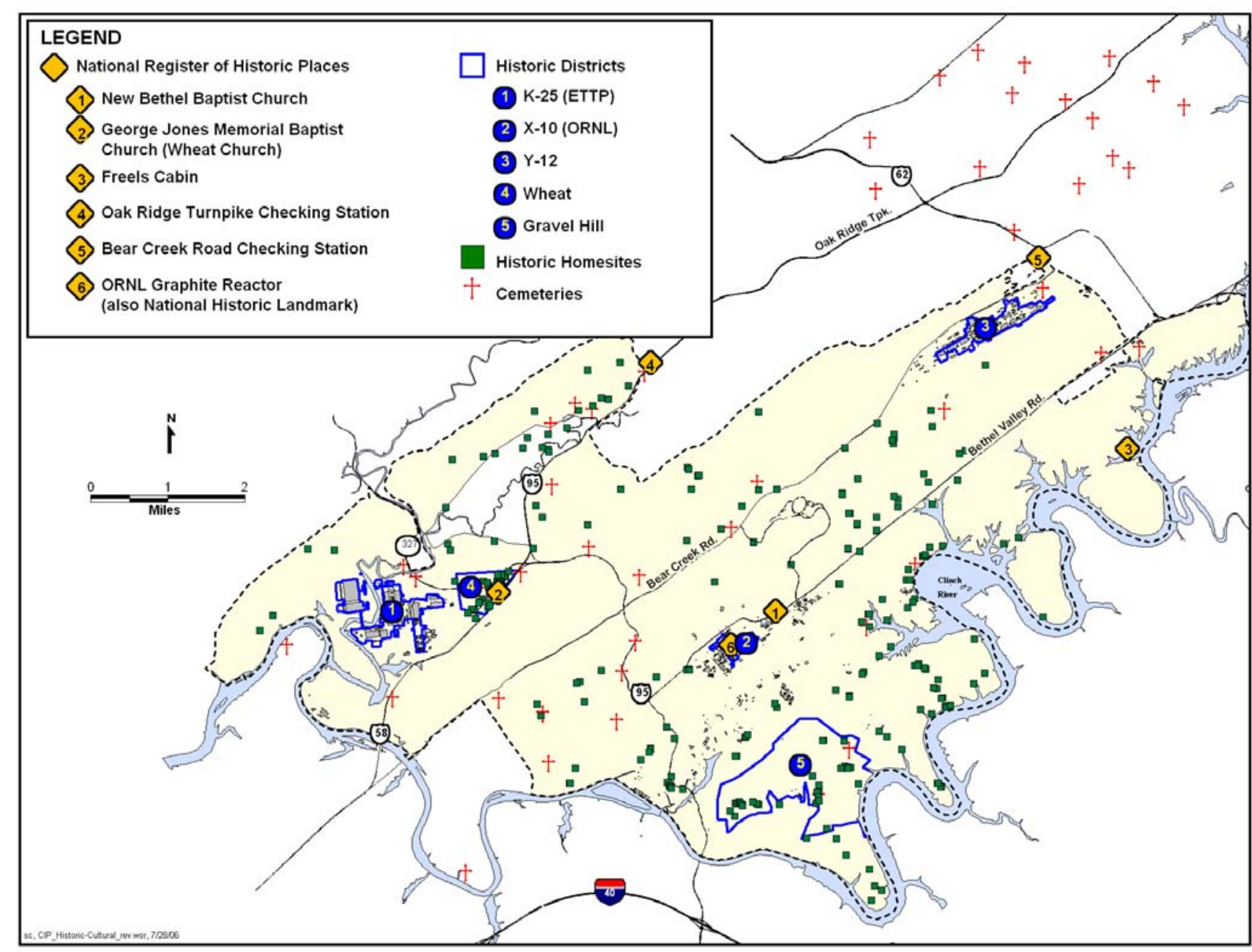

Fig. 10. Historic and cultural resources of the ORR. 


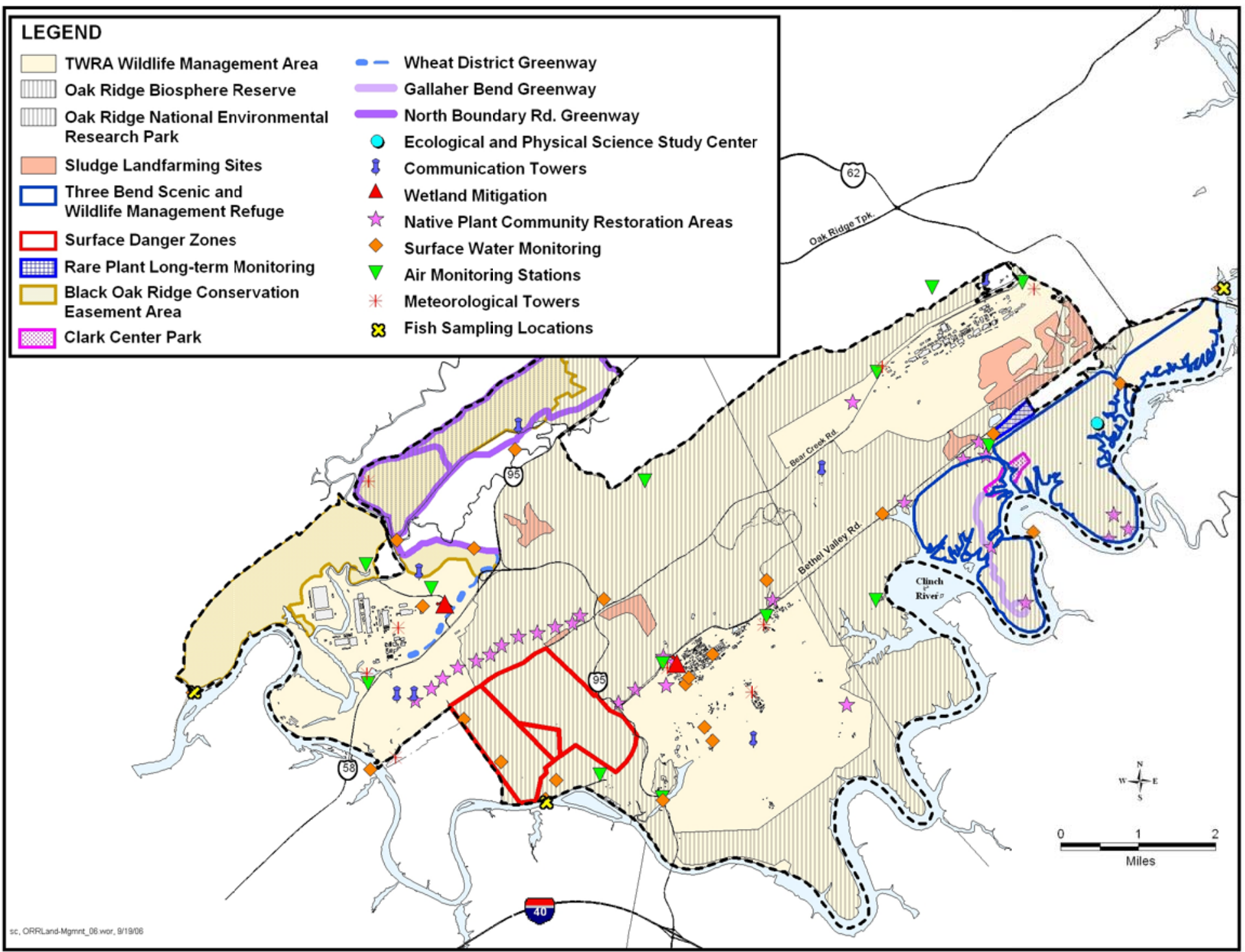

Fig. 11. Land management and operational uses on the ORR. 
input from the public. The agreement enables DOE to assist in paying for natural resource damages at the Lower Watts Bar reservoir caused by DOE's activities on the ORR.

\subsection{NATURE CONSERVANCY BIODIVERSITY RANKED AREAS}

More than 270 occurrences of significant plant and animal species were recognized by The Nature Conservancy in its report of biodiversity on the ORR as part of Common Ground, the DOE Future Land Use Initiative (The Nature Conservancy 1995). In addition, using a national ranking system, The Nature Conservancy identified more than 69 preliminary conservation sites with occurrences of rare species and communities and other important features (e.g., caves, springs). These sites generally had clusters of important species or communities, with special emphasis placed on those species and elements designated as globally imperiled, rare, or uncommon in The Nature Conservancy and Natural Heritage Network ranking system. The sites also include the landscape features and ecological processes (i.e., watersheds) believed to be important for sustaining the occurrences of important species and communities.

The sites were evaluated and given a biological significance ranking (BSR) based on their conservation significance. Sites on the ORR were rated BSR-2 (very high significance), BSR-3 (high significance), and BSR-4 (moderate significance). The BSR-5 category (of general biodiversity interest) was not used in The Nature Conservancy's report, although it notes that "forested land on ORR would fit in this or an above category." The Nature Conservancy areas of biological significance are identified in Fig. 12. The Nature Conservancy maintains ORR records of rare plant and animal species in the Biological and Conservation Database.

\subsection{NATURE CONSERVANCY LANDSCAPE COMPLEXES}

The Nature Conservancy report also recommended protection of three large land areas (Fig. 12) on which are found many highly ranked conservation sites (i.e., those with rare communities and rare species, hardwood forests greater than 100 acres [40.5 ha] and critical watersheds) (The Nature Conservancy 1995).

\subsection{RESEARCH PARK ENDANGERED SPECIES HABITATS (NATURAL AREAS)}

Rare plant and animal species (state and/or federal candidate and/or listed) are provided protection through preservation of the habitat that is required for their survival. Such important habitat is established on the best available information about the need of the rare species and is protected through Research Park Natural Area designations. Figure 13 shows the ORR areas designated as habitat for rare species.

\subsection{RESEARCH PARK ENDANGERED SPECIES POTENTIAL HABITATS (REFERENCE AREAS)}

Reference areas serve two functions. They provide protection to habitat with high potential for rare plant or animal species while also protecting common or representative plant or animal communities that can serve as baseline areas for research and monitoring. Many of the areas originally designated as Research Park Reference Areas have been found to contain rare plant or animal species and have been assigned the Research Park Natural Area designation. Figure 13 shows these areas as potential habitat for rare species. 


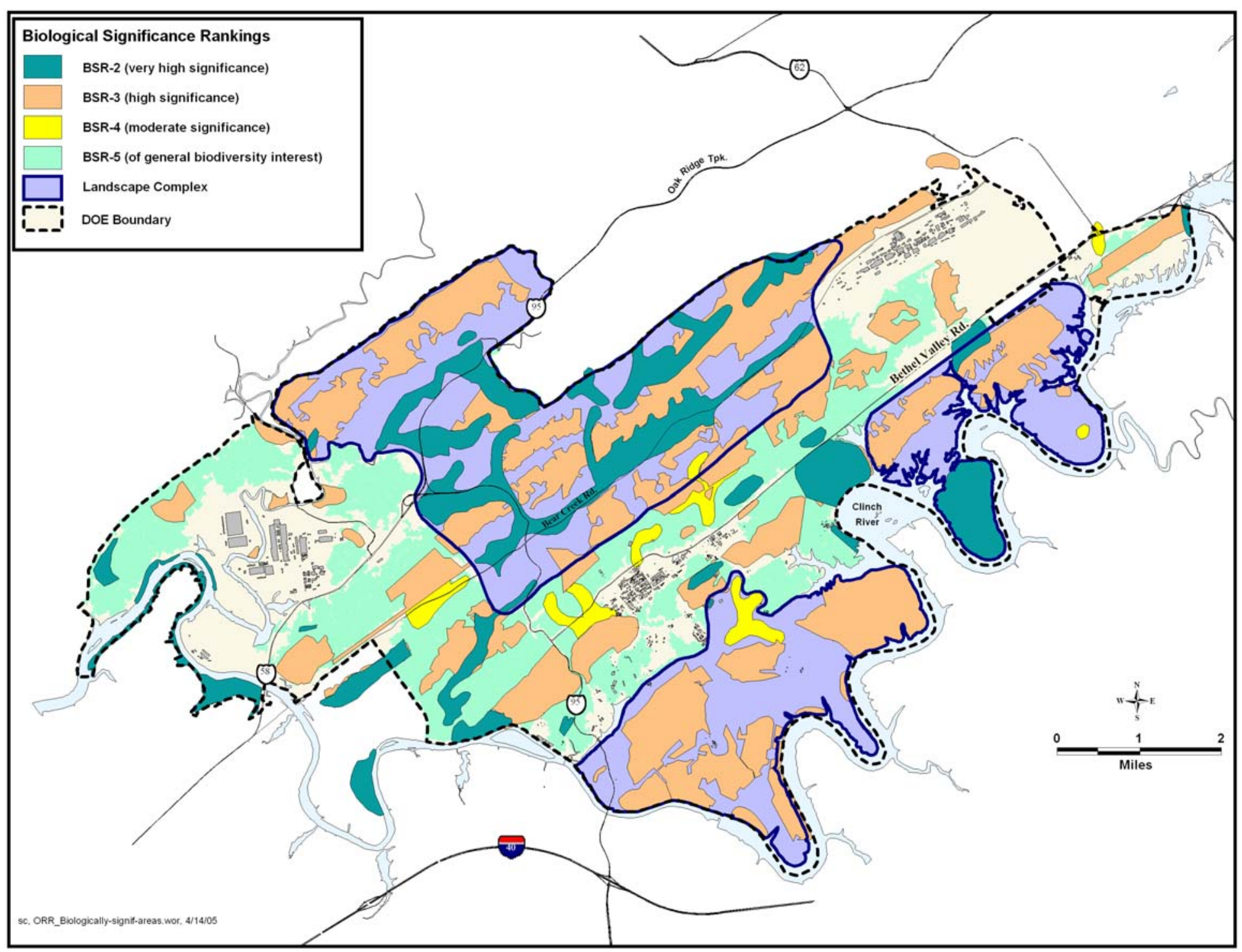

Fig. 12. Biologically significant areas on the ORR. 


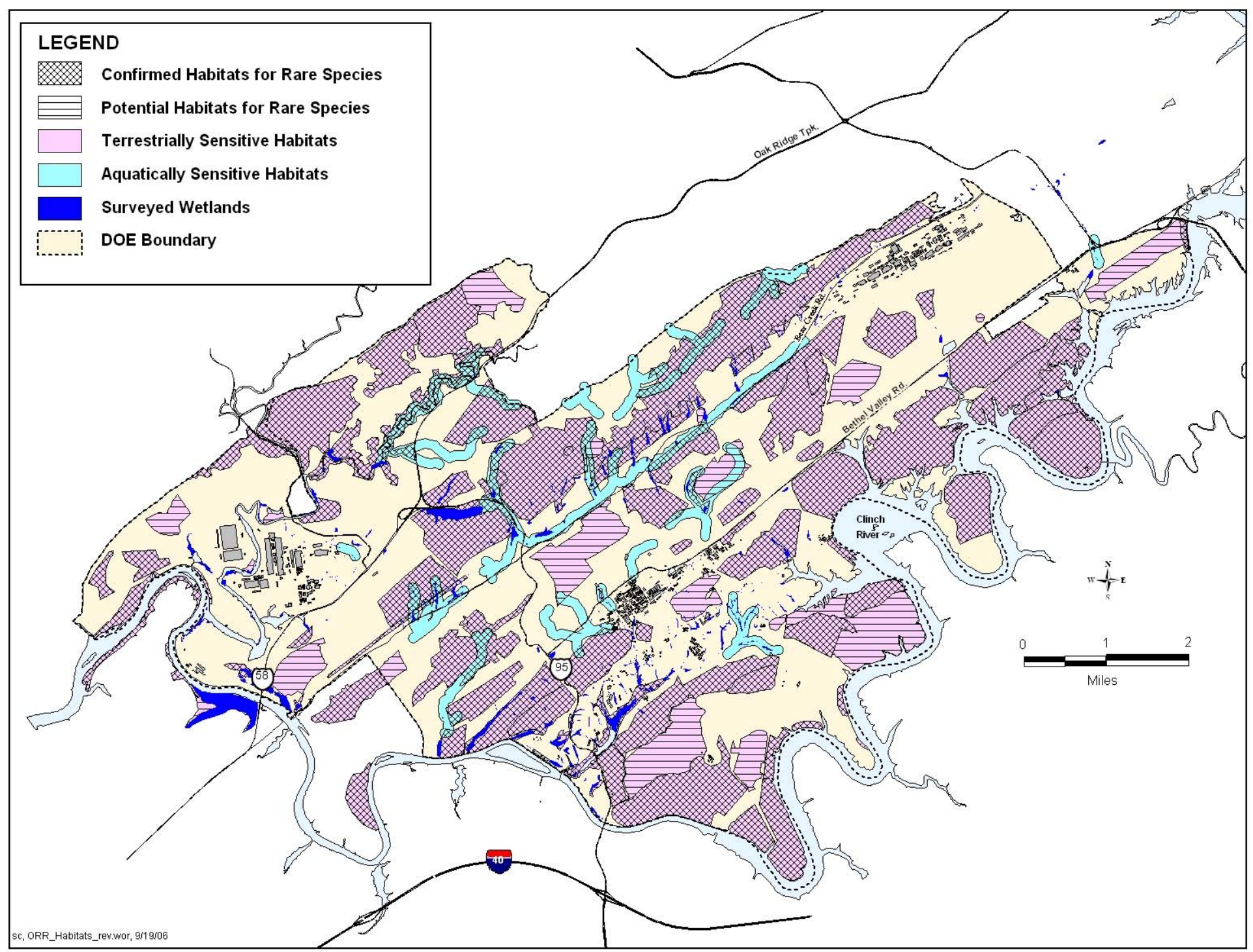

Fig. 13. Confirmed and potential habitats for rare plants and wildlife on the ORR. 


\subsection{BIOSPHERE RESERVE}

The Oak Ridge National Environmental Research Park Biosphere Reserve was designated in 1988 (see Fig. 11). Biosphere reserves are areas of terrestrial and coastal ecosystems that are internationally recognized within the framework of the United Nations Educational, Scientific, and Cultural Organization Man and the Biosphere (MAB) Program. Collectively, they constitute a MAB World Network. Each biosphere reserve is encouraged to fulfill three functions, as appropriate, within its management framework: (1) a conservation function (contributing to the conservation of landscapes, ecosystems, species, and genetic variation), (2) a development function (fostering economic and human development that is socioculturally and ecologically sustainable), and (3) a logistic function (providing support for research, monitoring, education, and information exchange related to local, national, and global issues of conservation and development). The Oak Ridge National Environmental Research Park Biosphere Reserve is managed by ORNL for DOE. In addition, the Oak Ridge National Environmental Research Park Biosphere Reserve is a unit within the regional zone of the Southern Appalachian Biosphere Reserve. The MAB World Network is comprised of more than 360 biosphere reserves. The Southern Appalachian Man and the Biosphere Program is one of the most active of 47 U.S. biosphere reserves and is regarded as an international model.

\section{REFERENCES}

Awl, D. J., L. R. Pounds, B. A. Rosensteel, A. L. King, and P. A. Hamlett. 1996. Survey of Protected Vascular Plants on the Oak Ridge Reservation. ES/ER/TM-194, Oak Ridge National Laboratory, Environmental Restoration Division, Oak Ridge, TN. June.

Birdwell, K. R. 1996. "A Climatology of Winds over a Ridge and Valley Terrain within the Great Valley of Eastern Tennessee.” Master's thesis, Murray State University, Department of Geosciences, Murray, KY.

Bowen, B. 2001. Tennessee Department of Environment and Conservation, letter to Leah Dever, Department of Energy Oak Ridge Operations Manager, June 18.

Carlson, M. A., and R. B. Stull. 1986. "Subsidence in the Nocturnal Boundary Layer." Journal of Climate and Applied Meteorology 25, 1088-99.

Cowardin, L. M., V. Carter, F. C. Golet, and E. T. LaRoe. 1979. Classification of Wetlands and Deepwater Habitats of the United States. FWS/OBS-79/31, U.S. Fish and Wildlife Service, Washington, D.C.

DOE (U.S. Department of Energy). 2005. Oak Ridge Reservation Annual Site Environmental Report for 2004. DOE/ORO/2204, Oak Ridge, TN, September.

Eckman, R. M. 1998. "Observations and Numerical Simulations of Winds within a Broad Forested Valley." Journal of Applied Meteorology 37, 206-19.

Farnsworth, R. K., E. S. Thompson, and E. L. Peck. 1982. Evaporation Atlas for the Contiguous 48 United States. NOAA Technical Report NWS 33, National Weather Service Office of Hydrology, Washington, D.C. 
Hatcher, R. D., et al. 1989. Field Guide and Perspective on the Geology and Hydrology of the Oak Ridge Reservation. Oak Ridge National Laboratory/University of Tennessee, Oak Ridge, TN.

Hatcher, R. D., Jr., P. J. Lemiski, R. B. Dreier, R. H. Ketelle, R. R. Lee, D. A. Lietzke, W. M. McMaster, J. L. Forman, and S. Y. Lee. 1992. Status Report on the Geology of the Oak Ridge Reservation. ORNL/TM-12074, Oak Ridge National Laboratory, Oak Ridge, TN.

Kossman, M., and A. P. Sturman. 2002. "Pressure Driven Channeling Effects in Bent Valleys." Journal of Applied Meteorology 42, 151-58.

Lewellen, D. C., and W. S. Lewellen. 2002. "Entrainment and Decoupling Relations for Cloudy Boundary Layers." Journal of the Atmospheric Sciences 59, 2966-86.

Mann, L. K., P. D. Parr, L. R. Pounds, and R. L. Graham. 1996. "Protection of Biota on Nonpark Public Lands: Examples from the U.S. Department of Energy Oak Ridge Reservation." Environmental Management 20, 207-18.

Mitchell, J. M., E. R. Vail, J. W. Webb, A. L. King, and P. A. Hamlett. 1996. Survey of Protected Terrestrial Vertebrates on the Oak Ridge Reservation. ES/ER/TM-188, Oak Ridge National Laboratory, Environmental Restoration Division, Oak Ridge, TN. May.

Monti, P., H. J. S. Fernando, M. Princevac, W. C. Chan, T. A. Kowalewski, and E. R. Pardyjak. 2002. "Observations of Flow and Turbulence in the Nocturnal Boundary Layer Over a Slope." Journal of the Atmospheric Sciences 59, 2513-34.

Moore, G. K. 1988. Concepts of Groundwater Occurrence and Flow Near Oak Ridge National Laboratory, Tennessee. ORNL/TM-10969, Martin Marietta Energy Systems, Inc., Oak Ridge, TN.

Nativ, R., A. Halleran, and A. Hunley. 1997. The Deep Hydrogeologic Flow System Underlying the Oak Ridge Reservation-Assessing the Potential for Active Groundwater Flow and Origin of the Brine. ORNL/GWPO-18, Oak Ridge National Laboratory, Oak Ridge, TN.

NOAA (National Oceanic and Atmospheric Administration). 2006. Local Climatological Data Annual Survey with Comparative Data, Oak Ridge, Tenn. National Oceanic and Atmospheric Administration, National Climatic Data Center, Asheville, NC.

Smith, R. B., S. Skubis, J. D. Doyle, A. S. Broad, C. Kiemle, and H. Volkert. 2002. "Mountain Waves Over Mont Blanc: Influence of a Stagnant Boundary Layer." Journal of the Atmospheric Sciences 59 (13), 2073-2092.

Temple, S. A., and J. R. Cary. 1988. "Modeling Dynamics of Habitat-Interior Bird Populations in Fragmented Landscapes." Conservation Biology 2, 340-47.

The Nature Conservancy. 1995. Oak Ridge Reservation, Biodiversity, and the Common Ground Process: Preliminary Biodiversity Report on the Oak Ridge Reservation. The Nature Conservancy, Arlington, VA.

Tucci, P. 1992. Hydrology of Melton Valley at Oak Ridge National Laboratory, Tennessee. U.S. Geological Survey Water Resources Investigation Report 92-4131, Nashville, TN. 
TVA (Tennessee Valley Authority). 1972. Upper Bear Creek Experimental Project: A Continuous Daily Streamflow Model. Research Paper No. 8, Tennessee Valley Authority Division of Water Control Planning, Knoxville, TN.

Van de Weil, B. J. H., A. F. Moene, R. J. Ronda, H. A. R. De Bruin, and A. A. M. Holtslag. 2002. "Intermittent Turbulence and Oscillations in the Stable Boundary Layer Over Land. Part II: A System Dynamics Approach.” Journal of the Atmospheric Sciences 59, 2567-81.

Washington-Allen, R. A., T. L. Ashwood, S. W. Christensen, H. Offerman, and P. ScarbroughLuther. 1995. Terrestrial Mapping of the Oak Ridge Reservation: Phase I. ES/ER/TM-152, Oak Ridge National Laboratory, Oak Ridge, TN.

Whiteman, C. D. 2000. Mountain Meteorology: Fundamentals and Applications. Oxford University Press, New York.

Whiteman, C. D., S. Zhong, W. J. Shaw, J. M. Hubbe, and X. Bian. 2001. "Cold Pools in the Columbia River Basin." Weather and Forecasting 16, 432-47. 
APPENDIX A

\section{PLANTS FOUND ON THE OAK RIDGE RESERVATION}



Table A. Vascular plants found on the Oak Ridge Reservation

\begin{tabular}{|c|c|c|c|c|c|}
\hline Genus & Species & Common name & Genus & Species & Common name \\
\hline Abutilon & theophrasti & Velvel leaf & Krigia & virginica & Virginia dwarf dandelion \\
\hline Acalypha & gracilens & Narrow-leaved three-seeded mercury & Kuhnia & eupatoriodes & False boneset \\
\hline Acalypha & rhomboidea & Three-seeded mercury & Kummerowia & stipulacea & Korean bush-clover \\
\hline Acalypha & virginica & Virginia three-seeded mercury & Kummerowia & striata & Japanese clover \\
\hline Acer & negundo & Box-elder & Kyllinga & gracillima & Pasture spike sedge \\
\hline Acer & rubrum & Red maple & Kyllinga & pumila & Low spike sedge \\
\hline Acer & saccharinum & Silver maple & Lactuca & canadensis & Wild lettuce \\
\hline Acer & saccharum & Sugar maple & Lactuca & floridana & Woodland blue lettuce \\
\hline Achillea & millefolium & Yarrow & Lactuca & saligna & Willow-leaved lettuce \\
\hline Aconitum & uncinatum & Monk's hood & Lactuca & serriola & Prickly lettuce \\
\hline Acorus & americanus & Sweet-flag & Lamium & amplexicaule & Henbit \\
\hline Actaea & pachypoda & Doll's eyes & Lamium & purpureum & Purple dead-nettle \\
\hline Adiantum & pedatum & Maidenhair fern & Lathyrus & latifolius & Everlasting pea \\
\hline Aesculus & flava & Yellow buckeye & Lechea & racemulosa & Pinweed \\
\hline Aesculus & sylvatica & Painted buckeye & Leersia & oryzoides & Rice cutgrass \\
\hline Agalinis & purpurea & Purple gerardia & Leersia & virginica & Virginia cutgrass \\
\hline Agalinis & tenuifolia & Slender gerardia & Lemna & minor & Duckweed \\
\hline Agastache & nepetoides & Yellow giant-hyssop & Leonurus & cardiaca & Motherwort \\
\hline Ageratina & altissima & White snakeroot & Lepidium & campestre & Cow-cress \\
\hline Ageratina & aromatica & - & Lepidium & virginicum & Poor man's pepper \\
\hline Agrimonia & parviflora & Southern agrimony & Lespedeza & bicolor & Shrubby bushclover \\
\hline Agrimonia & pubescens & Downy agrimony & Lespedeza & capitata & Round-headed bush-clover \\
\hline Agrimonia & rostellata & Woodland agrimony & Lespedeza & cuneata & Cuneate bus-clover \\
\hline Agrostemma & githago & Corncockle & Lespedeza & hirta & Hairy bush-clover \\
\hline Agrostis & hyemalis & Hairgrass & Lespedeza & intermedia & - \\
\hline Agrostis & perennans & Upland bentgrass & Lespedeza & procumbens & Low bush-clover \\
\hline Agrostis & stolonifera & Creeping bentgrass & Lespedeza & repens & Trailing bush-clover \\
\hline Ailanthus & altissima & Tree-of-heaven & Lespedeza & violacea & Bush-clover \\
\hline Albizia & julibrissin & Mimosa & Lespedeza & virginica & Slender bush-clover \\
\hline Alisma & subcordatum & Water-plaintain & Leucospora & multifida & - \\
\hline Allium & ampeloprasum & Garlic & Leucothoe & fontanesiana & Dog-hobble \\
\hline Allium & canadense & Wild garlic & Liatris & aspera & Lacerate blazing star \\
\hline Allium & cernuum & Nodding onion & Liatris & spicata & Sessile blazing star \\
\hline Allium & vineale & Field garlic & Ligusticum & canadense & Lovage \\
\hline Alnus & serrulata & Common alder & Ligustrum & sinense & Privet \\
\hline Alopecurus & carolinianus & Carolina-foxtail & Lilium & canadense & Canada lily \\
\hline
\end{tabular}


Table A. (continued)

\begin{tabular}{|c|c|c|c|c|c|}
\hline Genus & Species & Common name & Genus & Species & Common name \\
\hline Amaranthus & hybridus & Amaranth & Linaria & canadensis & Toadflax \\
\hline Ambrosia & artemisiifolia & Ragweed & Linaria & vulgaris & Butter-and-eggs \\
\hline Ambrosia & bidentata & Ragweed & Lindera & benzoin & Spicebush \\
\hline Ambrosia & trifida & Ragweed & Lindernia & dubia & False pimpernell \\
\hline Amelanchier & arborea & Downy juneberry & Linum & medium & Common yellow fax \\
\hline Amelanchier & laevis & Smooth juneberry & Linum & striatum & Ridgestem yellow flax \\
\hline Amianthium & muscaetoxicum & Fly poison & Linum & sulcatum & Grooved yellow flax \\
\hline Ammannia & coccinea & Toothcup & Linum & virginianum & Virginia flax \\
\hline Amorpha & fruticosa & False indigo & Liparis & liliifolia & Lily-leaved twayblade \\
\hline Ampelopsis & cordata & Raccoon-grape & Liparis & loeselii & Fen orchid \\
\hline Amphicarpaea & bracteata & Hog-peanut & Liquidambar & styraciflua & Sweetgum \\
\hline Amsonia & tabernaemontana & Willow amsonia & Liriodendron & tulipifera & Tulliptree \\
\hline Anagallis & arvensis & Pimpernel & Lithospermum & canescens & Orange puccoon \\
\hline Andropogon & gerardii & Big bluestem & Lobelia & cardinalis & Cardinal flower \\
\hline Amaranthus & hybridus & Amaranth & Lobelia & inflata & Indian tobacco \\
\hline Andropogon & ternarius & Silver bluestem & Lobelia & puberula & Downy lobelia \\
\hline Andropogon & virginicus & Virginia broomsedge & Lobelia & siphilitica & Great lobelia \\
\hline Anemone & quinquefolia & Wood anemone & Lobelia & spicata & Lobelia \\
\hline Anemone & virginiana & Thimble weed & Lolium & multiflorum & Italian ryegrass \\
\hline Angelica & venenosa & Hairy angelica & Lolium & perenne & Perennial ryegrass \\
\hline Antennaria & plantaginifolia & Pussy-toes & Lonicera & japonica & Japanese honeysuckle \\
\hline Antennaria & solitaria & Pussy-toes & Lonicera & maackii & - \\
\hline Anthoxanthum & odoratum & Sweet vernal grass & Lotus & corniculatus & Birdfoot trefoil \\
\hline Apios & americana & Ground-nut & Ludwigia & alternifolia & Alternate-leaved seedbox \\
\hline Aplectrum & hyemale & Putty root & Ludwigia & decurrens & Decurrent seedbox \\
\hline Apocynum & cannabinum & Dogbane & Ludwigia & palustris & Water-purslane \\
\hline Aquilegia & canadensis & Columbine & Luzula & acuminata & Wood-rush \\
\hline Arabidopsis & thaliana & Mouse-ear cress & Luzula & bulbosa & Wood-rush \\
\hline Arabis & canadensis & Sicklepod & Luzula & echinata & Wood-rush \\
\hline Arabis & laevigata & Smooth rockcress & Luzula & multiflora & Wood-rush \\
\hline Aralia & racemosa & Spikenard & Lycopodium & obscurum & Treelike clubmoss \\
\hline Aralia & spinosa & Devil's walking stick & Lycopus & americanus & American bugleweed \\
\hline Arctinium & minus & Burdock & Lycopus & virginicus & Virginia water-horehound \\
\hline Arenaria & patula & Sandwort & Lygodium & palmatum & Climbing fern \\
\hline
\end{tabular}


Table A. (continued)

\begin{tabular}{|c|c|c|c|c|c|}
\hline Genus & Species & Common name & Genus & Species & Common name \\
\hline Arenaria & serpyllifolia & Thyme-leaf sandwort & Lyonia & ligustrina & Maleberry \\
\hline Arisaema & dracontium & Green dragon & Lysimachia & ciliata & Fringed loosestrife \\
\hline Arisaema & triphyllum & Jack-in-the-pulpit & Lysimachia & lanceolata & Lance-leaved loosestrife \\
\hline Aristida & dichotoma & Churchmouse three-awn grass & Lysimachia & nummularia & Moneywort \\
\hline Aristida & longespica & Slimspike three-awn grass & Lysimachia & quadrifolia & Smooth loosestrife \\
\hline Aristida & oligantha & Prairie three-awn grass & Lysimachia & tonsa & Appalachian loosestrife \\
\hline Aristida & purpurascens & Purple three-awn grass & Lythrum & alatum & Winged loosestrife \\
\hline Aristolochia & macrophylla & Dutchman's pipe & Lythrum & salicaria & Purple loosestrife \\
\hline Aristolochia & serpentaria & Virginia-snakeroot & Maclura & pomifera & Osage-orange \\
\hline Aronia & arbutifolia & Hairy chokeberry & Magnolia & acuminata & Cucumber-tree \\
\hline Arthraxon & hispidus & - & Magnolia & tripetala & Umbrella magnolia \\
\hline Aruncus & dioicus & Goat's beard & Mahonia & bealei & Oregon grape \\
\hline Arundinaria & gigantea & Cane & Malaxis & unifolia & Adder's mouth \\
\hline Asarum & canadense & Wild ginger & Manfreda & virginica & False aloe \\
\hline Asclepias & amplexicaulis & Blunt-leaved milkweed & Matelea & gonocarpa & Climbing milkweed \\
\hline Asclepias & incarnata & Swamp milkweed & Mecardonia & acuminata & - \\
\hline Asclepias & quadrifolia & - & Medeola & virginiana & Indian cucumber \\
\hline Asclepias & syriaca & Common milkweed & Medicago & lupulina & Black medick \\
\hline Asclepias & tuberosa & Butterfly-weed & Melica & mutica & Melica grass \\
\hline Asclepias & variegata & White milkweed & Melilotus & alba & White sweet-clover \\
\hline Asclepias & verticillata & Whorled milkweed & Melilotus & officinalis & Yellow sweet-clover \\
\hline Asclepias & viridiflora & Milkweed & Menispermum & canadense & Moonseed \\
\hline Asimina & triloba & Paw-paw & Mentha & spicata & Spearmint \\
\hline Asparagus & officinalis & Asparagus & Mentha & x piperita & Peppermint \\
\hline Asplenium & platyneuron & Ebony spleenwort & Microstegium & vimineum & Nepal grass \\
\hline Asplenium & resiliens & Black-stemmed speenwort & Mimulus & alatus & Winged monkey flower \\
\hline Asplenium & rhizophyllum & Walking fern & Mimulus & ringens & Monkey flower \\
\hline Asplenium & ruta-muraria & Wall-rue & Mitchella & repens & Partridgeberry \\
\hline Asplenium & trichomanes & Maidenhair spleenwort & Mitella & diphylla & Bishop's cap \\
\hline Aster & cordifolius & Heart-leaved aster & Mollugo & verticillata & Carpet-weed \\
\hline Aster & divaricatus & White wood aster & Monarda & didyma & Bee-balm \\
\hline Aster & dumosus & Bushy aster & Monarda & fistulosa & Wild bergamot \\
\hline Aster & laevis & Smooth aster & Monotropa & hypopithys & Pine-sap \\
\hline Aster & lateriflorus & Calico aster & Monotropa & uniflora & Indian pipe \\
\hline Aster & novae-anglae & New England aster & Morus & rubra & Red mulberry \\
\hline
\end{tabular}


Table A. (continued)

\begin{tabular}{|c|c|c|c|c|c|}
\hline Genus & Species & Common name & Genus & Species & Common name \\
\hline Aster & oblongifolius & Aromatic aster & Mosla & dianthera & - \\
\hline Aster & ontarionis & Bottomland aster & Muhlenbergia & frondosa & Muhly \\
\hline Aster & patens & Late purple aster & Muhlenbergia & schreberi & Nimblewill \\
\hline Aster & pilosus & Downy aster & Muhlenbergia & sylvatica & Woodland muhly \\
\hline Aster & shortii & Midwestern heart-leaved aster & Muhlenbergia & tenuiflora & Muhly \\
\hline Aster & surculosos & Recurved aster & Murdannia & keisak & - \\
\hline Aster & undulatus & Clasping heart-leaved aster & Myosotis & macrosperma & Large-seeded forget-me-not \\
\hline Aster & urophyllus & Arrow-leaved aster & Myosotis & verna & Early forget-me-not \\
\hline Astilbe & biternata & False goat's beard & Myosurus & minimus & Mouse-tail \\
\hline Astragalus & canadensis & Milkvetch & Myriophyllum & spicatum & European water-milfoil \\
\hline Athyrium & filix-femina & Lady fern & Najas & guadalupensis & Southern water-nymph \\
\hline Aureolaria & laevigata & Smooth false-foxglove & Nasturtium & officinale & Watercress \\
\hline Aureolaria & patula & Spreading false-foxglove & Nicandra & physalodes & Apple-of-Peru \\
\hline Aureolaria & virginica & Downy false-foxglove & Nyssa & sylvatica & Black gum \\
\hline Barbarea & verna & Early winter-cress & Obolaria & virginica & Pennywort \\
\hline Barbarea & vulgaris & Yellow rocket & Oenothera & biennis & Evening primrose \\
\hline Bartonia & paniculata & Screwstem & Oenothera & fruticosa & Sundrops \\
\hline Belamcanda & chinensis & Blackberry lily & Oenothera & laciniata & Cut-leaved primrose \\
\hline Betula & nigra & River birch & Onoclea & sensibilis & Sensitive fern \\
\hline Bidens & cernua & Stick-tights & Ophioglossum & engelmannii & Limestone adder's tongue fern \\
\hline Bidens & frondosa & Beggar-ticks & Ophioglossum & pycnostichium & Southeastern adder's tongue fern \\
\hline Bidens & polylepis & Ozark tickseed & Opuntia & humifusa & Prickly pear cactus \\
\hline Bidens & tripartita & Stick-tight & Orbexilum & onobrychis & Tall psoralea \\
\hline Bidens & bipinnata & Spanish-needles & Orbexilum & pedunculatum & Sampson's snakeroot \\
\hline Bignonia & capreolata & Cross-vine & Ornithogalum & umbellatum & Star of Bethlehem \\
\hline Blephilia & ciliata & Woodmint & Orobanche & uniflora & One-flowered cancer-root \\
\hline Boehmeria & cylindrica & False-nettle & Orontium & aquaticum & Golden club \\
\hline Botrychium & biternatum & Sparse-lobed grape fern & Osmorhiza & claytonii & Bland sweet cicely \\
\hline Botrychium & dissectum & Common grape fern & Osmorhiza & longistylis & Long styled sweet cicely \\
\hline Botrychium & virginianum & Rattlesnake fern & Osmunda & cinnamomea & Cinnamon fern \\
\hline Bouteloua & curtipendula & Side-oats gramma grass & Osmunda & regalis & Royal fern \\
\hline Brachyeletrum & erectum & - & Ostrya & virginiana & Hop-hornbeam \\
\hline Brassica & rapa & Rape mustard & Oxalis & grandis & Large wood sorrel \\
\hline Bromus & altiissimus & - & Oxalis & stricta & Wood sorrel \\
\hline Bromus & commutatus & Common brome grass & Oxalis & violacea & Wood sorrel \\
\hline
\end{tabular}


Table A. (continued)

\begin{tabular}{|c|c|c|c|c|c|}
\hline Genus & Species & Common name & Genus & Species & Common name \\
\hline Bromus & hordeaceus & Soft chess & Oxydendrum & arboreum & Sourwood \\
\hline Bromus & japonicus & Japanese chess & Oxypolis & rigidior & Cowbane \\
\hline Bromus & pubescens & - & Pachysandra & procumbens & Allegheny-spurge \\
\hline Bromus & tectorum & Brome grass & Panax & quinquefolius & Ginseng \\
\hline Buglossoides & arvense & - & Panicum & acuminatum & Panic grass \\
\hline Bulbostylis & capillaris & Sedge & Panicum & acuminatum & Panic grass \\
\hline Bumelia & lycioides & Smooth southern buckthorn & Panicum & anceps & Panic grass \\
\hline Cacalia & atriplicifolia & Pale Indian-plantain & Panicum & angustifolium & Panic grass \\
\hline Calamintha & nepeta & Basil-thyme & Panicum & boscii & Panic grass \\
\hline Callitriche & heterophylla & Water star-wort & Panicum & capillare & Panic grass \\
\hline Calycanthus & floridus & Sweetshrub & Panicum & clandestinium & Panic grass \\
\hline Calystegia & sepium & Hedge bindweed & Panicum & commutatum & Panic grass \\
\hline Calystegia & spithamaea & Low bindweed & Panicum & depauperatum & Panic grass \\
\hline Campanula & americana & Tall bellwort & Panicum & dichotomiflorum & Panic grass \\
\hline Campanula & divaricata & Southern harebell & Panicum & dichotomum & Panic grass \\
\hline Campsis & radicans & Trumpet-creper & Panicum & flexile & Panic grass \\
\hline Capsella & bursa-pastoris & Sheperd's purse & Panicum & laxiflorum & Panic grass \\
\hline Cardamine & douglassii & Pink spring-cress & Panicum & microcarpon & Panic grass \\
\hline Cardamine & hirsuta & Hairy bittercress & Panicum & ovale & Panic grass \\
\hline Cardamine & parviflora & - & Panicum & polyanthes & Panic grass \\
\hline Cardamine & pensylvanica & Pennsylvania bittercresss & Panicum & rigidulum & Panic grass \\
\hline Cardamine & rhombiodea & Spring-cress & Panicum & scoparium & Panic grass \\
\hline Carex & abscondita & Thicket sedge & Panicum & sphaerocarpon & Panic grass \\
\hline Carex & albicans & Sedge & Panicum & virgatum & Panic grass \\
\hline Carex & albicans & Sedge & Paronychia & fastigiata & Forked chickweed \\
\hline Carex & albolutescens & Light-colored sedge & Parthenium & integrifolium & Wild quinine \\
\hline Carex & albursina & Sedge & Parthenocissus & quinquefolia & Virginia creeper \\
\hline Carex & amphibola & Sedge & Paspalum & boscianum & - \\
\hline Carex & atlantica & Sedge & Paspalum & dilatatum & - \\
\hline Carex & atlantica & Howe's sedge & Paspalum & laeve & - \\
\hline Carex & baileyi & Bailey's sedge & Paspalum & pubiflorum & - \\
\hline Carex & blanda & Sedge & Paspalum & setaceum & - \\
\hline Carex & bromoides & Sedge & Paspalum & setaceum & - \\
\hline Carex & caroliniana & Carolina sedge & Passiflora & incarnata & Purple passion flower \\
\hline Carex & cephalophora & Sedge & Passiflora & lutea & Yellow passion flower \\
\hline
\end{tabular}


Table A. (continued)

\begin{tabular}{|c|c|c|c|c|c|}
\hline Genus & Species & Common name & Genus & Species & Common name \\
\hline Carex & cherokeensis & Cherokee sedge & Paulownia & tomentosa & Princess-tree \\
\hline Carex & complanata & Sedge & Pellaea & atropurpurea & Purple-stemmed cliffbrake \\
\hline Carex & conjuncta & Sedge & Pellaea & glabella & Smooth cliffbrake \\
\hline Carex & crinita & Drooping sedge & Penstemon & canescens & Hairy beard-tongue \\
\hline Carex & crus-corvi & Sedge & Penstemon & digitalis & Large-flowered beard-tongue \\
\hline Carex & debilis & Necklace sedge & Penstemon & laevigatus & Smooth beard-tongue \\
\hline Carex & digitalis & Sedge & Penstemon & pallidus & Eastern white beard-tongue \\
\hline Carex & eburnea & Black-fruited sedge & Penthorum & sedoides & Ditch stone-crop \\
\hline Carex & festucacea & Sedge & Perilla & frutescens & Beefsteak plant \\
\hline Carex & frankii & Frank's sedge & Phacelia & bipinnatifida & Purple phacelia \\
\hline Carex & granularis & Granular sedge & Phacelia & purshii & Pursh's purple phacelia \\
\hline Carex & gravida & Heavy sedge & Phalaris & arundinacea & Reed canary grass \\
\hline Carex & grayi & Gray's sedge & Phaseolus & polystachyus & Wild bean \\
\hline Carex & grisea & Sedge & Philadelphus & hirsutus & Hairy mock-orange \\
\hline Carex & intumescens & Intumescent sedge & Philadelphus & inodorus & Mock-orange \\
\hline Carex & jamesii & Sedge & Phleum & pratense & Common timothy \\
\hline Carex & laxiflora & Broad-leaved sedge & Phlox & amoena & Hairy phlox \\
\hline Carex & leptalea & Sedge & Phlox & amplifolia & Wide-leaved phlox \\
\hline Carex & louisianica & Louisiana sedge & Phlox & divaricata & Forest phlox \\
\hline Carex & lupulina & Large hop sedge & Phlox & glaberrima & Smooth phlox \\
\hline Carex & lurida & Smaller hop sedge & Phlox & maculata & Meadow phlox \\
\hline Carex & meadii & Sedge & Phlox & paniculata & Summer phlox \\
\hline Carex & muhlenbergii & Sedge & Phlox & stolonifera & Crawling phlox \\
\hline Carex & nigromarginata & Black-margined sedge & Phoradendron & leucarpum & Mistletoe \\
\hline Carex & normalis & Sedge & Phryma & leptostachya & Lopseed \\
\hline Carex & oligocarpa & Sedge & Phyla & lanceolata & Fog-fruit \\
\hline Carex & oxylepis & Sedge & Phyllanthus & caroliniensis & Phyllanthus \\
\hline Carex & oxylepis & Sedge & Physalis & longifolia & Downy ground-cherry \\
\hline Carex & pensylvanica & Sedge & Physalis & pubescens & Hairy ground-cherry \\
\hline Carex & platyphylla & Sedge & Physalis & virginiana & Virginia ground-cherry \\
\hline Carex & prasina & Drooping sedge & Physostegia & virginiana & False dragonhead \\
\hline Carex & projecta & Sedge & Phytolacca & americana & Pokeweed \\
\hline Carex & purpurifera & Sedge & Pilea & pumila & Clearweed \\
\hline Carex & retroflexa & Sedge & Pinus & echinata & Short-leaf pine \\
\hline Carex & rosea & Sedge & Pinus & strobus & White pine \\
\hline
\end{tabular}


Table A. (continued)

\begin{tabular}{|c|c|c|c|c|c|}
\hline Genus & Species & Common name & Genus & Species & Common name \\
\hline Carex & scoparia & Sedge & Pinus & taeda & Loblloly pine \\
\hline Carex & shortiana & Sedge & Pinus & virginiana & Scrub pine \\
\hline Carex & squarrosa & Round-headed sedge & Plantago & aristata & Plantain \\
\hline Carex & stipata & Stipatate sedge & Plantago & lanceolata & Plantain \\
\hline Carex & striatula & Sedge & Plantago & pusilla & Small plantain \\
\hline Carex & styloflexa & Sedge & Plantago & rugelii & Plantain \\
\hline Carex & swanii & Swan's sedge & Plantago & virginica & Plantain \\
\hline Carex & tribuloides & Sedge & Platanthera & clavellata & Green woodland orchid \\
\hline Carex & venusta & Sedge & Platanthera & flava & Northern tubercled orchid \\
\hline Carex & virescens & Sedge & Platanthera & lacera & Green-fringed orchid \\
\hline Carex & vulpinoidea & Fox sedge & Platanthera & peramoena & Purple-fringeless orchid \\
\hline Carex & willdenowii & Sedge & Platanus & occidentalis & Sycamore \\
\hline Carpinus & caroliniana & Iron wood & Pluchea & camphorata & Camphorweed \\
\hline Carya & cordiformis & Bitternut hickory & Poa & alsodes & - \\
\hline Carya & glabra & Pignut hickory & Poa & annua & Annual bluegrass \\
\hline Carya & ovalis & Sweet pignut hickory & Poa & autumnalis & Autumn bluegrass \\
\hline Carya & ovata & Shagbark hickory & Poa & compressa & Bluegrass \\
\hline Carya & tomentosa & Mockernut hickory & Poa & cuspidata & Woodland bluegrass \\
\hline Castanea & dentata & American chestnut & Poa & pratensis & Junegrass \\
\hline Catalpa & bignonioides & Catalpa & Poa & sylvestris & Woodland bluegrass \\
\hline Caulophyllum & thalictroides & Blue cohosh & Podophyllum & peltatum & May-apple \\
\hline Ceanothus & americanus & New Jersey tea & Polemonium & reptans & Spreading Jacob's ladder \\
\hline Celastrus & orbiculatus & Oriental bittersweet & Polygala & curtissii & Curtiss' milkwort \\
\hline Celastrus & scandens & Climbing bittersweet & Polygala & incarnata & Pink milkwort \\
\hline Celtis & laevigata & Smooth hackberry & Polygala & sanguinea & Blood-milkwort \\
\hline Celtis & occidentalis & Common hackberry & Polygala & senega & Seneca-snakeroot \\
\hline Centaurea & cyanus & Bachelor's button & Polygala & verticillata & Loose milkwort \\
\hline Centaurea & maculosa & Bachelor's button & Polygala & verticillata & Whorled milkwort \\
\hline Centrosema & virginianum & Butterfly-pea & Polygonatum & biflorum & Smooth Solomon's seal \\
\hline Cephalanthus & occidentalis & Buttonbush & Polygonum & caespitosum & Smartweed \\
\hline Cerastium & fontanum & Mouse-ear chickweed & Polygonum & cuspidatum & Japanese knotweed \\
\hline Cerastium & glomeratum & Mouse-ear chickweed & Polygonum & hydropiper & Water-pepper \\
\hline Ceratophyllum & demersum & Hornwort & Polygonum & hydropiperoides & Water smartweed \\
\hline Cercis & canadensis & Redbud & Polygonum & lapathifolium & Smartweed \\
\hline Chaennorrhinum & minus & Lesser toadflax & Polygonum & pensylvanicum & Smartweed \\
\hline
\end{tabular}


Table A. (continued)

\begin{tabular}{|c|c|c|c|c|c|}
\hline Genus & Species & Common name & Genus & Species & Common name \\
\hline Chaerophyllum & procumbens & Spreading chervil & Polygonum & persicaria & Smartweed \\
\hline Chaerophyllum & tainturieri & Wild cervil & Polygonum & punctatum & Smartweed \\
\hline Chamaecrista & fasciculata & Partridge-pea & Polygonum & sagittatum & Teartumb \\
\hline Chamaecrista & nictitans & Sensitive-pea & Polygonum & scandens & Climbing buckwheat \\
\hline Chamaelirium & luteum & Fairy wand & Polygonum & virginianum & Virginia knotweed \\
\hline Chasmanthium & latifolium & Spangle grass & Polymnia & canadensis & Leaf-cup \\
\hline Chasmanthium & laxum & Slender spike grass & Polymnia & uvedalia & Bear's foot \\
\hline Chasmanthium & sessiliflorum & Long-leaf spike grass & Polypodium & polypodioides & Resurrection fern \\
\hline Cheilanthes & alabamensis & Alabama lipfern & Polypodium & virginianum & Rock polypody fern \\
\hline Cheilanthes & lanosa & Hairy lipfern & Polypremum & procumbens & - \\
\hline Chelone & glabra & White turtlehead & Polystichum & acrostichoides & Christmas fern \\
\hline Chenopodium & album & White goosefoot & Poncircus & trifoliata & Trifoliate orange \\
\hline Chenopodium & ambrosioides & Fragrant goosefoot & Populus & alba & Silvery poplar \\
\hline Chimaphila & maculata & Striped pipsissewa & Populus & deltoides & Eastern cottonwood \\
\hline Chionanthus & virginicus & Fringe-tree & Populus & x jackii & - \\
\hline Chrysanthemum & leucanthemum & Daisy & Porteranthus & trifoliatus & Bowman's root \\
\hline Cichorium & intybus & Chicory & Potamogeton & crispus & Pondweed \\
\hline Cicuta & maculata & Water-hemlock & Potamogeton & diversifolius & Pondweed \\
\hline Cimicifuga & racemosa & Black cohosh & Potamogeton & foliosus & Pondweed \\
\hline Cimicifuga & rubifolia & Appalachian bugbane & Potamogeton & pusillus & Pondweed \\
\hline Cinna & arundinacea & Reedgrass & Potentilla & canadensis & Dwarf cinquefoil \\
\hline Circaea & lutetiana & Larger enchanter's-nightshade & Potentilla & norvegica & Rough cinquefoil \\
\hline Cirsium & arvense & Canada thistle & Potentilla & recta & Rough-fruited cinquefoil \\
\hline Cirsium & discolor & Thistle & Prenanthes & serpentaria & Rattlesnakeroot \\
\hline Cirsium & muticum & Swamp thistle & Prenanthes & trifoliolata & Lion's foot \\
\hline Cirsium & vulgare & Bull thistle & Prunella & vulgaris & Heal-all \\
\hline Claytonia & caroliniana & Broad-leaved spring beauty & Prunus & americana & Wild plum \\
\hline Claytonia & virginica & Narrow-leaved spring beauty & Prunus & munsoniana & Munson plum \\
\hline Clematis & viorna & Leather flower & Prunus & serotina & Black cherry \\
\hline Clematis & virginiana & Virgin's bower & Ptelea & trifoliata & Wafer ash \\
\hline Clitoria & mariana & Butterfly-pea & Pteridium & aquilinum & Bracken fern \\
\hline Cocculus & carolinus & Snailseed & Pueraria & lobata & Kudzu \\
\hline Collinsonia & canadensis & Stoneroot & Pycnanthemum & incanum & Hoary mountain-mint \\
\hline Collinsonia & verticillata & Whorled stoneroot & Pycnanthemum & incanum & Hoary mountain-mint \\
\hline Commandra & umbellata & Bastard toad-flax & Pycnanthemum & pilosum & Mountain-mint \\
\hline
\end{tabular}


Table A. (continued)

\begin{tabular}{|c|c|c|c|c|c|}
\hline Genus & Species & Common name & Genus & Species & Common name \\
\hline Commelina & communis & Common dayflower & Pycnanthemum & tenuifolium & Narrow-leaved mountain-mint \\
\hline Commelina & erecta & Erect dayflower & Pycnanthemum & virginianum & Mountain-mint \\
\hline Commelina & virginica & Virginia dayflower & Pyrrhopappus & carolinianus & False dandelion \\
\hline Conoclinium & coelestinum & Mist flower & Pyrularia & pubera & Buffalo-nut \\
\hline Conopholis & americana & Squawroot & Quercus & alba & White oak \\
\hline Consolida & ambigua & Rocket larkspur & Quercus & bicolor & Swamp white oak \\
\hline Convallaria & majalis & Lily-of-the-valley & Quercus & coccinea & Scarlet oak \\
\hline Conyza & canadensis & Horseweed & Quercus & falcata & Southern red oak \\
\hline Corallorrhiza & odontorhiza & Autumn coralroot & Quercus & marilandica & Blackjack oak \\
\hline Corallorrhiza & wisteriana & Spring coralroot & Quercus & michauxii & Swamp chestnut oak \\
\hline Coreopsis & auriculata & Lobed tickseed & Quercus & montana & Chestnut oak \\
\hline Coreopsis & major & Wood tickseed & Quercus & muehlenbergii & Chinkapin oak \\
\hline Coreopsis & tinctoria & Plains tickseed & Quercus & palustris & Pin oak \\
\hline Coreopsis & tripteris & Tall tickseed & Quercus & rubra & Northern red oak \\
\hline Cornus & amomum & Silky dogwood & Quercus & shumardii & Shumard oak \\
\hline Cornus & drummondii & Rough-leaved dogwood & Quercus & stellata & Post oak \\
\hline Cornus & florida & Flowering dogwood & Quercus & velutina & Black oak \\
\hline Cornus & foemina & Southern swamp dogwood & Ranunculus & abortivus & Small-flowered crowfoot \\
\hline Coronilla & varia & Crown-vetch & Ranunculus & acris & Common buttercup \\
\hline Corydalis & flavula & Short-spurred corydalis & Ranunculus & bulbosus & Bulbous buttercup \\
\hline Corylus & americana & American hazelnut & Ranunculus & carolinianus & Carolina buttercup \\
\hline Crataegus & calpodenron & Hawthorn & Ranunculus & fascicularis & Thick-root buttercup \\
\hline Crataegus & crus-galli & Hawthorn & Ranunculus & hispidus & Hispid buttercup \\
\hline Crepis & pulchra & Hawk's beard & Ranunculus & parviflorus & Small-flowered buttercup \\
\hline Crotalaria & sagittalis & Weedy rattlebox & Ranunculus & pusilus & - \\
\hline Croton & glandulosus & Tooth-leaved croton & Ranunculus & recurvatus & Hooked buttercup \\
\hline Croton & monanthogynus & - & Ranunculus & repens & Creeping buttercup \\
\hline Cryptotaenia & canadensis & Honewort & Ranunculus & sardos & - \\
\hline Cunila & origanoides & Dittany & Ranunculus & sceleratus & Cursed crowfoot \\
\hline Cuphea & viscosissima & Clammy cuphea & Ratibida & pinnata & Gray coneflower \\
\hline Cuscuta & campestris & Field dodder & Rhamnus & caroliniana & Carolina buckthorn \\
\hline Cuscuta & compacta & Bracted dodder & Rhexia & mariana & Pale meadow beauty \\
\hline Cuscuta & gronovii & Dodder & Rhexia & virginica & Meadow beauty \\
\hline Cynanchum & laeve & Sandvine & Rhododendron & maximum & Rosebay rhododendron \\
\hline Cynodon & dactylon & Bermuda grass & Rhododendron & minus & Small-leaved rhododendron \\
\hline
\end{tabular}


Table A. (continued)

\begin{tabular}{|c|c|c|c|c|c|}
\hline Genus & Species & Common name & Genus & Species & Common name \\
\hline Cynoglossum & virginianum & Wild comfrey & Rhododendron & periclymenoides & Pinxter-bush \\
\hline Cyperus & acuminatus & Umbrella sedge & Rhus & aromatica & Fragrant sumac \\
\hline Cyperus & croceus & Umbrella sedge & Rhus & copallina & Winged sumac \\
\hline Cyperus & echinatus & Umbrella sedge & Rhus & glabra & Smooth sumac \\
\hline Cyperus & esculentus & Chufa & Rhynchosia & tomentosa & Hairy rhynchosia \\
\hline Cyperus & ferruginescens & Umbrella sedge & Rhynchospora & capitellata & Beak-rush \\
\hline Cyperus & flavescens & Umbrella sedge & Rhynchospora & colorata & White-top sedge \\
\hline Cyperus & lancastriensis & Umbrella sedge & Rhynchospora & globularis & Beak-rush \\
\hline Cyperus & odoratus & Umbrella sedge & Robinia & hispida & Bristly locust \\
\hline Cyperus & pseudovegetus & Umbrella sedge & Robinia & pseudoacacia & Black locust \\
\hline Cyperus & retrofractus & Umbrella sedge & Rorippa & palustris & Common yellow-cress \\
\hline Cyperus & strigosus & Umbrella sedge & Rorippa & sessiliflora & Southern yellow-cress \\
\hline Cypripedium & acaule & Pink lady's slipper & Rosa & carolina & Carolina rose \\
\hline Cystopteris & bulbifera & Bulbet fern & Rosa & multiflora & Multiflora rose \\
\hline Cystopteris & protrusa & Southern fragile fern & Rosa & setigera & Prairie rose \\
\hline Dactylis & glomerata & Orchard grass & Rotala & ramosior & Toothcup \\
\hline Danthonia & spicata & Poverty grass & Rubus & argutus & Highbush blackberry \\
\hline Dasystoma & macrophylla & Mullein-foxglove & Rubus & flagellaris & Northern dewberry \\
\hline Datura & stramonium & Jimson weed & Rubus & phoenicolasius & Wineberry \\
\hline Daucus & carota & Queen Anne's lace & Rudbeckia & fulgida & Eastern coneflower \\
\hline Delphinium & exaltatum & Tall larkspur & Rudbeckia & hirta & Black-eyed Susan \\
\hline Delphinium & tricorne & Dwarf larkspur & Rudbeckia & laciniata & Golden glow \\
\hline Dennstaedtia & punctilobula & Hay-scented fern & Rudbeckia & triloba & Three-lobed coneflower \\
\hline Dentaria & diphylla & Toothwort & Ruellia & caroliniensis & Carolina ruellia \\
\hline Dentaria & heterophylla & Pepperwort & Ruellia & purshiana & Pursh's wild petunia \\
\hline Dentaria & laciniata & Cut-leaved toothwort & Ruellia & strepens & Ruellia \\
\hline Dentaria & multifida & Fine-leaved toothwort & Rumex & acetosella & Shep sorrel \\
\hline Deparia & acrostichoides & Silvery glade fern & Rumex & conglomeratus & Dock \\
\hline Desmanthus & illinoesis & Bundleflower & Rumex & crispus & Curled dock \\
\hline Desmodium & canescens & Tick-trefoil & Rumex & obtusifolius & Bitter dock \\
\hline Desmodium & ciliare & Tick-trefoil & Sabatia & angularis & Rose-pink \\
\hline Desmodium & cuspidatum & Tick-trefoil & Sagittaria & australis & Appalachian arrow-head \\
\hline Desmodium & glutinosum & Whorled tick-trefoil & Sagittaria & calycina & Mississippi arrow-head \\
\hline Desmodium & marilandicum & Narrow tick-trefoil & Sagittaria & latifolia & Broad-leaved arrow-head \\
\hline Desmodium & nudiflorum & Naked-flowered tick-trefoil & Salix & alba & White willow \\
\hline
\end{tabular}


Table A. (continued)

\begin{tabular}{|c|c|c|c|c|c|}
\hline Genus & Species & Common name & Genus & Species & Common name \\
\hline Desmodium & nuttallii & Nuttall's tick-trefoil & Salix & babylonica & Weeping willow \\
\hline Desmodium & paniculatum & Panicled tick-trefoil & Salix & caroliniana & Carolinia willow \\
\hline Desmodium & pauciflorum & Few-flowered tick-trefoil & Salix & exigua & Sandbar willow \\
\hline Desmodium & rotundifolium & Prostrate tick-trefoil & Salix & humilis & Prairie willow \\
\hline Desmodium & viridiflorum & Tick-trefoil & Salix & nigra & Black willow \\
\hline Dianthus & armeria & Deptford pink & Salvia & lyrata & Lyre-leaved mint \\
\hline Diervilla & lonicera & Bush honeysuckle & Salvia & urticifolia & Nettle-leaved sage \\
\hline Digitaria & filiformis & Crabgrass & Sambucus & canadensis & American elder \\
\hline Digitaria & ischaemum & Smooth crabgrass & Samolus & parviflorus & Water-pimpernel \\
\hline Digitaria & sanguinalis & Crabgrass & Sanguinaria & canadensis & Bloodroot \\
\hline Diodia & teres & Rough buttonweed & Sanicula & canadensis & Canada snakeroot \\
\hline Diodia & virginiana & Virginia buttonweed & Sanicula & odorata & Black snakeroot \\
\hline Dioscorea & batatas & Chinese yam & Sanicula & smallii & Southern snakeroot \\
\hline Dioscorea & villosa & Wild yam & Saponaria & officinalis & Soapwort \\
\hline Diospyros & virginiana & Persimmon & Sassafras & albidum & Sassafras \\
\hline Diphasiastrum & digitatum & Ground cedar & Satureja & vulgaris & Basil \\
\hline Diplazium & pycnocarpon & Glade fern & Salix & babylonica & Weeping willow \\
\hline Dipsacus & fullonum & Teasel & Saururus & cernuus & Lizard's tail \\
\hline Dirca & plaustris & Leatherwood & Saxifraga & careyana & Carey's saxifrage \\
\hline Disporum & lanuginosum & Mandarin lily & Schizachyrium & scoparium & Little bluestem \\
\hline Dodecatheon & meadia & Shooting star & Schrankia & microphylla & Sensitive-brier \\
\hline Doellingeria & infirmus & Entire-leaved aster & Scirpus & americanus & Threesquare bulrush \\
\hline Draba & brachycarpa & Short-fruited whitlow-grass & Scirpus & atrovirens & Black bulrush \\
\hline Draba & ramosissima & Branched whitlow grass & Scirpus & cyperinus & Wool-grass \\
\hline Draba & verna & Whitlow grass & Scirpus & fluviatilis & River bulrush \\
\hline Dryopteris & intermedia & Fancy woodfern & Scirpus & pendulus & Bulrush \\
\hline Dryopteris & marginalis & Marginal woodfern & Scirpus & polyphyllus & Many-leaved bulrush \\
\hline Duchesnea & indica & Barren strawberry & Scirpus & purshianus & Bluntscale bulrush \\
\hline Echinacea & purpurea & Purple coneflower & Scirpus & tabernaemontanii & Great bulrush \\
\hline Echinochloa & crusgalli & Barnyard grass & Scleria & oligantha & Nut-rush \\
\hline Echinochloa & muricata & Barnyard grass & Scleria & pauciflora & Nut-rush \\
\hline Eclipta & prostrata & Yerba-de-tajo & Scleria & triglomerata & Nut-rush \\
\hline Elaeagnus & pungens & Oleaster & Scrophularia & marilandica & Figwort \\
\hline Elaeagnus & umbellata & Oleaster & Scutellaria & elliptica & Hairy skullcap \\
\hline Eleocharis & acicularis & Spike-rush & Scutellaria & incana & Downy skullcap \\
\hline
\end{tabular}


Table A. (continued)

\begin{tabular}{|c|c|c|c|c|c|}
\hline Genus & Species & Common name & Genus & Species & Common name \\
\hline Eleocharis & erythropoda & Spike-rush & Scutellaria & integrifolia & Entire-leaved skullcap \\
\hline Eleocharis & obtusa & Spike-rush & Scutellaria & lateriflora & Maddog skullcap \\
\hline Eleocharis & palustris & Spike-rush & Scutellaria & leonardii & Skullcap \\
\hline Eleocharis & parvula & Spike-rush & Scutellaria & nervosa & Skullcap \\
\hline Eleocharis & quadrangulata & Spike-rush & Scutellaria & elliptica & Hairy skullcap \\
\hline Eleocharis & tenuis & Spike-rush & Scutellaria & pseudoserrata & Skullcap \\
\hline Elephantopus & carolinianus & Elephant's foot & Sedum & pulchellum & Widow's cross \\
\hline Elephantopus & tomentosus & Elephant's foot & Sedum & ternatum & Wild stonecrop \\
\hline Eleusine & indica & Goosegrass & Selaginella & apoda & Meadow spikemoss \\
\hline Elodea & canadensis & Common water-weed & Senecio & anonymus & Yellow ragwort \\
\hline Elodea & nuttallii & Free-flowered water-weed & Senecio & aureus & - \\
\hline Elymus & hystrix & Bottlebrush-grass & Senecio & obovatus & Golden ragwort \\
\hline Elymus & villosus & Downy wild rye & Senna & marilandica & Wild senna \\
\hline Elymus & virginicus & Wild rye & Senna & obtusifolia & Sickle-pod \\
\hline Elymus & virginicus & Wild rye & Sericocarpus & asteriodes & White-topped aster \\
\hline Epifagus & virginiana & Beech drops & Sericocarpus & linifolius & - \\
\hline Epigaea & repens & Trailing arbutus & Setaria & faberi & Foxtail \\
\hline Epilobium & coloratum & Willow-herb & Setaria & parviflora & Foxtail \\
\hline Equisetum & arvense & Field horsetail & Setaria & pumila & Foxtail \\
\hline Equisetum & hyemale & Scouring rush & Setaria & viridis & Green foxtail \\
\hline Eragrostis & cilianensis & Lovegrass & Sherardia & arvensis & Field-madder \\
\hline Eragrostis & curvula & South African lovegrass & Sibara & virginica & Sibara \\
\hline Eragrostis & frankii & - & Sida & spinosa & Prickly mallow \\
\hline Eragrostis & hypnoides & Creeping lovegrass & Silene & antirrhina & Sleepy catchfly \\
\hline Eragrostis & pectinacea & Carolina lovegrass & Silene & stellata & Starry campion \\
\hline Eragrostis & spectabilis & Tumblegrass & Silene & virginica & Fire pink \\
\hline Erechtites & hieracifolia & Pilewort & Silphium & asteriscus & Rosin-weed \\
\hline Erianthus & alopecuroides & Beardgrass & Silphium & compositum & Lesser basal-leaved rosin-weed \\
\hline Erianthus & giganteus & Tall beardgrass & Silphium & terebinthinaceum & Prairie dock \\
\hline Erigenia & bulbosa & Salt-and-pepper & Silphium & trifoliatum & Whorled rosin-weed \\
\hline Erigeron & annuus & Annual fleabane & Sisyrinchium & albidum & Blue-eyed grass \\
\hline Erigeron & philadelphicus & Fleabane & Sisyrinchium & angustifolium & Blue-eyed grass \\
\hline Erigeron & pulchellus & Robin's plantain & Sisyrinchium & atlanticum & Blue-eyed grass \\
\hline Erigeron & strigosus & Fleabane & Sisyrinchium & mucronatum & Blue-eyed grass \\
\hline Erysimum & cheiranthoides & Worm-seed mustard & Smilacina & racemosa & False Solomon's seal \\
\hline
\end{tabular}


Table A. (continued)

\begin{tabular}{|c|c|c|c|c|c|}
\hline Genus & Species & Common name & Genus & Species & Common name \\
\hline Erythronium & americanum & Trout-lily & Smilax & bona-nox & Catbrier \\
\hline Erythronium & umbilicatum & Trout-lily & Smilax & ecirrata & Carrion flower \\
\hline Euonymus & americanus & Heart's-a-bursting & Smilax & glauca & Glaucous catbrier \\
\hline Euonymus & atropurpureus & Wahoo & Smilax & pulverulenta & Vining carrion flower \\
\hline Eupatorium & album & White eupatorium & Smilax & rotundifolia & Greenbrier \\
\hline Eupatorium & altissimum & Tall eupatorium & Smilax & taminoides & Bristly greenbrier \\
\hline Eupatorium & capillifolium & Dog-fennel & Solanum & carolinense & Horse-nettle \\
\hline Eupatorium & fistulosum & Joe-Pye-weed & Solanum & ptycanthum & Nightshade \\
\hline Eupatorium & hyssopifolium & Narrow-leaved snakeroot & Solidago & arguta & - \\
\hline Eupatorium & perfoliatum & Boneset & Solidago & caesia & - \\
\hline Eupatorium & pilosum & Ragged eupatorium & Solidago & canadensis & Goldenrod \\
\hline Eupatorium & purpureum & Woodland Joe-Pye-weed & Solidago & erecta & Erect goldenrod \\
\hline Eupatorium & rotundifolium & Round-leaved snakeroot & Solidago & flexicaulis & Zig-zag goldenrod \\
\hline Eupatorium & serotinum & Acuminate-leaved snakeroot & Solidago & gigantea & Tall goldenrod \\
\hline Eupatorium & sessilifolium & Upland boneset & Solidago & nemoralis & Southern gray goldenrod \\
\hline Euphorbia & corollata & Flowering spurge & Smilax & bona-nox & Catbrier \\
\hline Euphorbia & dentata & Toothed spurge & Solidago & odora & Fragrant goldenrod \\
\hline Euphorbia & heterophylla & Fire-on-the-mountain & Solidago & patula & Rough-leaved goldenrod \\
\hline Euphorbia & humistrata & Spurge & Solidago & rigida & Stiff goldenrod \\
\hline Euphorbia & maculata & Nodding spurge & Solidago & rugosa & Wrinkled-leaved goldenrod \\
\hline Euphorbia & mercurialina & Cumberland spurge & Solidago & speciosa & Showy goldenrod \\
\hline Euphorbia & nutans & Eyebane & Solidago & sphacelata & Short pappus goldenrod \\
\hline Euthamia & graminifolia & Common flat-topped goldenrod & Solidago & ulmifolia & Elm-leaved goldenrod \\
\hline Fagus & grandifolia & American beech & Sonchus & asper & Prickly sow-thistle \\
\hline Festuca & arundinacea & Meadow fescue & Sorghastrum & nutans & Indian grass \\
\hline Festuca & pratensis & Fescue & Sorghum & halepense & Johnson grass \\
\hline Festuca & rubra & Red fescue & Sparganium & americanum & Bur-reed \\
\hline Festuca & subverticillata & Woodland fescue & Sphenopholis & nitida & Shining sphenopholis \\
\hline Fimbristylis & autumnalis & - & Sphenopholis & obtusata & Blunt sphenopholis \\
\hline Fleishmannia & incarnata & Pink eupatorium & Spigelia & marilandica & Indian pink \\
\hline Fothergilla & major & Witch-alder & Spiraea & tomentosa & Hardhack \\
\hline Fragaria & virginiana & Wild strawberry & Spiranthes & cernua & Nodding lady's tresses \\
\hline Fraxinus & americana & White ash & Spiranthes & lacera & Slender lady's tresses \\
\hline Fraxinus & pennsylvanica & Green ash & Spiranthes & lucida & Shining lady's tresses \\
\hline Fraxinus & quadrangulata & Blue ash & Spiranthes & ovalis & Lesser lady's tresses \\
\hline
\end{tabular}


Table A. (continued)

\begin{tabular}{|c|c|c|c|c|c|}
\hline Genus & Species & Common name & Genus & Species & Common name \\
\hline Galactia & volubilis & Milk pea & Spiranthes & tuberosa & Little lady's tresses \\
\hline Galax & urceolata & Galax & Spiranthes & vernalis & Early lady's tresses \\
\hline Galearis & spectabilis & Showy orchis & spirodela & polyrhiza & Duckweed \\
\hline Galium & aparine & Cleavers & spirodela & punctata & Duckweed \\
\hline Galium & circaezans & Wild licorice & Sporobolus & clandestinus & Rough dropseed \\
\hline Galium & obtusum & Blunt-leaved bedstraw & Sporobolus & indicus & Smutgrass \\
\hline Galium & parisiense & - & Sporobolus & neglectus & - \\
\hline Galium & pedemontanum & Narrow bedstraw & Sporobolus & ozarkanus & - \\
\hline Galium & pilosum & Hairy bedstraw & Sporobolus & vaginiflorus & Poverty-grass \\
\hline Galium & tinctorium & Marsh bedstraw & Stachys & tenuifolia & Hedge-nettle \\
\hline Galium & triflorum & Fragrant bedstraw & Staphylea & trifolia & Bladdernut \\
\hline Gaultheria & procumbens & Wintergreen & Stellaria & media & Common chickweed \\
\hline Gaura & biennis & Biennial gaura & Stellaria & pubera & Star chickweed \\
\hline Gaura & filipes & Threadstalk gaura & Stenanthium & gramineum & Featherbells \\
\hline Gaylussacia & baccata & Black huckleberry & Stipa & avenacea & Needlegrass \\
\hline Gentiana & saponaria & Soap gentian & Strophostyles & helvula & Annual woolly bean \\
\hline Gentiana & villosa & Hairy gentain & Strophostyles & umbellata & Wild bean \\
\hline Gentianella & quinquefolia & Stiff gentian & Stylophorum & diphyllum & Celandine-poppy \\
\hline Geranium & carolinianum & Carolina cranesbill & Stylosanthes & biflora & Pencil flower \\
\hline Geranium & columbinum & Longstalk crane's-bill & Symphoricarpos & orbiculatus & Coral berry \\
\hline Geranium & maculatum & Wild geranium & Taenidia & integerrima & Yellow pimpernel \\
\hline Geum & canadense & White avens & Taraxacum & officinale & Common dandelion \\
\hline Geum & vernum & Early avens & Tephrosia & spicata & Goat's rue \\
\hline Geum & virginianum & Small-flowered avens & Tephrosia & virginiana & Goat's rue \\
\hline Glechoma & hederacea & Ground-ivy & Teucrium & canadense & Woodsage \\
\hline Gleditsia & triacanthos & Honey locust & Thalictrum & dioicum & Early meadow-rue \\
\hline Glyceria & striata & Striate mannagrass & Thalictrum & revolutum & Skunk meadow-rue \\
\hline Gnaphalium & obtusifolium & Catfoot & Thalictrum & thalictroides & Rue-anemone \\
\hline Gnaphalium & purpureum & Purple cudweed & Thaspium & barbinode & Bearded meadow-parsnip \\
\hline Goodyera & pubescens & Downy rattlesnake-plantain & Thaspium & trifoliatum & Smooth meadow-parsnip \\
\hline Gratiola & neglecta & Hedge-hyssop & Thelypteris & hexagonoptera & Broad beech fern \\
\hline Gratiola & virginiana & Virginia hedge-hyssop & Thelypteris & noveboracensis & New York fern \\
\hline Hackelia & virginiana & Beggar's lice & Thelypteris & palustris & Marsh fern \\
\hline Hamamelis & virginiana & Witch-hazel & Thlaspi & perfoliatum & Thoroughwort penny-cress \\
\hline Hedeoma & pulegioides & American pennyroyal & Thuja & occidentalis & White cedar \\
\hline
\end{tabular}


Table A. (continued)

\begin{tabular}{|c|c|c|c|c|c|}
\hline Genus & Species & Common name & Genus & Species & Common name \\
\hline Hedyotis & caerulea & Bluets & Tiarella & cordifolia & Foamflower \\
\hline Hedyotis & crassifolia & - & Tilia & americana & American basswood \\
\hline Hedyotis & longifolia & Long-leaved bluets & Tipularia & discolor & Crane-fly orchid \\
\hline Hedyotis & nigricans & - & Toxicodendron & radicans & Poison ivy \\
\hline Hedyotis & nutalliana & - & Tradescantia & subaspera & Mountain spiderwort \\
\hline Hedyotis & purpurea & Woodland bluets & Tragopogon & dubius & - \\
\hline Helenium & autumnale & Autumn sneezeweed & Trichostema & brachiatum & False pennyroyal \\
\hline Helenium & flexuosum & Dark-eyed sneezeweed & Trichostema & dichotomum & Bluecurls \\
\hline Helianthus & angustifolius & Narrow-leaved sunflower & Tridens & flavus & Purple top \\
\hline Helianthus & atrorubens & Sunflower & Trifolium & campestre & Low hop-clover \\
\hline Helianthus & decapetalus & Wide-leaved sunflower & Trifolium & hybridum & Alsike clover \\
\hline Helianthus & hirsutus & Hairy sunflower & Trifolium & pratense & Red clover \\
\hline Helianthus & maximiliani & Sunflower & Trifolium & repens & White clover \\
\hline Helianthus & microcephalus & Small wood sunflower & Trillium & luteum & Yellow trillium \\
\hline Helianthus & occidentalis & Naked stemmed sunflower & Trillium & sulcatum & Trillium \\
\hline Helianthus & strumosus & Rough-leaved sunflower & Trillium & vaseyi & Vasey's trillium \\
\hline Helianthus & tuberosus & Jerusalem-artichoke & Triodanis & perfoliata & Venus' looking-glass \\
\hline Heliopsis & helianthoides & Ox-eye & Triosteum & angustifolium & Horse-gentian \\
\hline Hemerocallis & fulva & Day-lily & Tripsacum & dactyloides & Gama grass \\
\hline Hepatica & acutiloba & Sharp-lobed hepatica & Tsuga & canadensis & Hemlock \\
\hline Hepatica & americana & Round-lobed hepatica & Tussilago & farfara & Coltsfoot \\
\hline Heterotheca & camporum & Prairie golden aster & Typha & latifolia & Wideleaf cattail \\
\hline Heterotheca & graminifolia & Grass-leaved golden aster & Ulmus & alata & Winged elm \\
\hline Heterotheca & mariana & Shaggy golden aster & Ulmus & americana & American elm \\
\hline Heuchera & americana & Alumroot & Ulmus & rubra & Slippery elm \\
\hline Heuchera & villosa & Hairy alumroot & Urtica & dioica & Stinging nettle \\
\hline Hexalectris & spicata & Crested coralroot & Uvularia & grandiflora & Large-flowered bellwort \\
\hline Hexastylis & arifolia & Little brown jugs & Uvularia & perfoliata & Perfoliate bellwort \\
\hline Hibiscus & laevis & Smooth rose-mallow & Uvularia & sessiliflolia & Wild oats \\
\hline Hibiscus & moscheutos & Swamp rose-mallow & Vaccinium & arboreum & Farkleberry \\
\hline Hibiscus & trionum & Flower of an hour & Vaccinium & pallidum & Pale lowbush blueberry \\
\hline Hieracium & gronovii & Hairy hawkweed & Vaccinium & stamineum & Deerberry \\
\hline Hieracium & venosum & Rattlesnake hawkweed & Valerianella & locusta & European corn salad \\
\hline Holcus & lanatus & Velvet grass & Valerianella & radiata & Corn salad \\
\hline Holosteum & umbellatum & Jagged chickweed & Verbascum & blattaria & Moth mullein \\
\hline
\end{tabular}


Table A. (continued)

\begin{tabular}{|c|c|c|c|c|c|}
\hline Genus & Species & Common name & Genus & Species & Common name \\
\hline Hordeum & pusillum & Little barley & Verbascum & thapsus & Mullein \\
\hline Huperzia & lucidula & Shining clubmoss & Verbena & simplex & Vervain \\
\hline Hybanthus & concolor & Green violet & Verbena & urticifolia & White vervain \\
\hline Hydrangea & arborescens & Hydrangea & Verbesina & alternifolia & Wingstem \\
\hline Hydrastis & canadensis & Golden seal & Verbesina & occidentalis & Southern flatseed-sunflower \\
\hline Hydrophyllum & canadense & Maple-leaved waterleaf & Verbesina & virginica & Frostweed \\
\hline Hydrophyllum & macrophyllum & Hairy waterleaf & Vernonia & gigantea & Tall ironweed \\
\hline Hymenocallis & occidentalis & Spider lily & Veronica & agrestis & Field speedwell \\
\hline Hypericum & densiflorum & Shrubby St. John's-wort & Veronica & anagallis-aquatica & Water speedwell \\
\hline Hypericum & denticulatum & Coppery St. John's-wort & Veronica & arvensis & Corn speedwell \\
\hline Hypericum & dolabriforme & - & Veronica & hederaefolia & Ivy-leaved speedwell \\
\hline Hypericum & drummondii & Nits-and-lice & Veronica & officinalis & Common speedwell \\
\hline Hypericum & gentianoides & Pineweed & Veronica & peregrina & Speedwell \\
\hline Hypericum & gymnanthum & - & Veronica & serpyllifolia & Thyme-leaved speedwell \\
\hline Hypericum & mutilum & Dwarf St. John's-wort & Veronicastrum & virginicum & Culver's root \\
\hline Hypericum & perforatum & Common St. John's-wort & Viburnum & acerifolium & Maple-leaved virburnum \\
\hline Hypericum & prolificum & - & Viburnum & prunifolium & Smooth blackhaw \\
\hline Hypericum & punctatum & Dotted St. John's-wort & Viburnum & rufidulum & Rusty blackhaw \\
\hline Hypericum & sphaerocarpum & - & Viburnum & sp.? & Wild raisin? \\
\hline Hypericum & stragalum & - & Vicia & angustifolia & Narrow-leaved vetch \\
\hline Hypoxis & hirsuta & Yellow star grass & Vicia & caroliniana & Pale vetch \\
\hline Ilex & ambigua & Beadle's holly & Vicia & villosa & Hairy vetch \\
\hline Ilex & opaca & American holly & Vinca & minor & Periwinkle \\
\hline Ilex & verticillata & Winterberry & Viola & canadensis & Canadian violet \\
\hline Impatiens & capensis & Orange jewelweed & Viola & conspersa & Dog violet \\
\hline Impatiens & pallida & Pale jewelweed & Viola & cucullata & Marsh violet \\
\hline Ipomoea & coccinea & Scarlet morning-glory & Viola & hastata & Halbert-leaved violet \\
\hline Ipomoea & hederacea & Ivy-leaved morning-glory & Viola & hirsutula & Southern wood violet \\
\hline Ipomoea & lacunosa & Small white morning-glory & Viola & palmata & Wood-violet \\
\hline Ipomoea & pandurata & Wild potato vine & Viola & rafinesquii & Wild pansy \\
\hline Ipomoea & purpurea & Purple morning-glory & Viola & sagittata & Arrow-leaved violet \\
\hline Iris & cristata & Crested dwarf iris & Viola & sororia & Blue violet \\
\hline Iris & pseudacorus & Yellow European iris & Viola & striata & Pale violet \\
\hline Iris & virginica & Blue flag & Viola & triloba & Three-lobed violet \\
\hline Isoetes & caroliniana & Carolina quillwort & Viola & tripartita & Oval-leaved violet \\
\hline
\end{tabular}


Table A. (continued)

\begin{tabular}{|c|c|c|c|c|c|}
\hline Genus & Species & Common name & Genus & Species & Common name \\
\hline Isotria & verticillata & Whorled popgonia & Viola & tripartita & Three-parted violet \\
\hline Itea & virginica & Sweet-spire & Vitis & aestivalis & Summer grape \\
\hline Iva & annua & Rough marsh-elder & Vitis & cinerea & Downy grape \\
\hline Jeffersonia & diphylla & Twin leaf & Vitis & riparia & Frost-grape \\
\hline Juglans & nigra & Black walnut & Vitis & rotundifolia & Muscadine \\
\hline Juncus & acuminatus & Rush & Vitis & vulpina & Frost-grape \\
\hline Juncus & biflorus & Rush & Vulpia & myuros & Rat-tail fescue \\
\hline Juncus & brachycarpus & Rush & Vulpia & octoflora & Six-weeks festcue \\
\hline Juncus & brachycephalus & Rush & Waldsteinia & fragarioides & Barren strawberry \\
\hline Juncus & coriaceus & Rush & Woffia & brasiliensis & Water-meal \\
\hline Juncus & debilis & Rush & Woffia & columbiana & Water-meal \\
\hline Juncus & dudleyi & Rush & Woodsia & obtusa & Blunt-lobed woodsia \\
\hline Juncus & effusus & Soft rush & Woodwardia & areolata & Netted chain fern \\
\hline Juncus & interior & Rush & Xanthium & strumarium & Cocklebur \\
\hline Juncus & marginatus & Rush & Yucca & flaccida & Yucca \\
\hline Juncus & scirpoides & Rush & Zizia & aptera & Golden alexanders \\
\hline Juncus & secundus & Rush & Zizia & aurea & - \\
\hline Juncus & tenuis & Path rush & & & \\
\hline Juniperus & virginiana & Red cedar & & & \\
\hline Justicia & americana & Water-willow & & & \\
\hline Kalmia & latifolia & Mountain laurel & & & \\
\hline Krigia & biflora & Dwarf dandelion & & & \\
\hline
\end{tabular}



APPENDIX B

ANIMALS FOUND ON THE OAK RIDGE RESERVATION 

Table B.1. Fishes on the Oak Ridge Reservation ${ }^{a}$

\begin{tabular}{|c|c|c|}
\hline Family & Genus and species & Common name \\
\hline Petromyzontidae & Ichthyomyzon castaneus Girard & Chestnut lamprey \\
\hline Polyodontidae & Polyodon spathula (Walbaum) & Paddlefish \\
\hline Lepisosteidae & Lepisosteus oculatus Winchell & Spotted gar \\
\hline Hiodontidae & Hiodon tergisus Lesueur & Mooneye \\
\hline Clupeidae & Alosa chrysochloris (Rafinesque) & Skipjack herring \\
\hline Clupeidae & A. pseudoharengus (Wilson) & Alewife \\
\hline Clupeidae & Dorosoma cepedianum (Lesueur) & Gizzard shad \\
\hline Clupeidae & D. petenense (Gunther) & Threadfin shad \\
\hline Cyprinidae & Campostoma oligolepis Hubbs \& Greene & Largescale stoneroller \\
\hline Cyprinidae & Carassius auratus (Linnaeus) & Goldfish \\
\hline Cyprinidae & Ctenopharyngodon idella (Valenciennes) & Grass carp \\
\hline Cyprinidae & Cyprinella spiloptera (Cope) & Spotfin shiner \\
\hline Cyprinidae & C. whipplei Girard & Steelcolor shiner \\
\hline Cyprinidae & Cyprinus carpio Linnaeus & Carp \\
\hline Cyprinidae & Erimonax monachus ${ }^{c}$ (Cope) & Spotfin chub \\
\hline Cyprinidae & Hybopsis amblops (Rafinesque) & Bigeye chub \\
\hline Cyprinidae & Luxilus chrysocephalus Rafinesque & Striped shiner \\
\hline Cyprinidae & Lythrurus ardens (Cope) & Rosefin shiner \\
\hline Cyprinidae & Notemigonus crysoleucas (Mitchill) & Golden shiner \\
\hline Cyprinidae & Notropis atherinoides Rafinesque & Emerald shiner \\
\hline Cyprinidae & Phoxinus tennesseensis Starnes \& Jenkins & Tennessee dace \\
\hline Cyprinidae & Pimephales notatus (Rafinesque) & Bluntnose minnow \\
\hline Cyprinidae & P. promelas Rafinesque & Fathead minnow \\
\hline Cyprinidae & Semotilus atromaculatus (Mitchill) & Creek chub \\
\hline Catostomidae & Carpiodes carpio (Rafinesque) & River carpsucker \\
\hline Catostomidae & C. cyprinus (Lesueur) & Quillback \\
\hline Catostomidae & Catostomus commersoni (Lacepede) & White sucker \\
\hline
\end{tabular}


Table B.1. (continued)

\begin{tabular}{|c|c|c|}
\hline Family & Genus and species & Common name \\
\hline Catostomidae & Hypentelium nigricans (Lesueur) & Northern hog sucker \\
\hline Catostomidae & Ictiobus bubalus (Rafinesque) & Smallmouth buffalo \\
\hline Catostomidae & I. niger (Rafinesque) & Black buffalo \\
\hline Catostomidae & Minytrema melanops (Rafinesque) & Spotted sucker \\
\hline Catostomidae & Moxostoma anisurum (Rafinesque) & Silver redhorse \\
\hline Catostomidae & M. duquesnei (Lesueur) & Black redhorse \\
\hline Catostomidae & M. erythrurum (Rafinesque) & Golden redhorse \\
\hline Ictaluridae & Ameiurus melas (Rafinesque) & Black bullhead \\
\hline Ictaluridae & A. natalis (Lesueur) & Yellow bullhead \\
\hline Ictaluridae & Ictalurus furcatus (Lesueur) & Blue catfish \\
\hline Ictaluridae & I. punctatus (Rafinesque) & Channel catfish \\
\hline Ictaluridae & Pylodictis olivaris (Rafinesque) & Flathead catfish \\
\hline Esocidae & Esox lucius Linnaeus & Northern pike \\
\hline Esocidae & E. masquinongy Mitchill & Muskellunge \\
\hline Atherinidae & Labidesthes sicculus (Cope) & Brook silverside \\
\hline Poeciliidae & Gambusia affinis (Baird and Girard) & Mosquitofish \\
\hline Gasterosteidae & Culaea inconstans (Kirtland) & Brook stickleback \\
\hline Cottidae & Cottus carolinae (Gill) & Banded sculpin \\
\hline Percichthyidae & Morone chrysops (Rafinesque) & White bass \\
\hline Percichthyidae & M. mississippiensis Jordan and Eigenmann & Yellow bass \\
\hline Percichthyidae & M. saxatilis (Walbaum) & Striped bass \\
\hline Centrarchidae & Ambloplites rupestris (Rafinesque) & Rock bass \\
\hline Centrarchidae & Lepomis auritus (Linneaus) & Redbreast sunfish \\
\hline Centrarchidae & L. cyanellus Rafinesque & Green sunfish \\
\hline Centrarchidae & L. gulosus (Cuvier) & Warmouth \\
\hline Centrarchidae & L. macrochirus Rafinesque & Bluegill \\
\hline Centrarchidae & L. megalotis (Rafinesque) & Longear sunfish \\
\hline Centrarchidae & L. microlophus (Gunther) & Redear sunfish \\
\hline Centrarchidae & Micropterus dolomieu Lacepede & Smallmouth bass \\
\hline Centrarchidae & M. punctulatus (Rafinesque) & Spotted bass \\
\hline
\end{tabular}


Table B.1. (continued)

\begin{tabular}{lll}
\hline \multicolumn{1}{c}{ Family } & \multicolumn{1}{c}{ Genus and species } & \multicolumn{1}{c}{ Common name } \\
\hline Centrarchidae & M. salmoides (Lacepede) & Largemouth bass \\
Centrarchidae & Pomoxis annularis Rafinesque & White crappie \\
Centrarchidae & P. nigromaculatus (Lesueur) & Black crappie \\
Percidae & Etheostoma blennioides Rafinesque & Greenside darter \\
Percidae & E. duryi Henshall & Blackside snubnose \\
& & darter \\
Percidae & E. jessiae (Jordan \& Brayton) & Blueside darter \\
Percidae & E. kennicotti (Putnam) & Stripetail darter \\
Percidae & E. rufilineatum (Cope) & Redline darter \\
Percidae & E. simoterum (Cope) & Snubnose darter \\
Percidae & Perca flavescens (Mitchill) & Yellow perch \\
Percidae & Percina caprodes (Rafinesque) & Logperch \\
Percidae & P. sciera (Swain) & Dusky darter \\
Percidae & Sander canadense (Griffith \& Smith) & Sauger \\
Percidae & S. vitreus (Mitchill) & Walleye \\
Sciaenidae & Aplodinotus grunniens (Rafinesque) & Freshwater drum \\
\hline
\end{tabular}

${ }^{a}$ Based on "A Checklist of Fishes on the Department of Energy Oak Ridge Reservation," Michael G. Ryon and James M. Loar, Oak Ridge National Laboratory, Journal of the Tennessee Academy of Science, Vol. 63, Number 4, October 1988, updates by M. G. Ryon, August 2006.

${ }^{b}$ Taxonomic classifications and names based on J. S. Nelson, E. J. Crossman, H. Espinosa-Perez, L. T. Findley, C. R. Gilbert, R. N. Lea, and J. D. Williams, Common and Scientific Names of Fishes from the United States, Canada, and Mexico, American Fisheries Society, Special Publication 29, Bethesda, Maryland, 2004.

${ }^{c}$ Specimen was collected in section of East Fork Poplar Creek in Oak Ridge, Tennessee, between two parcels of the Oak Ridge Reservation. 
Table B.2. Reptiles, amphibians, and mammals on the

Oak Ridge Reservation

\begin{tabular}{|c|c|}
\hline Common name & Scientific name \\
\hline \multicolumn{2}{|c|}{ Reptiles and amphibians } \\
\hline Spotted salamander & Ambystoma maculatum \\
\hline Marbled salamander & Ambystoma opacum \\
\hline Eastern tiger salamander & Ambystoma tigrinum \\
\hline Red spotted newt & Notophthalmus viridescens \\
\hline Dusky salamander & Desmognathus fuscus \\
\hline Two-lined salamander & Eurycea bislineata \\
\hline Longtail salamander & Eurycea longicauda \\
\hline Cave salamander & Eurycea lucifuga \\
\hline Spring salamander & Gyrinophilus porphyriticus \\
\hline Slimy salamander & Plethodon glutinosus \\
\hline Four-toed salamander & Hemidactylium scutatum \\
\hline Red salamander & Pseudotriton ruber \\
\hline Eastern spadefoot toad & Scaphiopus holbrookii \\
\hline American toad & Bufo americanus \\
\hline Spring peeper & Pseudacris crucifer \\
\hline Gray treefrog & Hyla versicolor \\
\hline Eastern narrow mouth toad & Gastrophryne carolinensis \\
\hline Chorus frog & Pseudacris triseriata \\
\hline Bull frog & Rana catesbeiana \\
\hline Green frog & Rana clamitans \\
\hline Southern leopard frog & Rana utricularia \\
\hline Snapping turtle & Chelydra serpentina \\
\hline Stripeneck musk turtle & Sternotherus minor \\
\hline Stinkpot & Sternotherus odoratus \\
\hline Eastern box turtle & Terrapene carolina \\
\hline Map turtle & Graptemys geographica \\
\hline Painted turtle & Chrysemys picta \\
\hline Red-eared slider & Trachemys scripta elegans \\
\hline Cumberland slider & Trachemys scripta troosti \\
\hline Spinny softshell & Apalone spinifra \\
\hline Fence lizard & Sceloporus undulatus \\
\hline Six-lined racerunner & Cnemidophorus sexlineatus \\
\hline Ground skink & Scincella lateralis \\
\hline Five-lined skink & Eumeces fasciatus \\
\hline Worm snake & Carphophis amoenus \\
\hline
\end{tabular}


Table B.2. (continued)

\begin{tabular}{|c|c|}
\hline Common name & Scientific name \\
\hline Black racer & Coluber constrictor \\
\hline Ringneck snake & Diadophis punctatus \\
\hline Corn snake & Elaphe guttata \\
\hline Rat snake & Elaphe obsolete \\
\hline Black kingsnake & Lampropeltis getula \\
\hline Northern water snake & Nerodia sipedon \\
\hline Brown snake & Storeria dekayi \\
\hline Eastern garter snake & Thamnophis sirtalis \\
\hline Smooth earth snake & Virginia valeriae \\
\hline Copperhead & Agkistrodon contortrix \\
\hline \multicolumn{2}{|c|}{ Mammals } \\
\hline Opposum & Didelphis virginiana \\
\hline Southeastern shrew $^{a}$ & Sorex longirostris \\
\hline Shorttailed shrew & Blarina brevicauda \\
\hline Least shrew & Cryptotis parva \\
\hline Eastern mole & Scalopus aquaticus \\
\hline Gray bat ${ }^{b}$ & Myotis grisescens \\
\hline Eastern pipistrelle & Pipistrellus subflavus \\
\hline Silver-haired bat & Lasionycteris noctivagans \\
\hline Big brown bat & Eptesicus fuscus \\
\hline Eastern red bat & Lasiurus borealis \\
\hline Evening bat & Nycticeius humeralis \\
\hline Eastern cottontail & Sylvilagus floridanus \\
\hline Eastern chipmunk & Tamias striatus \\
\hline Groundhog & Marmota monax \\
\hline Eastern gray squirrel & Sciurus carolinensis \\
\hline Southern flying squirrel & Glaucomys volans \\
\hline Beaver & Castor canadensis \\
\hline Eastern harvest mouse & Reithrodontomys humulis \\
\hline White-footed mouse & Peromyscus leucopus \\
\hline Golden mouse & Peromyscus nuttalli \\
\hline Deer mouse & Peromyscus maniculatus \\
\hline Hispid cotton rat & Sigmodon hispidus \\
\hline Pine vole & Pitymys pinetorum \\
\hline Meadow vole & Microtus pennsylvanicus \\
\hline Muskrat & Ondatra zibethica \\
\hline Norway rat & Rattus norvegicus \\
\hline
\end{tabular}


Table B.2. (continued)

\begin{tabular}{ll}
\hline \multicolumn{1}{c}{ Common name } & \multicolumn{1}{c}{ Scientific name } \\
\hline House mouse & Mus musculus \\
Coyote & Canis latrans \\
Red fox & Vulpes vulpes \\
Gray fox & Urocyon cinereoargenteus \\
Raccoon & Procyon lotor \\
Mink & Mustela vison \\
Striped skunk & Mephitis mephitis \\
Whitetailed deer & Odocoileus virginianus \\
Elk & Cervus canadensis \\
\hline \multicolumn{2}{c}{${ }^{a}$ Deemed by state as in need of management. }
\end{tabular}

Table B.3. Birds on the Oak Ridge Reservation

\begin{tabular}{|c|c|c|c|}
\hline Common name & Scientific name & Presence & Status \\
\hline \multicolumn{4}{|c|}{ Loons } \\
\hline Common loon & Gavia immer & Winter & \\
\hline \multicolumn{4}{|c|}{ Grebes } \\
\hline Pied-billed grebe & Podilymbus podiceps & Casual visitor & \\
\hline Horned grebe & Podiceps auritus & Winter & \\
\hline Eared grebe & Podiceps nigricollis & Transient & \\
\hline \multicolumn{4}{|c|}{ Cormorants } \\
\hline Double-crested cormorant & Phalacrocorax auritus & Casual visitor & \\
\hline \multicolumn{4}{|c|}{ Darters } \\
\hline Anhinga & Anhinga anhinga & Transient & NM \\
\hline \multicolumn{4}{|c|}{ Bitterns and herons } \\
\hline Great blue heron & Ardea herodias & Breeder & \\
\hline Great egret & Ardea alba & Casual visitor & NM \\
\hline Snowy egret & Egretta thula & Migrant & NM \\
\hline Little blue heron & Egretta caerulea & Casual visitor & NM \\
\hline Green heron & Butorides virescens & Breeder & \\
\hline Black-crowned night-heron & $\begin{array}{l}\text { Nycticorax nycticorax } \\
\text { Swans, geese, and ducks }\end{array}$ & Breeder & \\
\hline Mute swan & Cygnus olor & Casual visitor & \\
\hline Canada goose & Anser canadensis & Breeder & \\
\hline Ross' goose & Chen rossii & Migrant & \\
\hline Snow goose & Chen caerulescens & Migrant & \\
\hline Greater white-fronted goose & Anser albifrons & Migrant & \\
\hline Wood duck & Aix sponsa & Breeder & \\
\hline Green-winged teal & Anas crecca & Winter & \\
\hline American black duck & Anas rubripes & Winter & \\
\hline Mallard & Anas platyrhynchos & Breeder & \\
\hline
\end{tabular}


Table B.3. (continued)

\begin{tabular}{|c|c|c|c|}
\hline Common name & Scientific name & Presence & Status \\
\hline Northern pintail & Anas acuta & Winter & \\
\hline Blue-winged teal & Anas discors & Winter & \\
\hline Gadwall & Anas strepera & Winter & \\
\hline American wigeon & Anas americana & Winter & \\
\hline Northern shoveler & Anas clypeata & Winter & \\
\hline Canvasback & Aythya valisineria & Winter & \\
\hline Ring-necked duck & Aythya collaris & Winter & \\
\hline Greater scaup & Aythya marila & Winter & \\
\hline Lesser scaup & Aythya affinis & Winter & \\
\hline Bufflehead & Bucephala clangula & Winter & \\
\hline Hooded merganser & Lophodytes cucullatus & Winter & \\
\hline Red-breasted merganser & Mergus serrator & Winter & \\
\hline Common merganser & Mergus merganser & Winter & \\
\hline Ruddy duck & $\begin{array}{c}\text { Oxyura jamaicensus } \\
\text { Vultures }\end{array}$ & Winter & \\
\hline Black vulture & Coragyps atratus & Breeder & \\
\hline \multirow[t]{2}{*}{ Turkey vulture } & Cathartes aura & Breeder & \\
\hline & Kites, hawks, eagles, and allies & & \\
\hline Osprey & Pandion haliaetus & Breeder & \\
\hline Bald eagle & Haliaeetus leucocephalus & Casual visitor & FT, NM \\
\hline Northern harrier & Circus cyaneus & Winter & NM \\
\hline Sharp-shinned hawk & Accipiter striatus & Possible breeder & NM \\
\hline Cooper's hawk & Accipiter cooperii & Possible breeder & \\
\hline Red-shouldered hawk & Buteo lineatus & Breeder & \\
\hline Red-tailed hawk & Buteo jamaicensis & Breeder & \\
\hline \multirow[t]{2}{*}{ Broad-winged hawk } & Buteo platypterus & Breeder & \\
\hline & Falcons & & \\
\hline American kestrel & Falco sparverius & Breeder & \\
\hline \multirow[t]{2}{*}{ Peregrine falcon } & Falco peregrinus & Migrant & SE \\
\hline & Grouse, turkey, and quail & & \\
\hline Ruffed grouse & Bonasa umbellus & Casual visitor & \\
\hline Wild turkey & Meleagris gallopavo & Breeder & \\
\hline Northern bobwhite & $\begin{array}{l}\text { Colinus virginianus } \\
\text { Rails and coots }\end{array}$ & Breeder & \\
\hline Sora & Porzana carolina & Migrant & \\
\hline \multirow[t]{2}{*}{ American coot } & Fulica americana & Casual visitor & \\
\hline & Cranes & & \\
\hline \multirow[t]{2}{*}{ Sandhill crane } & Grus canadensis & Migrant & \\
\hline & Plovers & & \\
\hline Killdeer & Charadrius vociferus & Breeder & \\
\hline \multirow[t]{2}{*}{ Semipalmated plover } & Charadrius semipalmatus & Migrant & \\
\hline & Sandpipers and allies & & \\
\hline Greater yellowlegs & Tringa melanoleuca & Migrant & \\
\hline Lesser yellowlegs & Tringa flavipes & Migrant & \\
\hline Solitary sandpiper & Tringa solitaria & Migrant & \\
\hline Spotted sandpiper & Actitus macularius & Casual visitor & \\
\hline
\end{tabular}


Table B.3. (continued)

\begin{tabular}{|c|c|c|c|}
\hline Common name & Scientific name & Presence & Status \\
\hline Pectoral sandpiper & Calidris melanotos & Migrant & \\
\hline White-rumped sandpiper & Calidris fuscicollis & Migrant & \\
\hline Least sandpiper & Calidris minutilla & Migrant & \\
\hline Common snipe & Gallinago gallinago & Winter & \\
\hline American woodcock & Scolopax minor & Breeder & \\
\hline \multicolumn{4}{|c|}{ Gulls and terns } \\
\hline Bonaparte's gull & Larus philadelphia & Winter & \\
\hline Ring-billed gull & Larus delawarensis & Winter & \\
\hline Caspian tern & Sterna caspia & Transient & \\
\hline Forster's tern & Sterna forsteri & Transient & \\
\hline \multicolumn{4}{|c|}{ Pigeons and doves } \\
\hline Rock pigeon & Columba livia & Breeder & \\
\hline Mourning dove & Zenaida macroura & Breeder & \\
\hline \multicolumn{4}{|c|}{ Cuckoos } \\
\hline Yellow-billed cuckoo & Coccyzus americanus & Breeder & \\
\hline \multicolumn{4}{|c|}{ Owls } \\
\hline Northern saw-whet owl & Aegolius acadicus & Transient & \\
\hline Eastern screech-owl & Megascops asio & Breeder & \\
\hline Great horned owl & Bubo virginianus & Breeder & \\
\hline Barred owl & Strix varia & Breeder & \\
\hline Barn owl & Tyto alba & Possible breeder & NM \\
\hline \multicolumn{4}{|c|}{ Goatsuckers } \\
\hline Common nighthawk & Chordeiles minor & Breeder & \\
\hline Chuck-will's-widow & Caprimulgus carolinensis & Breeder & $\mathrm{C}$ \\
\hline \multicolumn{4}{|c|}{ Swifts } \\
\hline Chimney swift & Chaetura pelagica & Breeder & \\
\hline Ruby-throated hummingbird & Archilochus colubris & Breeder & \\
\hline \multicolumn{4}{|c|}{ Kingfishers } \\
\hline Belted kingfisher & Ceryle alcyon & Breeder & \\
\hline \multicolumn{4}{|c|}{ Woodpeckers } \\
\hline Red-bellied woodpecker & Melanerpes carolinus & Breeder & \\
\hline Red-headed woodpecker & Melanerpes erythrocephalus & Breeder & \\
\hline Yellow-bellied sapsucker & Sphyrapicus varius & Winter & NM \\
\hline Downy woodpecker & Picoides pubescens & Breeder & \\
\hline Hairy woodpecker & Picoides vollosus & Breeder & \\
\hline Northern flicker & Colaptes auratus & Breeder & \\
\hline Pileated woodpecker & Dryocopus pileatus & Breeder & \\
\hline \multicolumn{4}{|c|}{ Tyrant flycatchers } \\
\hline Olive-sided flycatcher & Contopus cooperi & Migrant & NM \\
\hline Eastern wood-pewee & Contopus virens & Breeder & \\
\hline Acadian flycatcher & Empidonax virescens & Breeder & \\
\hline Willow flycatcher & Empidonax trailii & Breeder & \\
\hline Eastern phoebe & Sayornis phoebe & Breeder & \\
\hline
\end{tabular}


Table B.3. (continued)

\begin{tabular}{|c|c|c|c|}
\hline Common name & Scientific name & Presence & Status \\
\hline Great crested flycatcher & Myiarchus crinitus & Breeder & \\
\hline Eastern kingbird & Tyrannus tyrannus & Breeder & \\
\hline Western kingbird & Tyrannus verticalis & Transient & \\
\hline \multicolumn{4}{|c|}{ Larks } \\
\hline \multicolumn{4}{|c|}{ Swallows } \\
\hline Purple martin & Progne subis & Breeder & \\
\hline Tree swallow & Tachycineta bicolor & Breeder & \\
\hline Northern rough-winged swallow & Stelgidopteryx serripennis & Breeder & \\
\hline Cliff swallow & Petrochelidon fulva & Breeder & \\
\hline Barn swallow & Hirundo rustica & Breeder & \\
\hline \multicolumn{4}{|c|}{ Jays and crows } \\
\hline Blue jay & Cyannocitta cristata & Breeder & \\
\hline \multicolumn{4}{|c|}{ Titmice and chickadees } \\
\hline Carolina chickadee & Poecile carolinensis & Breeder & \\
\hline \multicolumn{4}{|c|}{ Nuthatches } \\
\hline Red-breasted nuthatch & Sitta canadensis & Winter & \\
\hline White-breasted nuthatch & Sitta carolinensis & Breeder & \\
\hline Brown-headed nuthatch & Sitta pusilla & Breeder & $\mathrm{C}$ \\
\hline \multicolumn{4}{|c|}{ Creepers } \\
\hline \multicolumn{4}{|c|}{ Wrens } \\
\hline Carolina wren & Thryothorus ludovicianus & Breeder & \\
\hline House wren & Troglodytes aedon & Breeder & \\
\hline Winter wren & Troglodytes troglodytes & Winter & \\
\hline Sedge wren & Cistothorus platensis & Migrant & \\
\hline Marsh wren & Cistothorus palustris & Migrant & \\
\hline \multicolumn{4}{|c|}{ Kinglets, gnatcatchers, and thrushes } \\
\hline Golden-crowned kinglet & Regulus satrapa & Winter & \\
\hline Ruby-crowned kinglet & Regulus calendula & Winter & \\
\hline Blue-gray gnatcatcher & Polioptila caerulea & Breeder & \\
\hline Eastern bluebird & Siala sialis & Breeder & \\
\hline Veery & Catharus fuscescens & Migrant & \\
\hline Swainson's thrush & Catharus ustulatus & Migrant & \\
\hline Hermit thrush & Catharus guttatus & Winter & \\
\hline Wood thrush & Hylocichla mustelina & Breeder & $\mathrm{C}$ \\
\hline American robin & Turdus migratorius & Breeder & \\
\hline Varied thrush & Ixoreus naevius & Transient & \\
\hline \multicolumn{4}{|c|}{ Pipits and wagtails } \\
\hline American pipit & Anthus rubescens & Migrant & \\
\hline \multicolumn{4}{|c|}{ Thrashers and mockingbirds } \\
\hline Gray catbird & Dumetella carolinensis & Breeder & \\
\hline
\end{tabular}


Table B.3. (continued)

\begin{tabular}{|c|c|c|c|}
\hline Common name & Scientific name & Presence & Status \\
\hline Northern mockingbird & Mimus polyglottos & Breeder & \\
\hline Brown thrasher & $\begin{array}{r}\text { Toxostoma rufum } \\
\text { Waxwings }\end{array}$ & Breeder & \\
\hline Cedar waxwing & $\begin{array}{c}\text { Bombycilla cedrorum } \\
\text { Shrikes }\end{array}$ & Breeder & \\
\hline Loggerhead shrike & $\begin{array}{c}\text { Lanius ludovicianus } \\
\text { Starlings }\end{array}$ & Transient & NM \\
\hline European starling & $\begin{array}{r}\text { Sturnus vulgaris } \\
\text { Vireos }\end{array}$ & Breeder & \\
\hline White-eyed vireo & Vireo griseus & Breeder & \\
\hline Blue-headed vireo & Vireo solitarius & Migrant & \\
\hline Yellow-throated vireo & Vireo flavifrons & Breeder & \\
\hline Red-eyed vireo & Vireo olivaceus & Breeder & \\
\hline Warbling vireo & $\begin{array}{l}\text { Vireo gilvus } \\
\text { Wood warblers }\end{array}$ & Casual visitor & \\
\hline Blue-winged warbler & Vermivora pinus & Breeder & $\mathrm{C}$ \\
\hline Golden-winged warbler & Vermivora chrysotera & Migrant & $\mathrm{NM}, \mathrm{C}$ \\
\hline Tennessee warbler & Vermivora peregrina & Migrant & \\
\hline Nashville warbler & Vermivora ruficapilla & Migrant & \\
\hline Northern parula & Parula americana & Breeder & \\
\hline Yellow warbler & Dendroica petechia & Breeder & \\
\hline Chestnut-sided warbler & Dendroica pensylvanica & Migrant & \\
\hline Magnolia warbler & Dendroica magnolia & Migrant & \\
\hline Cape May warbler & Dendroica tigrina & Migrant & \\
\hline Black-throated blue warbler & Dendroica caerulescens & Migrant & $\mathrm{C}$ \\
\hline Yellow-rumped warbler & Dendroica coronata & Winter & \\
\hline Black-throated green warbler & Dendroica virens & Possible breeder & \\
\hline Blackburnian warbler & Dendroica fusca & Migrant & \\
\hline Yellow-throated warbler & Dendroica dominica & Breeder & \\
\hline Pine warbler & Dendroica pinus & Breeder & \\
\hline Prairie warbler & Dendroica discolor & Breeder & $\mathrm{C}$ \\
\hline Palm warbler & Dendroica palmarum & Migrant & \\
\hline Bay-breasted warbler & Dendroica castanea & Migrant & \\
\hline Blackpoll warbler & Dendroica striata & Migrant & \\
\hline Cerulean warbler & Dendroica cerulea & Possible breeder & $\mathrm{NM}, \mathrm{C}$ \\
\hline Black-and-white warbler & Mniotilta varia & Possible breeder & \\
\hline American redstart & Setophaga ruticilla & Possible breeder & \\
\hline Prothonotary warbler & Protonotaria citrea & Breeder & $\mathrm{C}$ \\
\hline Worm-eating warbler & Helmitheros vermivorus & Breeder & $\mathrm{C}$ \\
\hline Ovenbird & Seiurus aurocapillus & Breeder & \\
\hline Northern waterthrush & Seiurus novaboracensus & Migrant & \\
\hline Louisiana waterthrush & Seiurus motacilla & Possible breeder & $\mathrm{C}$ \\
\hline Kentucky warbler & Oporornis formosus & Breeder & $\mathrm{C}$ \\
\hline Common yellowthroat & Geothlypis trichas & Breeder & \\
\hline Hooded warbler & Wilsonia citrina & Breeder & \\
\hline Wilson's warbler & Wilsonia pusilla & Migrant & \\
\hline
\end{tabular}


Table B.3. (continued)

\begin{tabular}{|c|c|c|c|}
\hline Common name & Scientific name & Presence & Status \\
\hline Canada warbler & Wilsonia canadensis & Migrant & \\
\hline Yellow-breasted chat & Icteria virens & Breeder & \\
\hline \multicolumn{4}{|c|}{ Tanagers } \\
\hline Summer tanager & Piranga rubra & Breeder & \\
\hline Scarlet tanager & Piranga olivacea & Breeder & \\
\hline \multicolumn{4}{|c|}{ Cardinals, grosbeaks, and allies } \\
\hline Northern cardinal & Cardinalis cardinalis & Breeder & \\
\hline Rose-breasted grosbeak & Pheucticus ludovicianus & Migrant & \\
\hline Blue grosbeak & Passerina caerulea & Breeder & \\
\hline Indigo bunting & Passerina cyanea & Breeder & \\
\hline Dickcissel & Spiza americana & Casual visitor & \\
\hline \multicolumn{4}{|c|}{ Towhees, sparrows, and allies } \\
\hline Eastern towhee & Pipilo erythrophthalmus & Breeder & \\
\hline American tree sparrow & Spizella arborea & Winter & \\
\hline Chipping sparrow & Spizella passerina & Breeder & \\
\hline Field sparrow & Spizella pusilla & Breeder & $\mathrm{C}$ \\
\hline Savannah sparrow & Passerculus sandwichensis & Migrant+winter & \\
\hline Grasshopper sparrow & Ammodramus savannarum & Breeder & \\
\hline Fox sparrow & Passerella iliaca & Winter & \\
\hline Song sparrow & Melospiza melodia & Breeder & \\
\hline Swamp sparrow & Melospiza georgiana & Winter & \\
\hline White-throated sparrow & Zonotrichia albicollis & Winter & \\
\hline White-crowned sparrow & Zonotrichia leucophrys & Migrant & \\
\hline Vesper sparrow & Pooecetes gramineus & Migrant & NM \\
\hline Dark-eyed junco & Junco hyemalis & Winter & \\
\hline \multicolumn{4}{|c|}{ Blackbirds and allies } \\
\hline Bobolink & Dolichonyx oryzivorus & Migrant & \\
\hline Red-winged blackbird & Agelaius phoeniceus & Breeder & \\
\hline Eastern meadowlark & Sturnella magna & Breeder & \\
\hline Common grackle & Quiscalus quiscula & Breeder & \\
\hline Brown-headed cowbird & Molothrus ater & Breeder & \\
\hline Orchard oriole & Icterus spurius & Breeder & \\
\hline Baltimore oriole & Icterus galbula & Breeder & \\
\hline \multicolumn{4}{|c|}{ Finches } \\
\hline Purple finch & Carpodacus purpureus & Winter & \\
\hline House finch & Carpodacus mexicanus & Breeder & \\
\hline Pine siskin & Carduelis pinus & Migrant & \\
\hline American goldfinch & Carduelis tristis & Breeder & \\
\hline Evening grosbeak & Coccothraustes vespertinus & Migrant & \\
\hline \multicolumn{4}{|c|}{ Old world sparrows } \\
\hline House sparrow & Passer domesticus & Breeder & \\
\hline
\end{tabular}

$\mathrm{C}=$ Partners in Flight-designated birds of concern.

$\mathrm{FT}=$ Federally threatened.

$\mathrm{NM}=$ Deemed by the state as in need of management.

$\mathrm{SE}=$ State endangered. 



\section{INTERNAL DISTRIBUTION}

1.

2.

3.

4.

5.

6.

7.

8.

9.

10.

11.

12.

13.

14.

15.

16.

17.

18.

19.

20.

21.

22.

23.

24.

25.

26. ORNL Laboratory Records (RC)

\section{EXTERNAL DISTRIBUTION}

27.

28.

29. 